\title{
LEGBILY'
}

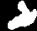
A
major
purpose
of
the

Technical Information Center is to provide the broadest dissemination possible of information contained in DOE's Research and Development Reports to business, industry, the academic community, and federal, state and local governments.

Although portions of this report are not reproducible, it is being made available in microfiche to facilitate the availability of those parts of the document which are legible.

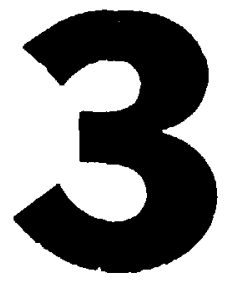




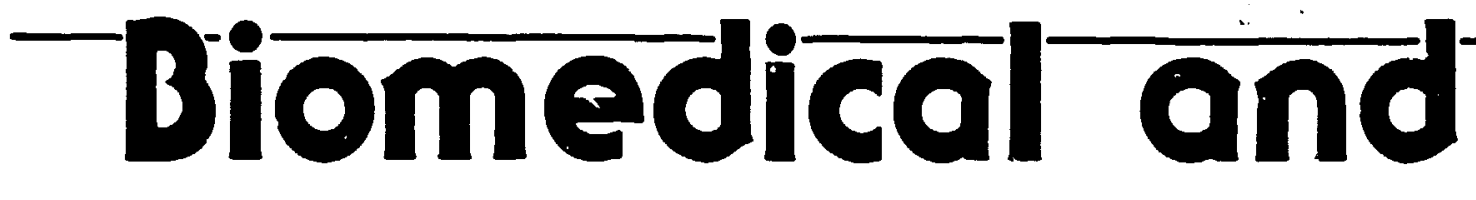

Environmental

Sciences

-Program

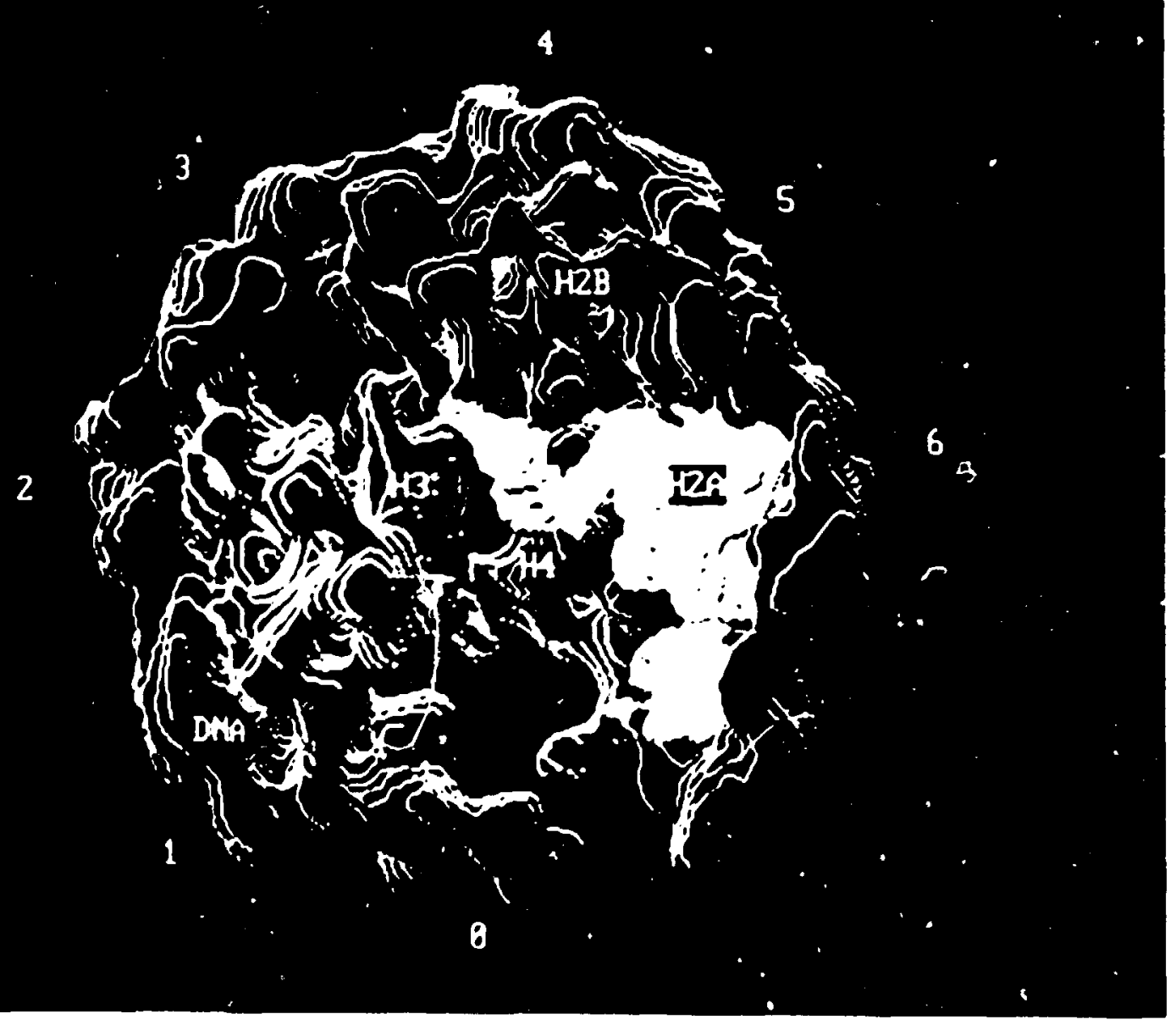

Oak Ridge National Laboratory 
This report was prepared as an account of work sponsored by an agency of the United Siates Government Neither the United States Government nor any agency thereol no: any of theif employees. makes any warrenty. express or implied. or assumes any legal liability or responsibility for ine accuracy completeness. or usafulness of any informution. apparatus. product. or process disclos of or represenis that ils use would not infringe privateiy ownod rights Reterence nerein to any specilic commercial product. process. or senvice by trade name. Irademark manufacturer or otherwise. does not necessafily constitute or imply its endorsement. reccmmendotion. or lavoring by the Unitsd States Government or any agency inereot The views and opinions of authors expressed herein do nol necessarily state or reflect inose of the United States Government or any agency inereol

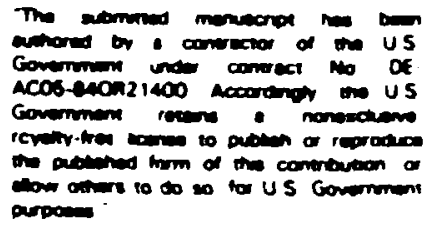

Cover: The nucleosome is the fundamental structural and functional element of the genome. This nucleoprotein complex consists of pairs of the histones $\mathrm{H} 2 \mathrm{~A}, \mathrm{H} 2 \mathrm{~B}, \mathrm{H} 3$, $\mathrm{H} 4$ and approximately 146 hase pairs of duplex DNA. The X-ray crystal structure of the nucleosome has been solved by a group at ORNL to $8 \mathrm{~A}$ resolution. This figures shows a portion of the nucleosome core particle viewed along the DNA superhelical axis. The structure contains the longest segment of continuous double-stranded DNA observed at molecular resolution and is the only crystallized DNA with a highly curved path as in the genome. The upper gyre of DNA is aimost entirely shown, running frem base pair 73 at position zero around to the DNA end at about the 5 o'cleck position. The portion of histone shown contairis virtually all of the upper $\mathrm{H} 3$ (blue) and $\mathrm{H} 4$ (green) with a hint of the lower $\mathrm{H} 3$ and $\mathrm{H} 4$ also visible. $\mathrm{H} 4$ has a very tight contact with the CNA near position +3 and even appears to protrude between the DNA gyres. From this location, $\mathrm{H} 4$ extends across toward the $40^{\prime}$ clock position. $\mathrm{H} 3$ interarts with DNA from pos tion 0 to about $+21 / 2$ and extends out towards the viewer higher than the adjacent DNA. Only small portions of $\mathrm{H} 2 \mathrm{~A}$ (violet) and $\mathrm{H} 2 \mathrm{~B}$ (red) are shown. In subsequent sections, the $\mathrm{H} 2 \mathrm{~B}$ density extends from about position +5 to +3 . The $\mathrm{H} 2 \mathrm{~A}$ density extends from where visible into the central region of the figure. (Counesy of $G$ J. Bunick and $E$. C. Uberbacher) 
ORNL / M- -560

DE88 012148

\section{Biomedical and Environmental Sciences Programs at the Oak Ridge National Laboratory}

C. R. Rishmond, Associate Director Biomedical and Environmental Sciences

C. A. Johnson, Technical Assistant

February 1988

Prenared for the

Ofrice of Health and Environmental Research

Office of Enstgy Research

U.S. Department of Energy

by the

OAK RIDGE NATIONAL LABORATORY

Oak Ridge. Tennessee 37831 operated by

MARTIN MARIETTA ENERGY SYSTEMS, INC.

for the

U.S. Department of Energy

under Contract No. DE-ACOS-84OR21 400 
List of Figures $\quad \ldots \ldots \ldots \ldots$

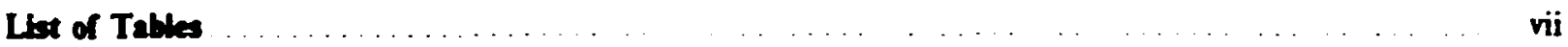

Acknowled

Rove . . . . . . . . . .

Overview . . . . . . . . . . . . . . . . . . 1

Mission of the ORNL Biomedical and Esvironmental Sciences Program $\ldots \ldots \ldots \ldots \ldots \ldots$

Mission of Oak Ridge National Laboratory $\ldots \ldots \ldots \ldots \ldots \ldots \ldots \ldots \ldots \ldots \ldots \ldots \ldots \ldots \ldots$

Missions of the DOE Multiprogram National Laboratories $\ldots \ldots \ldots \ldots \ldots \ldots \ldots \ldots \ldots \ldots$

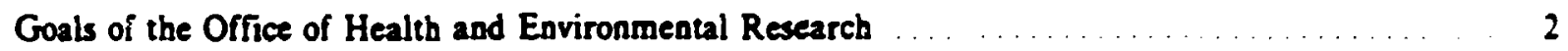

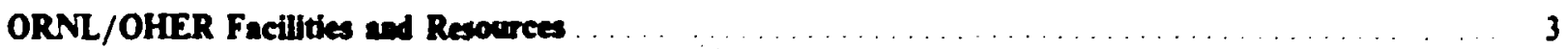

Research Managemeat Practices $\ldots \ldots \ldots \ldots \ldots \ldots \ldots \ldots \ldots \ldots \ldots \ldots \ldots \ldots \ldots$

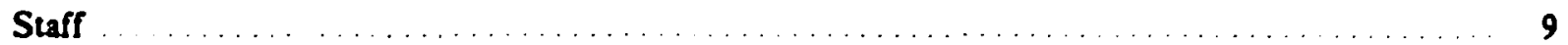

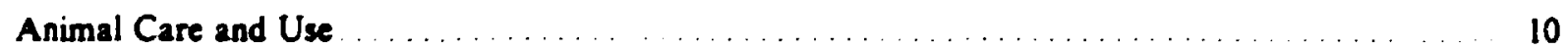

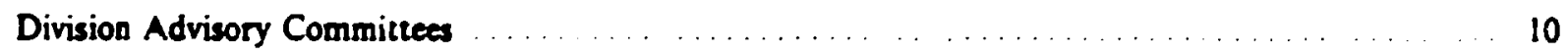

Human Studies . . . . . . . . . . . . . . . . . . . . . . . . . . . . 10

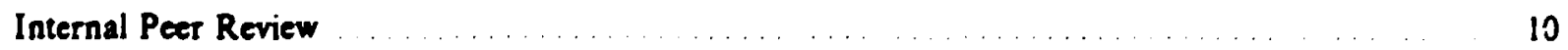

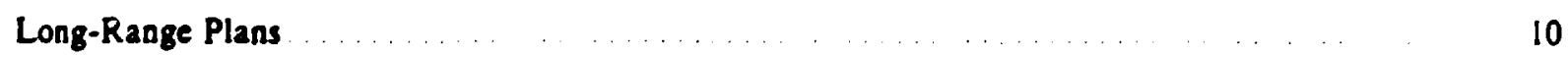

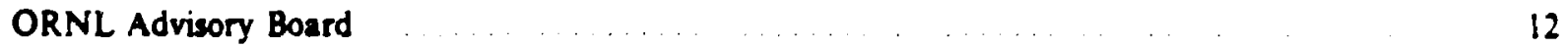

Performance Improvement Project . 12

Quality Assurance . . . . . . . . . . . . . . $\quad 12$

Orhers ... . . . . . . . . . 12

Research in Progreas. . . . . . . . . . . . . . . . . .

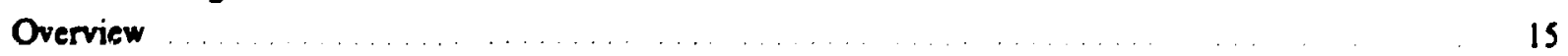

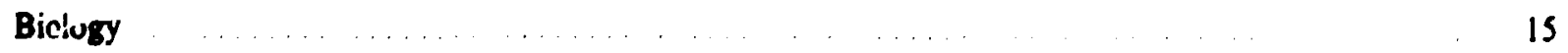

Environmental Sciences $\ldots \ldots \ldots \ldots$

Hedth an' Safety Research $\quad 19$

$\begin{array}{ll}\text { Program Accomplishments } & 23\end{array}$

Anaiytical Chemistry

Biology

Environmental Sciences $\quad 23$

Health and Safety Research $\quad 28$ 
Progran Orientation

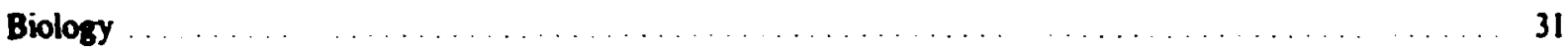

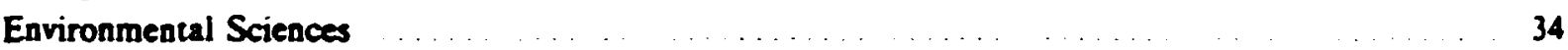

Health and Safety Research $\ldots \ldots \ldots \ldots \ldots \ldots \ldots \ldots \ldots$

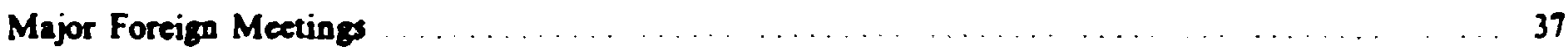

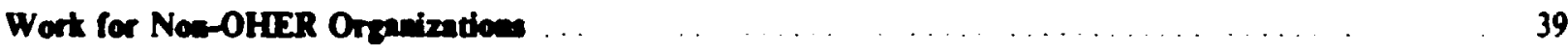

Other DOE Organizations . .

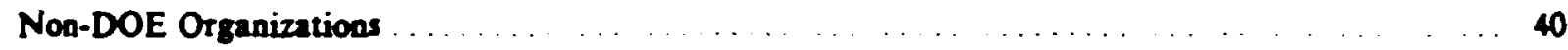

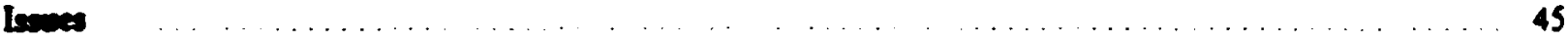

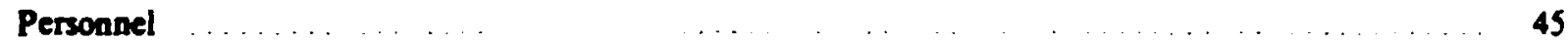

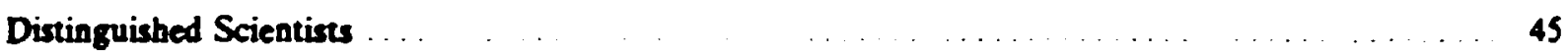

Capital Equipment . . . . . . . . . . . . 45

Work for Others .... . . $\quad \ldots \ldots \ldots \ldots$

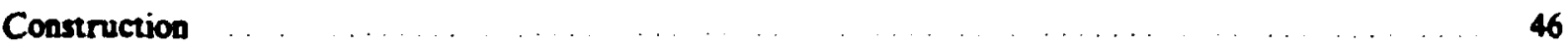

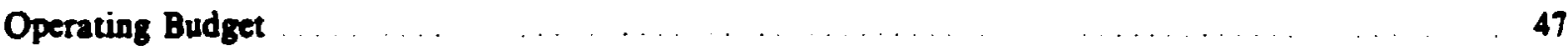

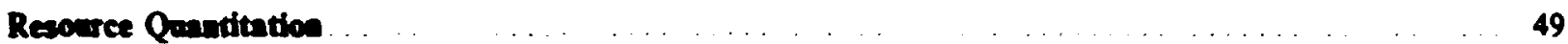

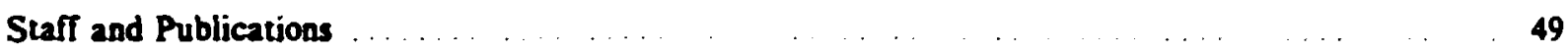

User Facility Statistics . . . .

Meetings Organized $\ldots \ldots \ldots \ldots \ldots \ldots \ldots \ldots$

References ... . . . . . . . . . . . 53

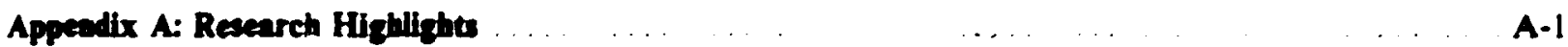

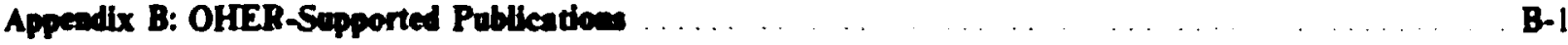




\section{List of Figures}

1 Sponsors of the Biomedical and Environmental Sciences Program at Oak Ridge National Laboratory

2 Organization chan for the Office of the Associate Director for Biomedical and Environmentai Sciences

3 Organization chan for the Biology Division

4 Organizztion chan for the Environmental Sciences Division.

5 Organization chan for the Health and Safety Research Division

6 The organizational performance planning and review process at Oak Ridge

National Laboratory, operated by Martin Marietta Energy Systems, Inc. 


\section{List of Tables}

1 Changes in Biomedical and Environmental Sciences Program professional personnel.

2 Members of Oak Ridge National Laboratory's Animal Care and Use Committee

3 Division Advisory Committee members for FY 1987 and FY 1988

4 Members of the Oak Ridge Associated Universities/Oak Ridge National

Laboratory Committee on Human Studies

5 Professional, corporate, and organizational awards received by Office of Health and Environmental Research-supported personnel in FY 1987

Professional, corporate, and organizational achievements received by Office of Health and Environmental Research-supported personnel in FY 1987

Editorial board memberships of Office of Health and Environmental

Research-supported personnel during FY 1987

8 Officers of societies among Office of Health and Envirunmental

Research-supported personnel during FY 1987

9 Oak Ridge National Laboratory/Office of Health and Environmental Research budget and subcontracts

10 Major foreign meetings during FY 1988 and FY 1989

11 Proposed line-item construction projects for Oak Ridge National Laboratory's Biomedical and Environmental Sciences Program

12 Oak Ridge National Laboratory Biomedical and Environmental

Sciences research staff

13 Office of Health and Environmental Research-supported publications 


\section{Acknowledgments}

We are grateful for the assistance received in preparing this document. The staff $f$ each division contributed to the written text and orcvided the needed statistics. Division coordinators were Beverly Selmer and Stan Cook, Biclogy, Judy Trimble, Environmental Sciences; and Jewell Ellis, Health and Safety Research. The locument was edited and coordirated by Jackie P, filler. Our thanks go also to V. B. Isham for all budget infor- mation; to Vickie Conner fo: the cover design; to Virginia Norman for obtaining the publications list in Appendix B; to Sandi Lyttle for composition; to Larty Davis for makeup; to Dottie MeMahan and G. A. Sweeden for graphics; to Lowell Langford, Paul Baker, and Bill West for advice and procedural assistance; and to the Photography Department for their assistance and advice. 


\section{Overview}

The role of the Biomedical and Environmental Sciences Program at Oak Ridge National Laboratory (ORNL) is closely liaked to the mission of ORNL and the Department of Energy (DOE).

\section{Mission of the ORNL Biomedical and Environmental Sciences Program}

A primary mission of the Biomedical and Environmental Sciences Program is to identify and understand important environmental and health effects associated with the energy technologies, including (1) basic and applied biological research on genetic and somatic effects of radiation and chemical exposures; (2) relationships of primary energy effluents to global environmental issues: (3) development of human health and environmental assessments and risk analyses in these areas; and (4) development of advanced instrumentation, measurement techniques, and methodologies for applying nuclear technologies to medical diagnosis and treatment. A secondary mission is to contribute to the revitalization of American industry through a variety of associations and activities, including cooperation with industrial corsortia, active promotion of user facilities, and an aggressive patenting and licensing program.

The Biomedical and Environmental Sciences Program is committed to the effective transfer of research and technological developments to the pri. vate sector, academia, and other research institutions, including, where possible, establishing joint research, education. and iraining programs with universities.

\section{Mission of Oak Ridge National Laboratory}

Oak Ridge National Laboratory is the Department of Energy's largest multiprogram energy laboratory. The Laboratory's primary missions are (1) to conduct applied research and engineering development in support of DOE's programs in fusion, fission, conservation, fossil, and otber energy technologies and (2) to perform basic scientific research in selected areas of the physical ard life sciences. A secondary mission is to apply the Laboratory's resources to other nationally important tasks when such work is synergistic with the primary mission. Some of the issues addresced under the secondary mission include technologies related to international competitiveness, hazardous waste research and development (R\&D), and selected defense technologies other than nuclear weapons. All missions include technology transfer as an integral component. In addition to the R\&D missions, ORNL performs very imporiant service roles for DOE: these roles include designing, building, and operating facilities for the benefit of university and industrial researchers and supplying radioactive and stable isotopes that are not available from private industry.

Scientific and technical effors in support of the Laboratory's miessions cover a spectrum of activities. In fusion, the emphasis is on stellarator confinement configurations, plasma heating, fueling systems, superconducting magnets, first-wall and blanket materials, and applied plasma physics. The ORNL nuclear fission activities suppor DOE's civilian nuclear power program through $R \& D$ on nuclear fuel reprocessing, high-temperature gascooled reactors. instrumentation and controls, 
nuclear and chemical wastes, and materials. The Laboratory's program on conservation and renew. able energy emphasizes research on hightemperature materials, electric power distribution systems, conservation technologies for buildings and industry, biomess production, and energy sturage. ORNL's fossil energy work concentrates primarily on materials and on innovative research in coal conversion and utilization. Basic and applied research in the physical, social, informational, and life sciences provides the foundation for the technology development work Biological and environmental research emphasizes the interaction of energy-related physical and chemical agents with the environment and with living organisms. Research in the social sciences includes policy analysis and technolosy implementation issues. The information area includes work on expert systems, simulations, and decision research. In the physical sciences, basic and applied research areas include high-temperature materials, neutron scattering, surface physies, aqueous and environmental chemistry, and heavy-ion physics. The role of providing research tools for industry and universities encompasees over a dozen major installations including the Health Physics Research Reactor (HPRR), the Oak Ridge National Environmental Research Park (NERP), the Oak Ridge Bioprocessing Research Facility (BRF), and other important user facilities related to energy technologies and the sciences.

\section{Missions of the DOE Multiprogram National Laboratories}

The main role of DOE's national laboratories is (1) to conduct basic research programs to advance the frontiers of scientific and technical knowledge in physical and energy-related life and environmental sciences that involve large multidieciplinary or major capizaj-intensive experimental facilities, and to provide use of those facilities to members of the scientific and technical community, including interested industry representatives or groups; (2) to conduct basic and applied researcb and technology development programs to explore energy technoio- gies and related envirunmental factors and develop research options in areas that involve large. unpredictable, and long-term risks, costs, or payofts, that need development before they can reach the market as competitive energy-investment options; (3) to conduct research, development, engineering. and technical and production support for auclear weapons, associated nuclear materials. and other defense-related activities; (4) to provide research and development support, as appropriate. to other government agencies and make special capabilities available for public and private sectors on a reimbursable basis; ( 5 ) to contribute, through cooperative programs with universities, to the education of scientists and engineers in the fundamental sciences and all energy-related technologies; and (6) to provide for and encourage the transfer of technology developed at the national laboratories to the private and public sectors and facilitate an interactive climate among the laboratories and industry.

\section{Goals of the Office of Health and Environmental Research}

Goals of DOE's Office of Health and Environmental Research (OHER) Program are (1) to study the interaction to energy-related physical and chemical agents with living organisms, including their transport, chemical evolution, adverse bealth effects, and ultimate consequences in humans and their environment: (2) to contribute to DOE's Nuclear Medicine Program and other beneficial applications programs; and (3) to transfer research findings and technological developments outside the Laboratory.

The ORNL HAO2 Program is one of the most multidisciplinary life sciences research programs in the nation and covers a broad range of both basic and applied studies. Overall, this program is expected to experience growth in global sciences, subsurface transport studies, and radon-related research in this planning cycle. 


\section{ORNL/OHER Facilities and Resources}

The administration and management of the Biomedical and Environmental Sciences Program are the responsibility of the Ascociate Laboratory Director for Biomedical and Environmental Sciences (ADBES), who reports directly to the ORNL Director. ORNL is a government-owned facility operated by Martin Marietta Energy Systerns, Inc., for DOE. The DOE OHER provides the largest funding source for ORNL's Biomedical and Environmental Sciences Program (Fig. 1). Biomedical and environmental sciences research is carried out primarily by three divisions: Biology. Environmental Sciences, and Health and Safety Research. Organizational structures are shown in Figs. 2-5. Changes in Biomedical and Environmental Sciences professional personnel for FY 1987 and anticipated changes for FY 1988 are summar- ized in Table 1 . A table showing current personnel totals, categorized by principal investigator, scientific support personnel, and others, is given in the Resource Quantitation section (Table 12). Other ORNL divisions that contribute to the ORNL BES multidisciplinary projects are Analytical

Takle 1. Cranges in Blanedical and Environeneatal Sciesces Progen profecuional persoend

\begin{tabular}{lcc}
\hline & FY 1987 & FY 1988 \\
\hline Arrivals & 20 & 10 \\
Departures & 27 & 15 \\
Status changes & -7 & -5 \\
\hline
\end{tabular}

Anticipated changes in personnel.

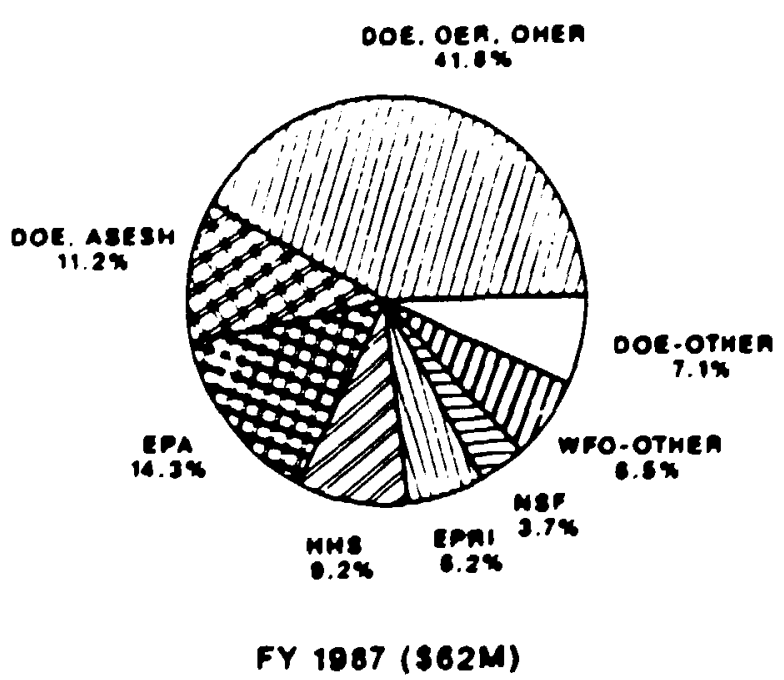

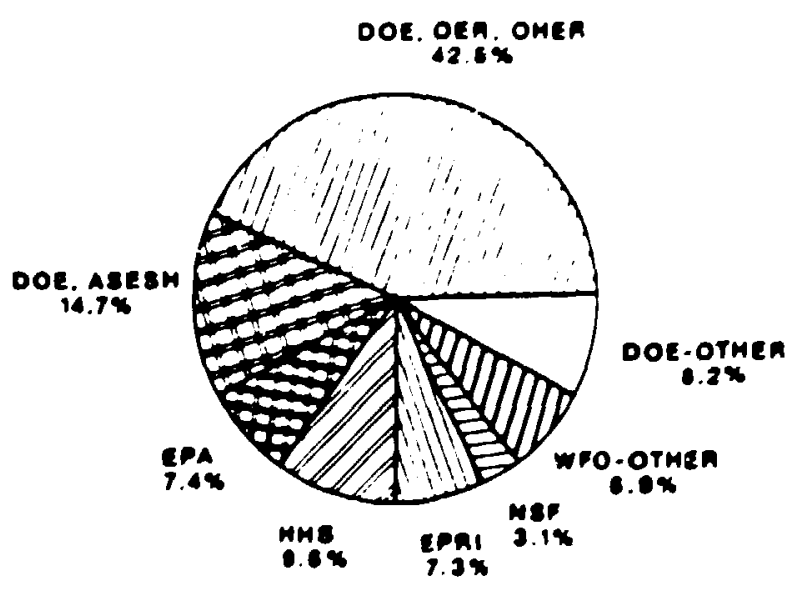

FY 1988 (S58M)

Fig. 1. Spowsors of the Blomedical and Eariroumeatal Sciences Program at Oak Ridge National Laboratory (total bodget is operating BO). 
BIOMEDICAL AND ENVIROMMENTAL SCIENCES

samuant icae

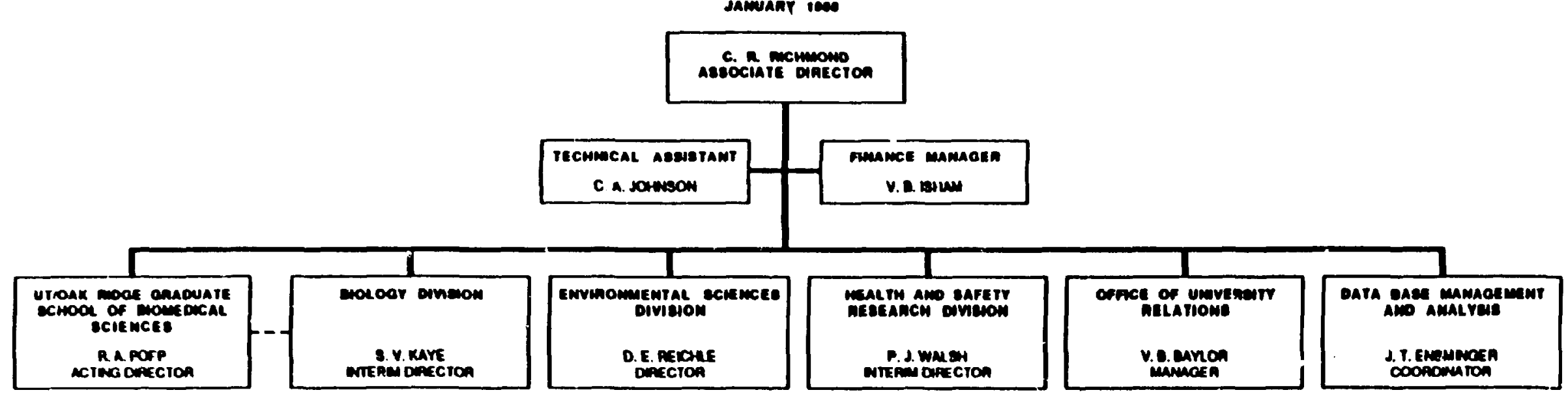

Fig. 2. Organization chart for the OMce of the Assoclate Director for Biomedical and Eavironmental Scleaces. 


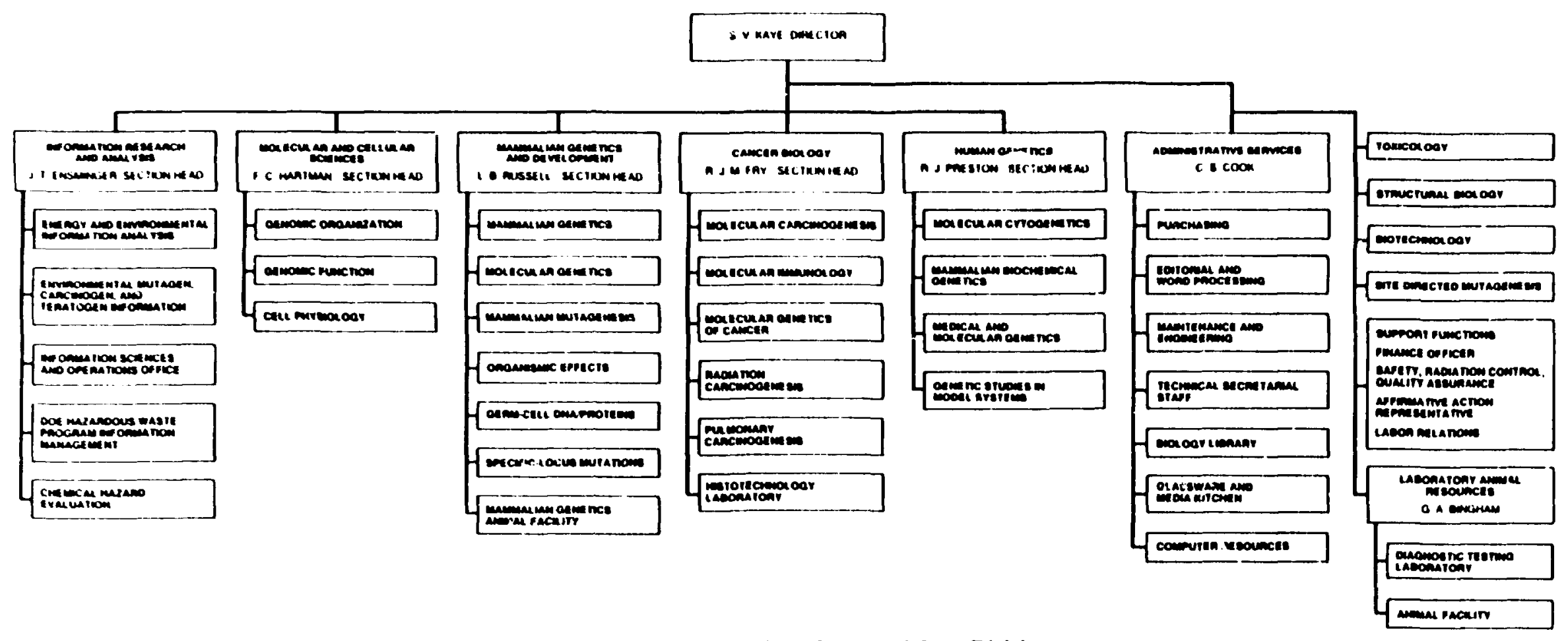

Fig. 3. Organization chart for the Blotogy Division. 


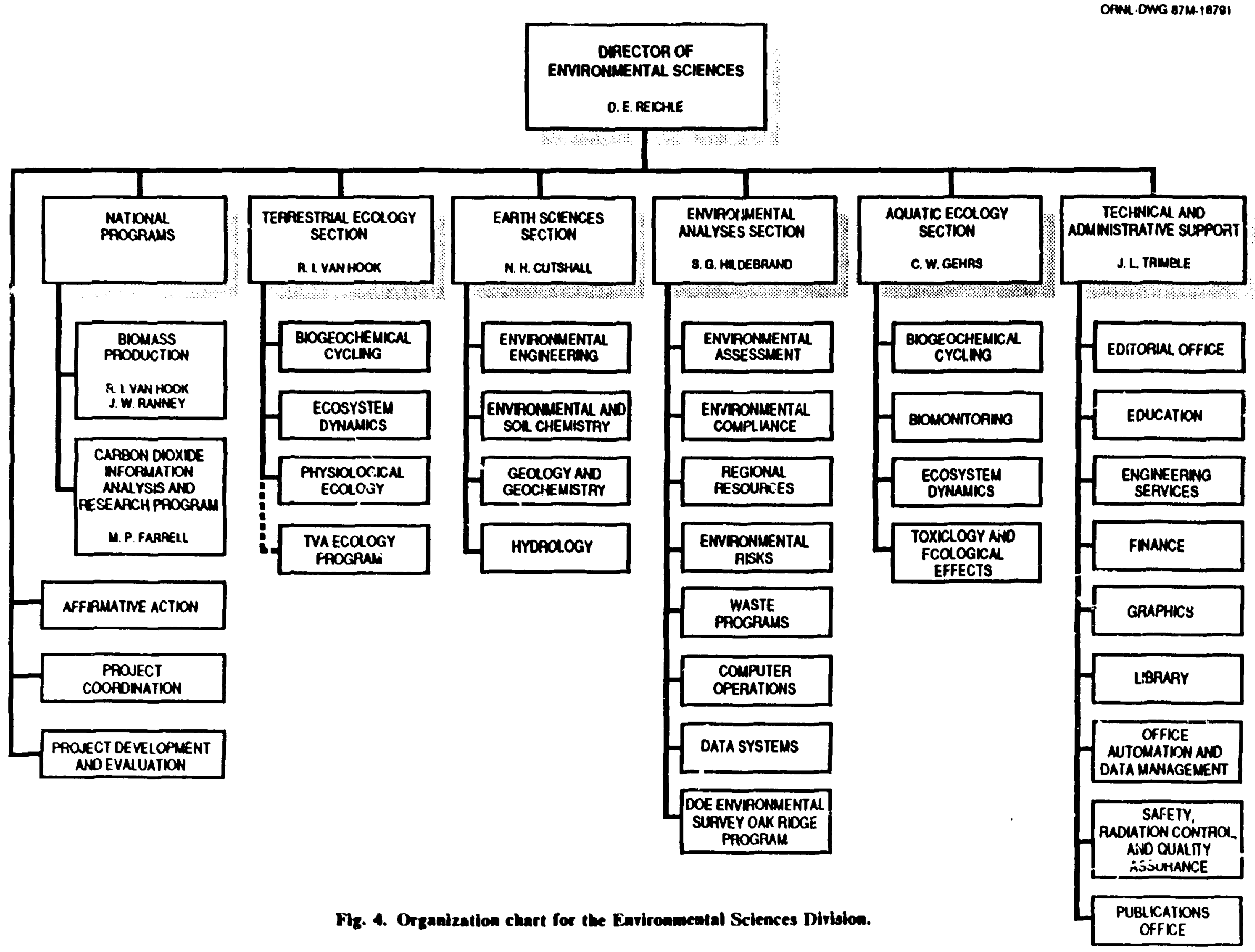




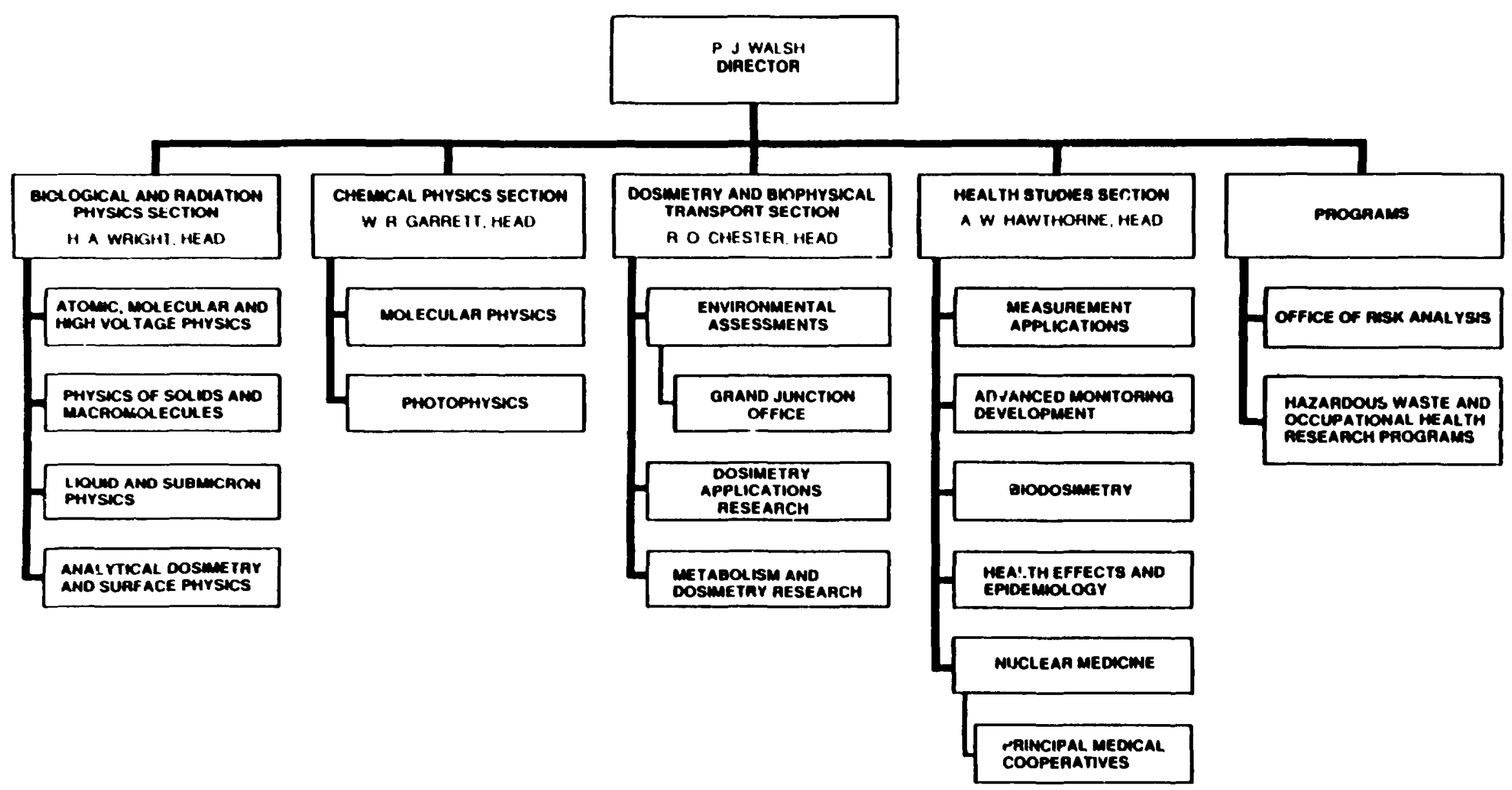

Fig. 5. Organization chart for the Health and Safety Research Division. 
Chemistry. Chemical Technology, Energy, Engineering Physics and Mathemntics, Instrumentation and Controls, Operations, and the Computing and i elecommunications Division of Energy Systems. In additic:, the ADBES is responsible for tive ORNL University Relations Program.

The University of Tennessee-Oak Ridge Graduste School for Biomedical Sciences is located in the Biology Division. The school offers a multidisciplinary program designed for 'raining toward the M.S. and Ph.D. degrees. Tae division provides four full-time faculty members as well as a major portion of the teaching and research training- In addition. The University of Tennessee (UT) in conjunction with the Biology Division offers an M.S. degree program in biotechnolosy. The first students entered this unique program in 1986. The Environmental Sciences Division also collaborates with UT to provide grajuate education and training in coology.

Three unique user facilities are supported by the DOE OHER: the Health Physics Research Reactor (HPRR), the 5500-ba (13,585-acre) Oak Ridge Nationai Environmental Research Park (NERP). and the Bioprocessing Research Facility User Resource. The NERP Program coordinates all environmental research activities with other land uses and serves as the repository of data on longterm rservation research. The bioprocessing facility incegrates physical resources from the Biology sod Chemical Technclogy divisions to include bioreactors, a flow cytometry latoratory, largevolume fermenters, and centrifugai analyziśs. Users of these facilities include staff of national laboratories and industry and students and staft from universities. 


\section{Research Management Practices}

Research projects under the auspices of the ADBES continually undergo review procedures to ensure quality, productivity, and effiviency. To belp accomplish the desired results, appropriate management measures are applied at various levels of the organization.

\section{Staff}

Formal yearly reviews are conducted for each staff member according to the Performance Planning and Review (PPR) System. Figure 6 illustrates the organizational performance planning process and the progression from the company's strategic plan to performance plans for individual salaried employees. The reviews are augmented by informal reviews that occur several times during the year. The PPR System has recently undergone comprehensive review and revision using input from outside consultants and ORNL staff. Career development reviews take place at years two and Tive.

ORNL-DWG 88-7107

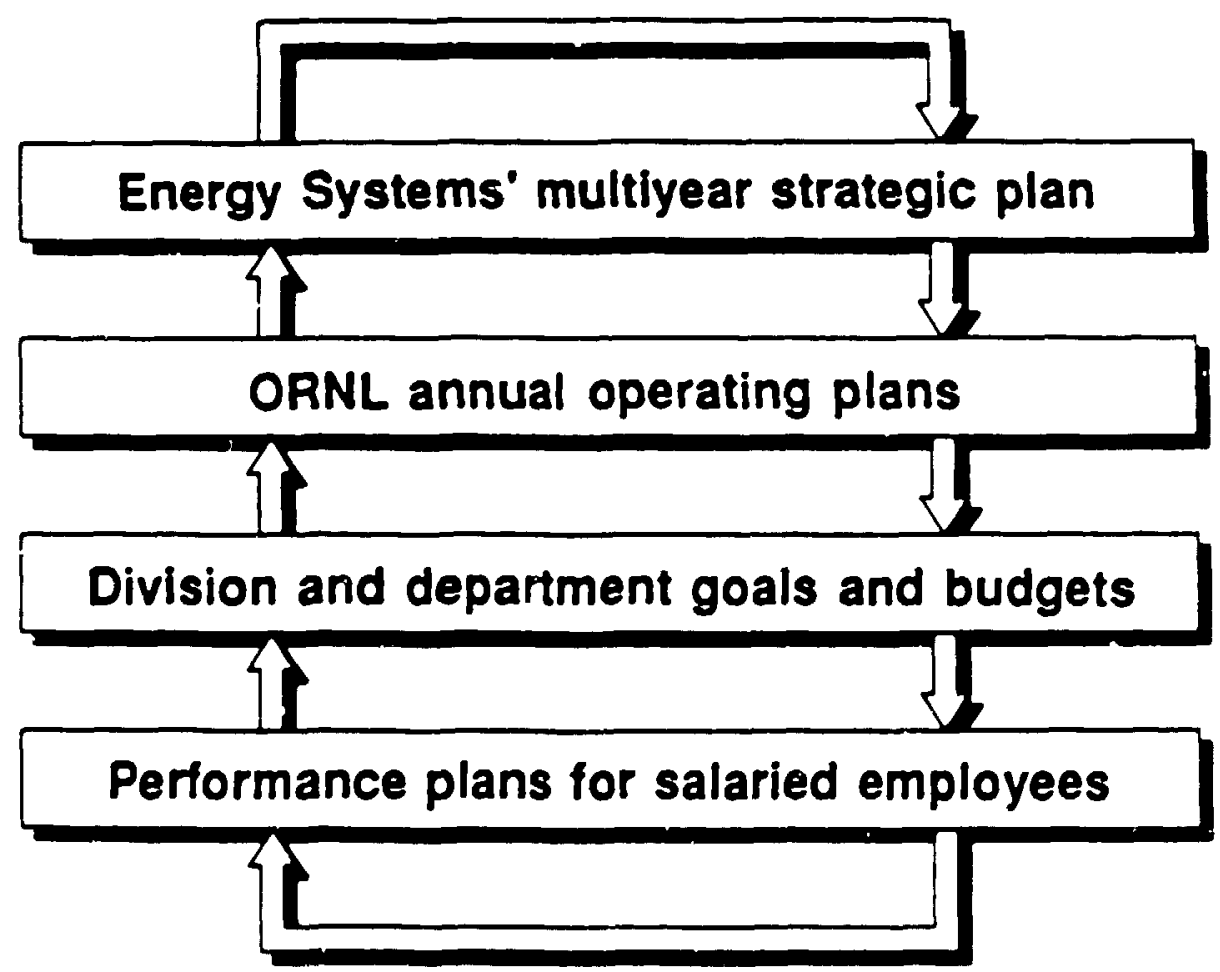

Fig. 6. The organizatioanl performance planning and review process at Oak Ridge National Laboratory, operated by Martin Marietta Eaergy Systema, Inc. 
A career review program identifies high-potential employees and, in concert with an aggressive affirmative action program, provides equal opportunities for minorities and women. Employee developmeat plans are prepared for these individuals. The plans are monitored by division directors, associate directors, and the Laboratory Director. Periodic reviews of some are conducted by the Professional Managers Improvement Committee.

\section{Animal Care and Use}

The care of laboratory animals at ORNL meets or exceeds the requirements of the U.S. Department of Agriculture, the policies of the National Institutes of Health and DOE, and the principles of humane care of the American Veterinary Medical Association. The facilities are accredited by the American Association for Accreditation of Laboratory Animal Care and are supervised by a laboratory animal veterinarian. The membership of the ORNL Animal Care and Use Committee is shown in Table 2.

\section{Division Advisory Committees}

Each division undergoes a regularly scheduled review by an outside advisory committee that constructively critiques research activities, long-range and strategic plannirg, and future directions. The committees present their recommendations directly to the Laboratory Director. The membership of the advisory committse for each division is shown in Table 3.

\section{Human Studies}

Reserrch involving buman su,jects at ORNL meets the requiremeats of the Department of Health and Huranen Services and DOE policy and the proposed policy of the Office of Science and Technology Policy on the protection of human subjects. For all research activities involving human subjects, the research proposals, consent forms, research practices, and research progrear are reviewed and approved by a Committee on Human Studies that serves both ORNL and the Oak Ridge Associsted Universities. The current members are listed in Table 4.

\section{Internal Peer Review}

All scientific publications and technical reports receive an internal peer review. This process series as a quality control check and is closely monitored by ORNL management.

\section{Long-Range Plans}

ORNL participates in the DOE multiprogram laboratories institutional planning cycle. Components of the planning cycle include submission of preliminary data, completion of the on-site review, and approval of the Institutional Plan. The plan includes the five-year bascline of program projec. tions and the fifteen-year strategic view for ORNL. The plan is an integration of DOE guid. ance and laboratory planning for $R \& D$.

Five-year R \& D plans are prepared by each division on a regular schedule to coincide with

Table 2 Menbers of Oat Ridee Nadbad Leboratory's (ORNL's) Anteal Care and Use Comaittee

\begin{tabular}{ll}
\hline \multicolumn{1}{c}{ Name and degree } & \multicolumn{1}{c}{ Amliation } \\
\hline Gene A. Biagham. D.V.M. & Chairperson, Biology Division. ORNL \\
Lorrie G. Beevers-Laurence, Ph.D. & Oak Ridge Psychocherapy Practice \\
R. J. Michael Fry, M.D. & Biolory Division. ORNL \\
John F. MeCariay, Ph.D. & Environmental Sciences Division. ORNL \\
Edward C. Schroeder, D.V.M. & College of Veterinary Medicine, \\
& The University of Tennessee, Knoxville \\
\hline
\end{tabular}


Table 3. Division Advisory Connitte nembers for FY 1987 an FY 1988

\begin{tabular}{|c|c|c|}
\hline $\begin{array}{l}\text { Committec } \\
\text { member }\end{array}$ & $\begin{array}{l}\text { Year } \\
(F Y)\end{array}$ & Afruliation \\
\hline \multicolumn{3}{|c|}{ Biology Division } \\
\hline Dr. Rebert Barker & 1987 & $\begin{array}{l}\text { Provosh, Cornell University } \\
\text { 3U9 Day Hall } \\
\text { Ithea, New York } 14853\end{array}$ \\
\hline Dr. Verne M. Chapman & 1987 & $\begin{array}{l}\text { Chaiman, Department of Molecular Biology } \\
\text { and Asecciate Director for Scieatific } \\
\text { Affairs } \\
\text { Roswell Part Memorial Institute } \\
\text { Buffalo. New York } 14263\end{array}$ \\
\hline Dr. Robert L. Dixon & $1987-88$ & $\begin{array}{l}\text { Director of Toxicology } \\
\text { Sterling-Winthrop Research Institute } \\
\text { Columbia Turnpike } \\
\text { Renselser, New York } 12144\end{array}$ \\
\hline Dr. Lorraine Flaherty & $1987-88$ & $\begin{array}{l}\text { Chief, Laboratory of Immunology } \\
\text { Wadsworth Center for Laboratories and } \\
\text { Research } \\
\text { New York State Department of Health } \\
\text { Albany, New York } 12201\end{array}$ \\
\hline Dr. Henry C. Pitot & 1987 & $\begin{array}{l}\text { Ditector, McArdle Laboratory for Cancer } \\
\text { Research } \\
\text { The University of Wisconsin } \\
\text { Madison, Wisconsin } 53706\end{array}$ \\
\hline Dr. William J. Schull & 1988 & $\begin{array}{l}\text { Director, Center for Demographic } \\
\text { Population Genetics } \\
\text { The University of Texas Health } \\
\text { Science Center } \\
\text { Post Office Box } 20334 \\
\text { Houston, Texas } 77225\end{array}$ \\
\hline Dr. Shirley M. Tilghman & 1988 & $\begin{array}{l}\text { Howard A. Prior Professor } \\
\text { of the Life Sciences } \\
\text { Department of Molecular Genetics } \\
\text { Princeton University } \\
\text { Princeton. New Jersey } 08544\end{array}$ \\
\hline \multicolumn{3}{|c|}{ Environmental Sciences Division } \\
\hline Dr. Charles R. Goldman & 1987 & $\begin{array}{l}\text { Professor of Limnolosy } \\
\text { Director of Tahoe Research Group } \\
\text { Division of Environmental Studies } \\
\text { University of California } \\
\text { Davis. California } 95616\end{array}$ \\
\hline Dr. Charles J. Mankin & $1987-88$ & $\begin{array}{l}\text { Director, Oklahoma Geological Survey } \\
\text { The University of Oklahoma } \\
\text { Norman. OkJahoma } 73019\end{array}$ \\
\hline Dr. Leonard $H$. Weinstein & 1987 & $\begin{array}{l}\text { Program Director, Envitonmental Biology } \\
\text { Boyce Thompson Institute for Plant } \\
\text { Research } \\
\text { Cornell University } \\
\text { Ithaca, New York } 14853\end{array}$ \\
\hline
\end{tabular}


12 Bionediee! and Envirosmental Scieaco Program at ORNL

Talle 3 (centinan)

\begin{tabular}{|c|c|c|}
\hline $\begin{array}{l}\text { Committee } \\
\text { member }\end{array}$ & $\begin{array}{l}\text { Year } \\
\text { (FY) }\end{array}$ & Affiliation \\
\hline Profeceor M. Gordon Wolr an & $1987-88$ & $\begin{array}{l}\text { The Johns Hoptins University } \\
\text { Departmeat of Geography and Environmental } \\
\text { Engineering } \\
\text { Beltimore, Maryland } 21218\end{array}$ \\
\hline \multicolumn{3}{|c|}{ Health and Safery Research Division } \\
\hline Dt. I. Norman Bardsley & $1987-88$ & $\begin{array}{l}\text { Lawrence Livermore National Laboratory } \\
\text { P.O. Box 808, MS L-296 } \\
\text { Livermore, California } 94550\end{array}$ \\
\hline Dr. A. Welford Castleman & $1987-88$ & $\begin{array}{l}\text { Penarylvania State University } \\
\text { Colleze of Science } \\
\text { is2 Davey Laboratory } \\
\text { University Park, Peansylvania } 16802\end{array}$ \\
\hline Dr. William \&. Mills & $1987-88$ & $\begin{array}{l}\text { Senior Technical Advisor } \\
\text { ORAU/CIRRPC } \\
\text { 1019 19th Street NW E700 } \\
\text { Washingtoa, D.C. } 20036\end{array}$ \\
\hline Dr. John M. Palms & $15,67-88$ & $\begin{array}{l}\text { Vice-Presiden: for Academic Aflairs } \\
\text { and Profewor of Physics } \\
\text { Emory University } \\
\text { Atlante, Georgia } 30322\end{array}$ \\
\hline
\end{tabular}

Advisory Committce reviews. The division plans address research directions and goals. In addition, the plans identify future resource needs and a strategy for achieving the stated goals. The

Laboratory's senior management reviews and approves division plans.

\section{ORNL Advisory Board}

The charter of the ORNL Advisory Bcard is to critique and provide advice on ORNL's goals and missions and to give general guidance to future directions. Convened for the first time in June 1984, the board meets semiannually. Dr. W. J. Rutter of the University of Califernia is the member of the board who closely reviews the ORNL BES Program.

\section{Performance Improvement Project}

During FY 1985, the Performance Improvement Project (PIP) was initiated by Martin Marietta Energy Systems, Inc. PIP is designed to measure improvement, activities, or projects; identify and implement opportunities for improvement; and enhance recognition and awards programs. Formal training in the PIP concept is provided to all monthly employees to ensure awareness of and total participation in PIP.

\section{Quality Assurance}

Quality assurance (QA) is a high priority at the Laboratory; it is accomplished through close working relationships between divisional QA coordinators and ORNL QA. staff.

\section{Others}

Othe: management tools, such as planning retreats, conmitment systems, and subcontract and financial tracking systems, belp to ensure sound management of BES programs. Such widely used tools as the electronic mail system and computerized tracking systems help expedite communication for managers as well as staff.

A comprehensive human research development program provides opportunities to salaried employees for further training in their fields and for broaden. 
Table 4. Menbers of the Oak Ridee Anaciated Universities/Oak Ridge National Laboratory Compittee on Henen Stadies

\begin{tabular}{|c|c|}
\hline Name and degree & Afriliation \\
\hline William W. Burr, M.D. & Oak Ridge Associated Universities \\
\hline William H. Calboun. Ph.D. & The University of Tennessee \\
\hline James E. Crook, M.D. & Oak Ridge Aseocinted Universities \\
\hline Kenseth Flatt, B.S. & Onk Ridge Associated Universities \\
\hline Howard R. Friedman. Ph.D. & Regional Mental Healib Centet \\
\hline R. J. Mishael Fry, M.D. & Ont Ridge National Laboratorv \\
\hline Shirley Fry, M.B., B.Ch. (MPH) & Oak Ridge Associated Universities \\
\hline A. Seaton Garrett, Jr., M.D. & Oak Ridge National Laboratory \\
\hline Stephen V. Kaye, Ph.D. & Oak Ridge National Laboratory \\
\hline Karl F. Huboes, M.D. & The University of Tennessee \\
\hline Melvin E Koons, J.D. & Tennescee Innovation Center \\
\hline Robert Lange. M.D. & The Uaiversity of Teanessee \\
\hline Ten-Ching Lee, Ph.D. & Oak Ridge Aseaciated Uaiversities \\
\hline C. C. Lushbaugh, M.D. & Oak Ridge Ascociated Universities \\
\hline L. Clifford McKe, M.D. & Vanderbilt University \\
\hline Ruby L. Miller, B.S. & Martin Marietu Energy Systems, Inc. \\
\hline
\end{tabular}

ing their education. Selected managers and staff with high potential are given the opportunity to attend management-training seminars conducted by outside organizations, including universities. 


\section{Research in Progress}

\section{Overview}

The major goals of ORNL's Biomedical and Environmental Sciences Program are (1) to study the interaction of energy-related physical and chemical agents with living organisms, including their transport, chemical evolution, adverse health effects, and ultimate consequences in bumans and in their environment: (2) to contribute to DOE's Nuclear Medicine Program and other beneficial applications programs; (3) to transfer research findings and technological developments outside the Laboratory; and (4) to collaborate, where possible, with universities and the private sector.

Research areas in biology include mammalian genetics, molecular genetics, protein engineering. carcinogenesis, radiation biology, and chernical interactions and effects. Environmental science research covers biogeochemistry, hydrology, environmental toxicology, global ecology, envitonmental risk analysis, geology, carbon dioxide $\left(\mathrm{CO}_{2}\right)$, and acidic deposition. Health and safety research encompasses epidemiology, health assessments, radiation and chemical physics, dosimetry, nuclear medicine, and instrumentation development for sensitive detection and monitoring of chemicals.

In addition, three unique user facilities are supported by OHER: the HPRR, the NERP, and the Bioprocessing Research Facility User Resource. The NERP program coordinates all environmental research activities with other land uses and serves as the repository of data on long-term reservation research. The bioprocessing facility integrates physical resuurces from the Biology and Chemical Technology divisions to include bioreactors, a now cyometry laboratory, large-volume fermenters, and centrifugal analyzers. Users of these facilities include staff of national laboratories and industry and students and staff from universities. We are in the process of integrating the laboratory's structural biology research activities. These activities are mainly distributed among five ORNL divisions.

\section{Biology}

The Biology Division's research centers on the mechanisms of action of deleterious agents on binlogical systems, particularly genomic effects of energy-related substances. The approach to this work is experimental and uses materials at all lev. els of biological organization to obtain data for predicting and understanding potential hazards to human health. The major areas of emphasis are heritable genetic effects, mutagenesis, and carcino genesis, all of which involve molecular, cellular. and organismal studies of the consequences of damage to genetic materials. The division has major responsibilities and unique capabilities for genetic studies in mice, protein engineering, and radiation carcinogenesis.

\section{Mammalian Genetics}

The continuing program in mouse genetics and germ-line mutagenesis has been vitalized by the strong emergence of new themes made possibie by staff additions and collaborative efforts with other laboratories. To undserstand the mechanisms for. and assess the risk from, the induction of heritable mutational damage, the program seeks to perfect methods for efficient detection of such damage. explore factors that affect yield, investigate the organismic expressions of mutations, and analyze the structural nature of the damage at the chromosome, gene, and molecular levels. Other closely related developing themes concern the area of 
molecular analysis of structure and function of several specific regions of the mouse genome. The altered genes and chmmosomes that have been (and continue to be) produced in the course of mutagenesis experiments (and are subsequently maintaised as mouse stocks) supply an unparalleled wealth of genetic tools for these molecular analyses. Reciprocally, as knowledge of the molecular structure of a region is obtained, elucidation of the manner of action of mutagenic agents is facilitated In addition, studies are being performed on the mechanism of induction of chromosomal alterations and gene mutations and their role in adverse genetic and somatic effects. The adveat of molecular techniques has made such studies considerably more informative. Ose approach to relating molecular structure of genomic regions to gene action is by insertional mutagenesis via transgenic mouse technology (injection of DNA into a zygote nucleus). To strengthen the emerging themes in mammalian genome analysis, two moleculat geneticists have been added to the staff.

\section{Molecular Genetics}

Areas of emphasis in molecular genetics include genomic structure, regulation of gene expreasion, and structure and function of gene products. Visualization of higher-order chromatin structure and the three-dimensional structure of nuclecemes (the core particle of chromatin) utilize special ischniques in electron microscope tomography developed locally and $X$-ray diffractometry. Cloning of segments of the eukaryotic genome and their subsequent sequencing will provide insights about the nature of regulatory elements of DNA and the propensity of small regions of DNA to undergo spontaneous mutations. Model systems being used to study the regulation of gene expreasion include oncogenes (associated with the conversion of normal cells to cancer cells), mammalian genes that are under hormonal control, and mouse globin genes that provide an experimental system for thalassemia, a buman genetic disorder. Gene products under close scrutiny include ribulosebisphor phate carboxylase (a determinant of biomass yield), epidermal grownh factor (a polypeptide intimately involved in cellular grown and differentia. tion), enzymes involved in transcription of DNA. enzymes involved in the repair of chemically damaged DNA. and membrane transport proteins that are responsive to eavironmental insults.

\section{Protetio Engimearias}

Protein engineering (site-directed mutagenesis), an emerging program that is unique among DOE laboratories, integrates many activities in molecular genetics. The ability to program specific mutations into cloned genes will permit the systematic design of new gene products as mechanistic probes of protein function and the tailoring of operons to alter the regulation of gene expression. Molecular modeling with three-dimensional computer graphics will guide the selection of mutant gene products to be constructed and will serve as a predictive tool of the probable structural consequences. Because protein engineering provides an avenue for optimizing functional properties of enzymes, it umpinges on bioprocessing.

\section{Radiation Carcinogenesis}

The rescarch program in radiation carcinogenesis includes two major components, experiments designed to improve the assessment of health risks from exposure to radiation and related, fundamental studies of the genetic and host factors that are responsible for the progression of cancer. The objectives of the research are to provide data required for estimates of cancer induction by high linear-energy transfer (LET) radiation and lowLET radiation, to investigate the factors that influence expression and suppression of radiation. induced initiation of potential cancer cells, elucidation of the nature of the factors that control expression of potential cancer cells, development of methods to extrapolate risk estimates for radiation cancer induction. and to attempt to distinguish cancers on the basis of the causative agent. Two collaborative studies are in progress, one with Lawrence Berkeley Laboratory on heavy ion carcinogenesis and one with the Inhalation Toxicology Research Institute on the role of pyrimidine dimer repair in ultraviolet (UV) radiation-induced damage. Planned in addition are radon and related high-LET studies on (I) alpha-paricle activation of orcogenes, (2) gene rearrangement involving mobile gene elements, (3) induction of chromosome aberrations, (4) malignant transformation of tracheal cells, and $(\zeta)$ determination of radiation biological effectiveness for alpha-particle-induced 
cancers. A search is currently in progress for an additional molecular biologist to contribute to these studies.

\section{Health Effects Information Research}

The information research program provides an active interface between bench scientists and the rapidly expanding base of information. Sound scientific data management, analysis, and validation provide the basis for accurate research decisions as well as reliable health hazard evaluations and risk assessments. The development and application of such data resources is a top priority and is carried out in a variety of research areas. More than 80 data bases are being maintained. The concept is epitomized by the ongoing Genetic Toxicology Program and the Hazardous Substances Data Bank. The Environmental Mutagen Data Base alone contains 61,000 rezords on 18,000 chemicals. Quality assurance is a major driving force in these as weil as other data resource development projects. Quality control procedures are implemented during data base development and followed by intensive review by panels of experts to help ensure the accuracy and completeness of the file contents. Detailed knowledge of such data resources makes possible their application to several areas of concern related to the potential health and envir. inmental effects of hazardous materials. Many hazard assessment working documents and publications continue to be developed fo: DOE and other government agencies. On a local basis, the capabilities and resources have been used to develop a computerized Materials Safety Data Sheet system for informing Energy Systems employees of potential hazards on the job and to assist in the study and cleanup of the environment around the Oak Ridge facilities. Along with these activities, the evaluation of evolving computing technologies and their application in customized computing systems is a continuing and growing area of involvement.

\section{Environmental Sciences}

Environmental research is designed to increase the ability to predict transport and effects of energy. related contaminants in the environment. Basic information is developed on mechanisms that govern ecosystem function, particularly in biogeo- chemical cycling studies on eastern watersheds. Through utilization of process studies with stable elements, radionuclides, and trace organics as well as mathematical simulation models, data and methodologies are developed that enhance abilities to site and operate energy systems in a costeffective and environmentally safe manner.

\section{Integrated Watershed Research}

Over the past 20 years, Walker Branch watershed (WBW) on the DOE Oak Ridge Reservation (ORR) has been the site of extensive research that has resulted in the development of new concepts and techniques in watershed science. This work has brought national and international recognition in the area of biogeochemical cycling to ORNL and DOE. As investigations on WBW bave entered their third decade, it is timely to review and refine the research objectives. The focus of the WBW Integrated Research Program for the next decade will be on the hypothesis that hydrologic, aeolian (i.e., wir. 1), and biogeochemical linkages between upslope and downslope subsystem control the structure and productivity of watersheds. This research program involves a unique mix of scientific approaches and tools, including the integration of field characterization studies, laboratory and field experiments, and systems analysis and modeling; networks of state-of-the-art physical and chemical sensors and computer data-acquisition systems; extensive use of tracers to quantify pathways and rate processes; and experimental manipulations of watersheds.

\section{Traisport and Transformation}

Understanding and predicting the effects of air pollution on forests must be based on accurate measures of the flux of airborne materials to the landscape. Existing methods of measurement are limited by chemistry and time constraints, and alternative approaches are required. Detailed studjes of the interactions of precipitation with the forest canopy and the resulting chemistry of rain below the canopy are being used to develop methods to determine long-term mean fluxes of dry-deposited particles under field conditions. These methods and our results have been widely applied in other research by state, university, private, federal, and international agencies interested in the acidic rain phenomenon. 


\section{Coastal Trassport and Accmanatation Procesces}

This research involves the measurement of aaturally occurring and man-made radionuclides to trace and quantify transport and accumulation processes within the cosstal zone. The high correlation between the transport and deposition of radionuclides and many other trace substances-such as hazardous organics, trace metals, and pesticides-makes it possible to infer the distribution and biogeochemical fate of a large number of substances from relatively simple and inexpensive analyses of radionuclides. Recently, in cooperation with scientists from Skidaway Institute of Oceanography, these sensitive techniques have been used to show that constal bays and estuaries serve as effective traps for substances transported landward from oceanic sources as well as for materials transported downstream from drainage basin sources. In addition, these techniques are now being applied in contaminant transport and fate studies being conducted in freshwater systems in the Southeast. For example, radionuclides released from Oak Ridge Facilities are being used to elucidate short- and long-term processes controlling contaminant transport and biogeochemical fate in stream, river, and reservoir ecosystems. Technical zuidance on environmental research is provided to DOE programs and offices on a regular basis.

\section{Sobsurface Transport Procesess}

Research in the subsurface sciences is directed toward defining, understanding, and predicting the movement of energy-related contaminants in the subsurface in humid regions with highly organic natural waters. Association with natural organic colloids may alter the transport and fate of contaminants. The program consists of field and laboratory studies that are integrated with development and application of hydrologic and chemical trans. port models. New areas of emphasis include research on the role of colloids and microbial populations in affecting subsurface transport and transformation of energy by-products. ORNL will continue to support OHER's Site-Directed Subsurface Initiative. Unique field facilitios consist of fully instrumented watersieds in which chemicals can be released and traced as they move through the soils in one, two, or three dimensions. Field. derived data are used in model development and verification.

\section{Biological Responses to Stress}

The productivity and biogeochemistry of forest ecosystems is highly dependent on the growth and physiology of component forest tree species, and OHER-sponsored research is addressing the processes governing the response of terrestrial vegetation to environmental stresses of natural and anthropogenic origin. Using a combination of field and laboratory studies, research is focusing on the mechanisms controlling (1) exchange (deposition and emission) of trace gases of the atmospherebiosphere interface, (2) photosynthetic carbon dioxide assimilation and water use efficiency, and (3) interactive effects of multiple stresses on terrestrial vegetation. Each of these tasks is being addressed from the perspective of whole-plant physiology.

\section{National Enviromental Research Park}

In 1980, 5500 ba (13,585 actes) of the ORR were designated as a NERP. Although not primarily a research program, the Oak Ridge NERP provides protected land areas with a data base of information and in close proximity to Laboratory facilities for research. The park lies in the heart of an eastern deciduous forest area of streams and watersheds, mesic hardwood forests, and extensive upland mixed forests. Elaborate monitoring systems enable users to measure environmental factors precisely and accurately for extended periods. Various sites in the park offer opportunities for aquatic, atmospheric, and terrestrial ecosystem analyses, such as biogeochemical cycling of pollutants resulting from energy-producing facilities, landscape alterations, and forest and wildlife management.

Use of the NERP by ORNL staff, university, high school, and junior bigh school personnel and other agencies has increased over the last five years and is expected to continue to increase. Current research programs is the park include a study of the effects of atmospheric deposition on vegetation. short-rotation woody crops field trials, and studies on how physiological processes in plants and forest nutrient relationships are influenced by intensive silviculture and biological monitoring of ORR streams and reservoirs.

\section{Carbon Dioxide Research and Amalysis Propram}

This activity is managed by ORNL for DOE and has been realigned along with other components of 
the DOE Cazbon Dioxide Research Program for the next five-year effort. New research is acticipated in resource analysis. Integrated regional resource analysis models will be developed to account for the responses of resources to the increasing $\mathrm{CO}_{2}$ concentraiion and resulting climatic change. Research efforts focess on assembling and implementing disaggregatev (multidimensional) models of the global carbon cycle. Managemu... activities involve contract execution activities for the DOE Carbon Dioxide Research Program. particularly in the areas of oceanic and atmospheric data collection and analvsis. This broad array of activities and expertise is necessary for developing the information and models needed to provide accurate projections of $\mathrm{CO}_{2}$ buildup in the atmosphere over the next century from both natural and anthropogenic sources. Direct and indirect effects of $\mathrm{CO}_{2}$ on forest communities are being evaluated through both experimental and mathematical simulation exercises.

The Carbos Dioxide Information Analysis Center ( $\mathrm{CDIAC}$ ) supports the nation's $\mathrm{CO}_{2}$ research program and cooperates in information exchange with the international scientific community by addressing global atmospheric $\mathrm{CO}_{2}$ problems. CDIAC's research reflects new programmatic directions, with emphasis on novel approaches to the explor 2 tory analysis of highly variable data and to synthesizing information for evaluating complex environmental issues. CDIAC provides details on content, accessibility, format, and usefulness of the reeded data sets. In addition to literature and numeric data, CDIAC collects, organizes, evaluates, packages, and disseminates computing tect. nology (algorithms, codes, and models) as needed to support a global assessment of the $\mathrm{CO}_{2}$ issue.

\section{Landscape Patterns and Procesces}

For the past decade, ORNL has conducted a series of studies on the fundamental properties of natural systems and the response of these systems to natural and buman disturbances. The scale of these studies has ranged from microcosms beld under laboratory control to discrete watersheds in the southeastern United States. Our research indicates that detailed site-specific problems are not readily extrapolated to broader spatial scales, while broad-scale analyses have lacked the resolution necessary to incorporate detailed studies of spatial heterogeneity. Therefore, there has been a growing need to coalesce these widely disparate studies to develop first-order principles that address landscape problems.

We are currently conducting theoretical and modeling studies designed to develop methods for measuring ecological patterns of natural and managed landscapes, relating these patterns to processes, and extimating how these patterns will change as a result of broad-scale disturbances. Research results will be used to organize information from laboratory and site-specific studies for extrapolation to landscape scales. Extrapolation will provide several applications and may lead toward a general theory of landscape ecology with application to site management issues.

\section{Anticipatiog Global Change}

ORNL continues to offer the strongest encouragement and technical support to OHER planning for a global sciences initiative.

\section{Health and Safety Research}

Health and safety research is direeted toward basic and applied research involving the potential health impacts of energy-related technologies.

Research includes (1) studies of the properties of physical, biological/chemical, and environmental systems and their interactions, (2) developing measurement capabilities that meet present and future needs for assessing exposures of people to various insults, and (3) assessment methodologies that allow quantitative evaluations concerning the present and future impacts of various energy strategies, energy production levels, and potential energy-related mishaps.

\section{Radiation Calibration Leboratory}

The Health and Safety Research Division is responsible for RADCAL, a new facility to house radiation sources and equipment for (1) radiation dosimetry research, (2) testing of compliance with performance standards, (3) expanding existing dosimetry intercomparison studies, (4) :raining of dosimetrists, and (5) calibration of operational instruments.

This facility is currently being outfitted with beta. gamma, neutron, and $X$-ray radiation sources. All combinations of NBS-calibrated sources are being installed to meet the requirements of the two U.S. 
performance standards test programs: National Voluntary Laboratory Accreditation Program and the Department of Energy Laboratory Accreditation Program.

\section{Metabolism and Docinetry Research Stadies}

Research in metabolism and dosimetry is directed toward understanding the relationship between radiation exposure and the dose to organs of the body. These relationships are defined through the modeling of the metabolism of radionuclides taken into the body and the modeling of the deposition of ionizing energy within the radiosensitive tissues from these intakes or from exposures to radiation external to the body. Such relationships provide a cornerstone for development of radiation protection guidelines for the numerous radionuclides encountered in the workplace and environment and serve an important role in the evaluation of diagnostic procedures involving radiopharmaceuticals and diagnostic X-ray machines. Development of metabolic and dosimetric models that allow consideration of special characteristics of individuals or of segments of the population is now in progress.

\section{Dosimetry for Homan Expoures}

Critical contributions to the joint U.S.-Japan Dosimetry reevaluation effor were completed and are documented by the authorship of three chapters in U.S. -Japan Joint Reassessment of Atomic Bomb Radiation Dosimetry in Hiroshima and Nagasaki, Vol. I, W. C. Roesch, editor, Radiation Effects Research Foundation, Hiroshima, Japan (1987). The publication documents in detail a new nuclear radiation dosimetry system, DS86. resulting from a joint, seven-year U.S.-Japan dosimetry reassessment effort. The dosimetry system was developed after extensive reexamination of existing human exposure data and incorporation of recent information. The new dosimetry system will support more accurate, defensible estimates of risk from radiation exposure.

G. D. Kert spearheaded important parts of the U.S. technical effort and assisted in the completion of the cited publication "hile on assignment in FY 1987 to the Radiation Effects Research Foundation in Hiroshima.

\section{Chemical and Radiotopical Physics}

The physical and techriological research activities under OHER supporn are directed toward increas- ing knowledge of the interactions of potentially hazardous agents with biological and environmental systems and toward ensuring a technical capability for characterizing and quantitatively measuring such agents in various settings. The research consists of studies of the structures and properties of materials of biological or environmental importance; the physical and chemical mechanisms that govern the formation, transport, and cnemical transformation of radiation products in liquid media; the pollutants in the atmosphere, hydrosphere, and biosphere; and of the development of advanced instrumentation needed to satisfy the requirements of OHER.

Included in the scope of this work are theoretical and experimental studies of interactions at the atomic, molecular, and macroscopic levels in solids, liquids, and gases and on solid surfaces and solidliquid interfaces. Also, detailed Monte Carlo studies are made of the physical and chernical evolution of radiation-induced products in natural media and in biological materials.

\section{Instrumeat Derelopeneat}

Emphasis is placed on developing techniques that provide advanced instrumentation for characterizing and sensitively detecting a wide variety of radiological and chemical species. Included in this effort are unique applications of laser optical tech. niques, UV and soft X-ray spectroscopic techniques, electron-beam microlithography, scanning tunneling microscopy, surface-enhanced Raman spectroscopy, and advanced neutron dosimetry and microdosimetry, and a new program in picosecond spectrographic studies.

A continuing research activity is the development of new instruments and measurement techniques to support evaluation of the potential health and environmental impact of developing energy technologiex. This research includes advanced studies on monitoring chen.ical exposures of humans through instrumentation and biological indicator systems. Results of this research have led to cost-effective luminescence techniques for rapid screening of samples containing polynuclear aromatic compounds as well as porable instrumentation for on-site use at operating facilities. Recently, applications have been made to the detection of DNA adducts. Development of promising techniques for other biological indicators is in progress. 
The OHER-funded developmental research has resulted in support from other agencies and organizations for applied studies. Transferring this technology to the commercial sector is an important objective that has met with noteworthy success in the past four years.

\section{Health Physics Research Reactor}

The Health and Safety Research Division was responsible for the HPRR through the first quarter of FY 1988. The reactor is ? unique research facility. A small, unshielded, unmoderated fast reactor. the HPRR yields up to $1 \times 10^{17}$ fissions in the pulse mode and $10 \mathrm{~kW}$ in the steady state mode. The HPRR is used _. technology transfer and in radiobiology and dosimetry research. It is also used for criticality alarm testing, weapon simulation, education, training, and instrumentation development. Stewardship for this facility is being considered by another division.

\section{Nuclear Medicine}

The Nuclear Medicine Program is involved in the design, development, and animal testing of new radiopharmaceuticals for diagnostic and therapeutic applications in nuclear medicine. The program continues to receive widespread international recognition for the innovation of new, improved radiolabeling techniques and the design of tissuespecific agents for the evaluation of tissue metabo- lism, perfusion, and anatomy. Emphasis on research in cardiovascular disease has resulted in the development of radioiodinated fatty acid energy substrate analogues uniquely suited for evaluation of the early stages of heart disease. These agents are now being clinically tested. The new. improved osmium-191/iridium-191m radionuclide "generator" system producing iridium-191m $\left(T_{1 / 2}=5 \mathrm{~s}\right)$ for cardiovascular studies was awarded a patent, and marketing of this technology is being aggressively pursued. Interaction with over 25 medical coopierative programs with clinies, hospitals, and various other research institutions allows effective, rapid technology transfer to bring these agents into clinical use. A Center of Excellence in nuclear medicine is being proposed in conjunction with UT and Oak Ridge Associated Universities.

\section{Risk Assessment}

The Risk Assessment Program is focusing on an evaluation of the scientific bases for assumpticns used in the cancer risk assessment process. The cancer process can be separated into a pharmacokinetic phase and a pharmacodynamics phase. The former relates applied dose to effective dose at the target tissue, while the latter relates effective dose with biological effect. The program is evaluating the use of biologically based pharmacokinetic and pharmacodynamic models in risk assessment. 


\section{Program Accomplishments}

Accomplisinments in the Biomedical and Environmental Sciences programs include aqvances toward understanding potential health and environmental impacts of energy technologies and fundamental biological processes, as well as developing innova. tive research techniques and instrumentation. These research findings have resulted in numerous publications and awards (Tables $S$ and 6 ). Numbers and types of publications are presented in the Resource Quantitation chapter (see also Trimble et al. 1987).

The most significant biomedical and environmental research accomplishments are listed below by division. Editorial board memberships and offices held by Biomedical and Environmental Sciences personnel are presented in Tables 7 and 8, respectively. Research highlights for the OHER Program are included in Appendix A.

\section{Analytical Chemistry}

1. Resolution of 500,000 theoretical plates for the separation of nucleotides by micellar electrokinetic capillary chromatography has been achieved.

2. Wall-catalyzed oxidation reactions in conjunction with negative ion mass spectrometry were found to yield structural insight regarding the position of alkyl and amine substituents on aromatic ring systems.

3. Laser desorption Fourier transform mass spectrometry has allowed the mass spectra of modified nucleotides and small oligonucleotides to be obtained. Combined with MS/MS techniques, this approach has been used to distinguish six isomeric methyl-substituted guanosines.

\section{Biology}

1. Produced chromosome aberrations by introductivn of reatriction endonucleases into mammalian cells by osmolytic shock.

2. Used expression studies with dominant skeletal mutations to discover a strong effect of genetic background on penetrance, as well as to demonstrate interactions (both synergistic and antagonistic) between independent mutations.

3. Applied alkaline-elution techniques to mouse sperm DNA and demonstrated that the frequency of single-strand breaks induced in germ cells parallels that for certain transmitted genetic effects.

4. Prepared monoclonal antibodies that reach specifically with a glycoprotein marker on endothelial cells of the blood vessels of the mouse lung.

5. Demonstrated that the clinically useful antidiuretic amiloride and several analogs, known to function by preventing $\mathrm{Na}+$ and water reabsorption in the distal tubule of the kidney. have the further effect of inbibiting both $\mathrm{Na}+$ and glucose reabsorption in cloned cultured cells derived from the proximal tubule.

\section{Environmental Sciences}

1. Plutonium-238 releases from the Savannah River Plant have been used to show that coastal bays and estuaries serve as effective traps for radionuclides transported landward from oceanic sources as well as from landbased sources.

2. Three indices of pattern derived from information theory and fractal geometry have been 


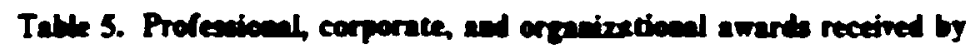

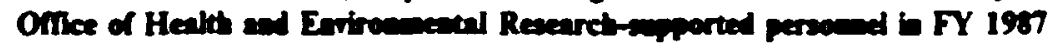

\begin{tabular}{|c|c|}
\hline Recipient(s) & Award \\
\hline Auerbach, S. I. & DOE Distinguisbed Aseocinte Award (1987) \\
\hline $\begin{array}{l}\text { Callook. T. A. and } \\
\text { E. T. Arakewa }\end{array}$ & $\begin{array}{l}\text { Martin Marietta Energy Systems, Inc, Inventor Award } \\
\text { (1986) for dexign, construction, and tering of a aew type } \\
\text { of soft X-ray emission spectrometer that is the most } \\
\text { efficient instrument of its type in the world }\end{array}$ \\
\hline $\begin{array}{l}\text { Chen, C.H., } \\
\text { S. D. Kramer, and } \\
\text { M. P. McCann }\end{array}$ & IR 100 Award, Crytal Leer Moaitor" (1987) \\
\hline Christophorou, L G. & $\begin{array}{l}\text { Martin Marietta Enerty Systems, Inc., Inventor Award (1986) } \\
\text { for continued, innovative developmeat of gaseous media } \\
\text { for advanced technologies that led to } 13 \text { patents and, } \\
\text { particularly, for the patents on repetitive pulsed- } \\
\text { power switches. }\end{array}$ \\
\hline Coutant, C. C. & $\begin{array}{l}\text { Society for Technical Communications Distinguished } \\
\text { Technical Communication Award (1987) } \\
\text { Technical Communication Award, East Tennessee Chapter } \\
\text { of the Society for Technical Communications (1987) }\end{array}$ \\
\hline $\begin{array}{l}\text { DeAngelis, D. L., } \\
\text { W. M. Post, and } \\
\text { C. C. Travis }\end{array}$ & $\begin{array}{l}\text { Martin Marietta Energy Systems, Inc, Publicacion Award } \\
\text { (1987) for Paritive Feedback in Natural Systems }\end{array}$ \\
\hline Gardnet. R. H. & $\begin{array}{l}\text { Martin Marietta Eneryy Systems. Inc. Technical } \\
\text { Achievemeat Award (1987) }\end{array}$ \\
\hline Griesemet, R. A. & Ohio State University. Distinguished Alumnus Award (1987) \\
\hline $\begin{array}{l}\text { Hartuan, F. C., } \\
\text { C. D. Stringer, } \\
\text { S. Milanez, and } \\
\text { E. H. Les }\end{array}$ & $\begin{array}{l}\text { Martin Marietta Energy Systems, Inc., Publication Award (1987) } \\
\text { - }\end{array}$ \\
\hline Hunsaker, $C . \mathrm{T}$. & $\begin{array}{l}\text { Association for Women in Science Aw-.d for Service to the } \\
\text { East Tennesece Chapter (1987) }\end{array}$ \\
\hline Kanciruk, $P$. & EPA Bronze Medal for Commendable Service \\
\hline King, A. W. & $\begin{array}{l}\text { University of Tennessee Chancellor's Citation for Extrzordinary } \\
\text { Professional Prnmise (1986) }\end{array}$ \\
\hline Knapp. F. F., Jr. & $\begin{array}{l}\text { ORNL Health and Safety Research Division Excellence in } \\
\text { Research Awand (1987) }\end{array}$ \\
\hline Lindbers. S. E. & $\begin{array}{l}\text { Alexander von Humboldt Research Fellowsiaip Award, } \\
\text { University of Gottingen (1987) }\end{array}$ \\
\hline $\begin{array}{l}\text { Lindberg, S. E, } \\
\text { G. M. Lovett } \\
\text { (Cary Arboretum), } \\
\text { D. D. Richtet } \\
\text { (Duke University), and } \\
\text { D. W. Johnson }\end{array}$ & $\begin{array}{l}\text { Martio Marietta Energy Systems, Inc., Publication } \\
\text { Award (1987) }\end{array}$ \\
\hline Luxmoore, R. J. & $\begin{array}{l}\text { Marin Marietta Energy Systems, Inz.. Technical Achievement } \\
\text { Award (1987) }\end{array}$ \\
\hline
\end{tabular}


Table $\subseteq$ (contined)

\begin{tabular}{|c|c|}
\hline Recipient(s) & Award \\
\hline \multirow[t]{2}{*}{ Olins, A. L. } & Eleanor Roosevelt International Cancer Fellowship (1987) \\
\hline & Theodor Boveri Award, University of Wurzburg (1987) \\
\hline \multirow[t]{2}{*}{ Olins, D. E. } & American Cancer Society, Scholar in Cancer Research Award (1987) \\
\hline & Theodor Boveri Award, University of Wurzburg (1987) \\
\hline O'Neill, R. V. & $\begin{array}{l}\text { Martin Marietu Energy Systems, Inc., Technical Achievement } \\
\text { Award (1987) }\end{array}$ \\
\hline Ramas, S. J. & $\begin{array}{l}\text { Martin Marietta Energy Systems, lac, Operational Performance } \\
\text { Award (1986) for organizing and leading a PIP team } \\
\text { that significantly reduced the probability of incortect } \\
\text { exclusion recommendations on property surveys at } \\
\text { Grand Junction, Colorado }\end{array}$ \\
\hline Reichle, D. E. & $\begin{array}{l}\text { Mariin Marietta Energy Systems, Inc., Community Service } \\
\text { Award (1987) }\end{array}$ \\
\hline \multirow[t]{2}{*}{ Russell, L. B. } & U.S. Department of Energy, Distinguished Associate A ward (1987) \\
\hline & Who's Who in America (1987) \\
\hline Sims, C. S. & $\begin{array}{l}\text { Martin Marietta Energy Systems, lnc, Operational Performance } \\
\text { Award (1986) for materially expanding the research } \\
\text { and technology transfer applications of the Health } \\
\text { Physics Research Reactor and for establishing } \\
\text { international leadership in neutron dosimetry }\end{array}$ \\
\hline Skinner, D. M. & $\begin{array}{l}\text { Women in Cell Biology, American Society of Cell Biology. } \\
\text { Career Recognition Award (1987) }\end{array}$ \\
\hline Srivastava, P. C. & $\begin{array}{l}\text { Martin Marietta Energy Systems, Inc., Inventor A ward (1986) } \\
\text { for development of an in:sovative approach for the brain- } \\
\text { specific delivery of dia juostic radiopharmaceuticals. }\end{array}$ \\
\hline Trabalka, J. R. & $\begin{array}{l}\text { Technical Communication Award, East Tennescee Chapter of } \\
\text { the Society for Technical Communication (1987) }\end{array}$ \\
\hline $\begin{array}{l}\text { Travis, C. C. } \\
\text { (Editor) }\end{array}$ & $\begin{array}{l}\text { Society for Technical Communication Award. Recognition of } \\
\text { Merit in Whole Periodicals (1987) for the publication } \\
\text { Risk Analysis }\end{array}$ \\
\hline Ullich, R. L. & Radiation Research Society, Research Award (1987) \\
\hline $\begin{array}{l}\text { Vo-Dinh, T., } \\
\text { M. J. Sepaniak, } \\
\text { B. J. Tromberg. } \\
\text { G. D. Griffin, and } \\
\text { K. R. Ambrose }\end{array}$ & I-R 100 Award. "Fiber-Optics Fluoroimmuno Sensor" (1987) \\
\hline Walton, B. T. & $\begin{array}{l}\text { Association for Women in Science for Distinguished and } \\
\text { Sustained Contributions to Science (1987) }\end{array}$ \\
\hline Yeh, G. T. & Martin Marietta Energy Systems, Inc., Publication Award (1987) \\
\hline
\end{tabular}




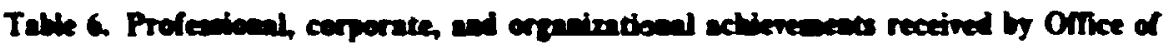

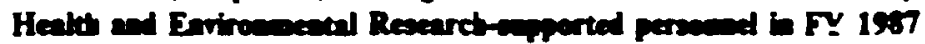

\begin{tabular}{|c|c|}
\hline Recipieat(s) & Achievemeat \\
\hline \multirow[t]{2}{*}{ Auerbach, S. 1 . } & $\begin{array}{l}\text { Appointed member of the Executive Committee, Science Advisory } \\
\text { Board, U.S. Environmental Protection Arency }\end{array}$ \\
\hline & $\begin{array}{l}\text { Appointed menber of the Committec on Magnetic Fusion, } \\
\text { Energy Engineering Board, National Academy of } \\
\text { Engineering }\end{array}$ \\
\hline Compros, R. N. & Corporate Fetlow. Martin Marietta Enery Systems, Inc (1987) \\
\hline Hively, L M. & $\begin{array}{l}\text { Full-time Advisor to Office of Enerty Research, Ofice of } \\
\text { Fusioa Energy. U.S. Department of Energy (1986-1987! }\end{array}$ \\
\hline Kaye, S. V. & $\begin{array}{l}\text { Fellow, American Arecintion for the Advancement of } \\
\text { Science (1987) }\end{array}$ \\
\hline Kert, G. D. & $\begin{array}{l}\text { Visiting Scientist, Radiation Effects Research } \\
\text { Foundation, Japan (September 1986-Auguar 1987) }\end{array}$ \\
\hline Knapp. F. F., Jr. & $\begin{array}{l}\text { Awarded Patent CNID 449. "Osmium-191/Iridium-191m } \\
\text { Radionuclide Generator" }\end{array}$ \\
\hline Kroodsma, R. L & Elective member, American Ornithologists' Union \\
\hline Payne, M. G. & $\begin{array}{l}\text { Awarded U. S. Pateat 4,694,197, "Double Pulsed } \\
\text { Time-of-Flight Mass Spectrometer" }\end{array}$ \\
\hline Ritchie, R. H. & Recipient, NATO Research Grant (1987-1988) \\
\hline Russell, L B. & Inducted into the National Academy of Sciences (1987) \\
\hline Severs, 1. & $\begin{array}{l}\text { Awarded U.S. Patent 4,633,082, "Process for Measuring } \\
\text { Degandation of Sulfur Hexalluoride in High-Volage } \\
\text { Systems" }\end{array}$ \\
\hline Turnet, $M$ & Fellow, Alexander Hollegader Distinguisbed Pastoctoral Fellowship \\
\hline Vo-Diah, $T$. & $\begin{array}{l}\text { Awarded Patent CNID 4532, -Practical Substrate and } \\
\text { Apparatus for Static and Continuous Moaitoring by } \\
\text { Surface-Enhanced Raman Spectroscopy" }\end{array}$ \\
\hline
\end{tabular}

shown to capture major features of landscape pattern, and one index is correlated with degree of human manipulation of the landscape.

3. Results from Walker Branch wat irsted on the mechanisms and rates of calcium try deposition have been selected by EPA fo - application to a large-scale study of lake a idification for the National Acid Precipitation ، ssessment Program.

4. Isotopic studies of sulfur dynamics in trees on Walker Bran:h watershed have shown thit leaching of internal foliar $S$ from tree leaves by rainfall is a minor component of throughfall sulfate: therefore, the dry deposi- tion (gaseous and particulate) of $S$ to forests impacted by sulfur pollution may be estimated from measurements of sulfate in throughfall.

5. ORNL hosted an international meeting fo: DOE's Subsurface Transpor Program. Scientists attending the meeting concluded that ample evidence exists to show that colloidal particles in aquifers are capable of binding organic and inorganic contaminants and altering their mobility in the subsurface environment.

6. The United States and the People's Republic of China (PRC) signed a joint agreement to study global climate change. Communications links for Jata exchange have been enhanced 


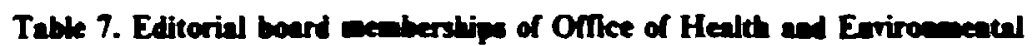
Researct-sepported personed hine FY 1987

\begin{tabular}{|c|c|}
\hline Board member & Publication \\
\hline Adams, S. M. & Biological Communities of the Southeastem United States (1985-) \\
\hline Adier, H. I. & Radiation Research, Aseociate Editor (1980-1987) \\
\hline Auerbach. S. I. & $\begin{array}{l}\text { Environmensal and Experimenual Botany (1967-) } \\
\text { Environmental Insernational (1979-) }\end{array}$ \\
\hline Bondietti. E. A. & Journal of Enviranmental Radioactivity. Associate Editor, (1983-) \\
\hline Buchanan. M. V. & $\begin{array}{l}\text { Biomedical and Environmental Mass Spectrometry (1986-1990) } \\
\text { Fourier Transform Mass Spectrometry: Evolution, Innovation and Applications. ACS Books, } \\
\text { Editor (1987-) }\end{array}$ \\
\hline Cook. J. S. & $\begin{array}{l}\text { American Joumal of Physiology, Associate Editor (1981-1987), Acting Editor (1984-1985) } \\
\text { Cell and General Physiology, American Pbysiological Society Handboot Series, (1982-present) } \\
\text { Current Topics in Membranes and Transport, Advisory Board (1983-present) } \\
\text { News in Physiological Sciences, Editorial Board (1985-1986), Deputy Editor (1986-1988) }\end{array}$ \\
\hline Coutant, C. C. & Transactions of the American Fisheries Saciety (1986-) \\
\hline Eckermen, K F. & Radiation Protection Dasimetry Joumal Editorial Board Member. (1980-present) \\
\hline Generoso, W. M. & $\begin{array}{l}\text { Teratozenesis. Carcinogenesis, and Mutagenesis (1979-present) } \\
\text { Mutation Research (1985-1988) } \\
\text { Molecular Toxicology (1987-present) }\end{array}$ \\
\hline Hamm, R. N. & Radiation Research, Associate Editor (1985-1988) \\
\hline Hartman, F. C. & $\begin{array}{l}\text { Journal of Protein Chemistry (1982-1992) } \\
\text { Journal of Biological Chemistry }(1983-1988)\end{array}$ \\
\hline Hunsaker, C. T. & The Environmenual Professional (1986-) \\
\hline Johnson, D. W. & Joumal of Environmental Quality. Associate Editor (1985-) \\
\hline Kimmel, B. L. & $\begin{array}{l}\text { Lake and Reservoir Manogemens (1986-) } \\
\text { Limnology and Oceanography (1987-1990) }\end{array}$ \\
\hline Klots, C. E. & Intermational Joumal of Mass Spectrometn' and Ion Physics Associate Editor (1983-present) \\
\hline Lindberg. S. E. & Advances in Environmental Sciences (1986-) \\
\hline Luxmoore. R. J. & $\begin{array}{l}\text { Soil Science Society of America Journal. Associate Editor (1986-) } \\
\text { Tree Physiology. Aswociate Editor (1986-) }\end{array}$ \\
\hline Mazur, $P$. & Cryobiology (1967-present) \\
\hline Norby, R. J. & Tree Physiology (1987) \\
\hline Olins, A. L. & $\begin{array}{l}\text { European Journal of Cell Biology (1982-present) } \\
\text { Molecular and Cellular Biochemistry (1982-1985) }\end{array}$ \\
\hline Olins, D. E. & Molecular and Cellular Biochemistry (1983-1986) \\
\hline Preston, R. J. & $\begin{array}{l}\text { Mutation Research (1977-present) } \\
\text { Emvironmental and Experimental Botany (1979-present) } \\
\text { Mutation Research Letters, Managing Editor (1980-present) } \\
\text { Teratogenesis, Carcinogenesis, and Mutagenesis (1980-present) }\end{array}$ \\
\hline Regan, J. D. & Cell Biology and Toxicology (1983-present) \\
\hline Reichle, D. E. & $\begin{array}{l}\text { Pedobiologia (1975-) } \\
\text { Journal of Soil Biology and Ecology (1987-) } \\
\text { Advanced Texts in the Life Sciences. Series Editor. Springer-Verlag (1978-) }\end{array}$ \\
\hline
\end{tabular}


Talle 7 (coodinad)

\begin{tabular}{|c|c|}
\hline Board member & Publication \\
\hline Russeli. L. B. & $\begin{array}{l}\text { Mutation Research (1976-present) } \\
\text { Mouse News Letter (1986-) }\end{array}$ \\
\hline Segn, G. A. & Enviranmental Mutagenesis (1985-) \\
\hline Skinner, D. M. & $\begin{array}{l}\text { Growh (1979-present) } \\
\text { Gene (1986-present) }\end{array}$ \\
\hline Smith. E D. & Nuclear Sofety, Enviroamental Effects Section Editor (1985-) \\
\hline Stow, S. H. & Environmental Geolozy and Water Resources (1984-) \\
\hline Suter, G. W. & $\begin{array}{l}\text { Environmental Toxicology and Chemistry (1987-1989) } \\
\text { SETAC News. Associate Editor }\end{array}$ \\
\hline Travis, C. C. & Risk Analysis. Editor-in-Chief (1983-present) \\
\hline Ullich, R. L. & Radiation Research (1983-1989) \\
\hline Van Hook. R. I. & Biomass. Aseociate Editor (1985-) \\
\hline Wascon, A.P. & Environmental Management, Book Review Editor (1984-present) \\
\hline Witherspoon. J. P. & Nuclear Safery, Eovironmental ErTects Editor (1983-) \\
\hline Yaicintas, M. G. & $\begin{array}{l}\text { Biology and Medicine Division Newsletter American Nuclear Society, Editor } \\
\text { (1985-present) }\end{array}$ \\
\hline
\end{tabular}

by Carbon Dioxide Information Analysis Center-designed computerized data acquisition and certification systems and by interactions with visiting PRC scientists.

\section{Health and Safety Research}

1. Developed, constructed, and installed at the National Synchrotron Light Source a new type of soft X-ray emission spectrometer that is the most efficient instrument of its type in the world.

2. Obtained first observation of optically enhanced electron attachment.

3. Obtained first identification of multiphoton ionization mechanisms in liquids.

4. Developed two electron scanning-tunneling microssopes and obtained atomic resolution of solid surfaces in ultrahigh vacuum and in air.

5. Documented extensive work to produce a single set of predicted urinary excretion rates consistent with available physiologic and metabolic information, which significantly increases the accuracy of estimates of plutonium body burdens from bioassay measure. ments.

6. Contributed to formulation and documentation of a new nuclear radiation dosimetry system. DS86. The new system resulted from a joint, seven-year U.S.-Japan dosimetry reassessment effort.

7. Constructed a computerized axial tomography (CAT)-scan imaging workstation, centered around an IBM PC/AT, for processing data acquired under normal medical diagnostic procedures. The data obtained is being used to establish digital representations of the body for use in radiation transport calculations.

8. Developed a physiologically based pharmacokinetic model for metabolism of methyl chloroform in mice, rats, and humans.

9. Developed a new lechnique for conducting two-photon spectroscopic studies of high-lying molecular energy levels. The method involves the use of the ninth harmonic of an Nd:YAG laser plus a tunable dye laser to efficiently access states with energy $>10 \mathrm{eV}$. 
Talke 8. Oricers of societies anong Ofitice of Health and Environental Research-somported personed deriag FY 1987

\begin{tabular}{|c|c|}
\hline Oftrcer & Office, Society \\
\hline Berven, B. A. & $\begin{array}{l}\text { Chairman, Environmental Section of the Health Physics Society Standards Committee } \\
\text { (1985-present) }\end{array}$ \\
\hline Buchanan, M. V. & $\begin{array}{l}\text { Advisory Committee, National Science Foundation, Biological Facilities Center } \\
\text { Propram } \\
\text { Chairman, Enviroameatal Applicatioas Group, American Society for } \\
\text { Mas Spectrometry } \\
\text { Councilor, Eart Tennessee Mass Spectrometry Discussion Group }\end{array}$ \\
\hline Chester, R. 0. & $\begin{array}{l}\text { Member. Executive Committec of the Environmental Sciences Division, } \\
\text { American Nuclear Society (1985-1988) }\end{array}$ \\
\hline Compron, R. N. & $\begin{array}{l}\text { Executive Committee Member, Division of Electron and Atomic Physics, } \\
\text { American Physical Society (1984-1987) }\end{array}$ \\
\hline \multirow[t]{2}{*}{ Coutant. C. C. } & President, Soutbern Division, American Fisheries Society (1987) \\
\hline & President, Tennescee Chapter, American Fisheries Society (1987) \\
\hline Cristy, M. T. & $\begin{array}{l}\text { Vice-Chairman. Task Group on Revision of Reference Man, Committec } 2 \text { on } \\
\text { Secondary Limits, Intermational Commission on Radiological Protection } \\
\text { (1984-present) }\end{array}$ \\
\hline Cushman, J. H. & President, East Tennessee Chapter, Association for Women in Science (1985-1986) \\
\hline Eckerman, K. F. & $\begin{array}{l}\text { Chairman. Task Group on Dose Calculations, Committec } 2 \text { on Secondary } \\
\text { Limits, International Commission on Radiological Protection } \\
\text { (1982-present) }\end{array}$ \\
\hline Foley, R. D. & Iteasuret, East Tennessec Chapter, Health Pbysics Society (1986-) \\
\hline Gammage, R. B. & $\begin{array}{l}\text { Chairman, Indoor Air Quality C(mmittee, Americas Industrial Hygiene } \\
\text { Aseociation (1987-1988) }\end{array}$ \\
\hline Graham, R. L. & $\begin{array}{l}\text { Vice President, East Tennewce Chapter, Association for Womea } \\
\text { in Science (1987-1988) }\end{array}$ \\
\hline Huff, D. D. & Presidenc. Tennesuee Section of the American Institute of Hydrology \\
\hline Lindberg, S. E. & $\begin{array}{l}\text { Secretary, National Atmespheric Deposition Program } \\
\text { Member, Executive Committec, National Atmospheric Deposition Program }\end{array}$ \\
\hline Little, C. A. & $\begin{array}{l}\text { Chaiman. Awards Subcommittee, Manpower and Professional Education } \\
\text { Committee, Health Physies Society (1986-1987) }\end{array}$ \\
\hline Mazur, $\mathrm{P}$. & $\begin{array}{l}\text { Board of Goveraon, Society for Cryobiology (1981-1987) } \\
\text { Chairman, Publications Committee. Society for Cryobiology (1974-) }\end{array}$ \\
\hline Preston, R. J. & Chairman, Nominatiog Committee, Environmental Mutagen Society (1986-) \\
\hline Ramsey, R. S. & Program Chairman, East Tennessee Chromatograpby Discussion Group \\
\hline Reichle, D. E. & $\begin{array}{l}\text { Chairman, Public Affairs Comnittee, Ecological Society of America } \\
\text { Member, National Board of Governon, The Nature Conservancy (1982-) } \\
\text { Member, Governing Council, Ecological Society of America }\end{array}$ \\
\hline Ritchic, R. H. & Member, Executive Committee, Southeastern Section. Américan Physical Society \\
\hline Sigmon, C. F. & Treasurer, East Tennessee Chapter. Association for Women in Science (1987-1988) \\
\hline Sims, C. S. & $\begin{array}{l}\text { Chairman. ANSI N13.11 Review Working Group. Health Physics Society } \\
\text { (February 1987-present) }\end{array}$ \\
\hline
\end{tabular}


Talle 8 (coutinad)

\begin{tabular}{|c|c|}
\hline Otficer & Ofice. Society \\
\hline Skinner, D. M. & Board of Governors (North America), The Crustaceen Society (1987-) \\
\hline Solomon. A. M. & Chairman. Education Committer. Ecolopical Society of America (1983-) \\
\hline Stow, S. H. & $\begin{array}{l}\text { Secretary-Treasurer, Southeastern Section, Geological Society of America (1980-1987) } \\
\text { Councilor, Geological Society of America (1986-1989) }\end{array}$ \\
\hline Swaja, R. E & $\begin{array}{l}\text { Chairman, ASTM E10.04 Committee on Criticality Accident Dosimetry } \\
\text { (1986-present) }\end{array}$ \\
\hline \multirow[t]{2}{*}{ Travis C. C. } & $\begin{array}{l}\text { Chairman, Scientific Bases for Risk Arearment Assumption, Office of Science } \\
\text { and Technolony Policy (1986-present) }\end{array}$ \\
\hline & President-elect, Socjety for Risk Analysis, East Tenoessee Chapter (1987-1988) \\
\hline Trimble, J. L. & Prevideat, East Tennesuee Chapter, Aseociation for Women in Science (1987-1988) \\
\hline \multirow[t]{3}{*}{ Vo-Dinh, $\mathrm{T}$. } & Cochairmen International Committee on Polycyclic Aromatic Compounds (1985-present) \\
\hline & $\begin{array}{l}\text { Secretary, Technical Committee TT-6 on Enerzy-Environsental Interactions, } \\
\text { Air Pollution Control Aseociation (1984-present) }\end{array}$ \\
\hline & $\begin{array}{l}\text { Program Chairman, Air Pollution Coatrol Association, East Teanesser } \\
\text { Chapter (1987-present) }\end{array}$ \\
\hline Waltoon, B. T. & Boand of Directors, Society of Environmental Toxicology and Chemistry (1984-1987) \\
\hline Wright, L L & Secretary, East Tendeasee Chapter, Aswociation for Women in Science (1986-1988) \\
\hline \multirow[t]{2}{*}{ Yalcintas, M. G. } & $\begin{array}{l}\text { Chairman, Organ Dose Committee, Biology and Medicine Division, } \\
\text { American Nuclear Society (1980-prenent) }\end{array}$ \\
\hline & $\begin{array}{l}\text { Chairman, Protram Committec, Biolosy and Modicine Division. American Nuclear } \\
\text { Society (1984-present) }\end{array}$ \\
\hline
\end{tabular}

10. Showed how a two-photon interference effect produced a new and comprehensive explanation for low efficiencies of four-wave mixing schemes for ultraviolet light production in which two-photon resonances are used to enhance the yields of ultraviolet photons.

11. Initiated clinical testing of the new iodine123-labeled, methyl-branched, fatty acid agent for evaluation of heart disease.

12. Developed a new radioiodinated-maleimideprotein-labeling method for the radioiodina- tion of antibodies and other proteins, which overcomes the problems associated with loss of iodide encountered with current methods.

13. Further developed fluoroimmunosensor technology, using laser excitation, which results in an absolute limit of detection of femtomoles $10^{-15}$ for benzopyrese and attomoles $10^{-18}$ for benzo(a)pyrene tetrol.

14. First demonstrated that calcium atoms of the periodic chart form stable negative ions in their electronic ground state. 


\section{Program Orientation}

The ORNL/OHER budget proposal for

FY 1987-1990 is summarized in Table 9. Budgets for FY 1988 and FY 1989 are expected to increase above tiese initial planning estimates. Significant planned activities summarized by division follow.

\section{Biology}

During the past several years, a major consolidation of effort has taken place to strengthen and focus the division's research program on experimental genetics. The effort, which started prior to FY 1987 to integrate significant molecular genetics initiatives into the mammalian genetics program, will continue in FY 1988 and FY 1989. By FY 1989 and beyond, our work with modern molecular tools such as insertional mutagenesis will be well established. The program in radiation carcinogenesis will be maintained, contingent on the availability of the Health Physics Research Reactor for neutron irradiations and the Biology Division's ${ }^{137} \mathrm{Cs}$ sources. Expected trends in molecular genetics research in the new initiative in protein engineering and in radiation carcinogenesis are briefly described below.

The Mammalian Genetics Program, in addition to pursuing several exciting discoveries growing out of germ-line mutagenesis studies, is embarking on a long-range activity to gain molecular access to several regions of the mouse genome. The objectives are to explore the structural nature of induced mutations and of the normal DNA from which they arose, to identify hitherto unknown genes and gene products that are important for normal mammalian development, to correlate defined DNA sequences with physiologically significant heritable types, and to directly analyze the structure and function of homologous regions of the human genome. The major genetic tools for achieving these objectives are a series of overlapping deletions, derived from past mutagenesis studies, that have already been utilized for the construction of functional maps in chromosomal regions of considerable length. Consequently, after molecular chromosome mapping within these regions has been achieved, the outcome need not stand alone as a sterile catalog; it can be readily associated with the functional information. To aug. ment the structure-function correlations, saturation mutagenesis experiments have also been initiated that will load the regions corresponding to the long deletions with point mutations or very small deletions. In a related but independent effort, a project of insertional mutagenesis is planned in which

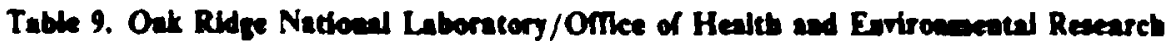
balget and enteoutrects (thomands of dollars)

\begin{tabular}{|c|c|c|c|c|}
\hline Budget & FY 1987 & FY 1988 & FY 1989 & FY 1990 \\
\hline $\begin{array}{l}\text { Total ORNL/OHER in-house } \\
\text { budget }\end{array}$ & 22,866 & 22,648 & 23,602 & 25,038 \\
\hline Total subcontracts & $2.861(11.19)^{\circ}$ & $2,925(11.496)^{a}$ & $2.975(11.18)^{\circ}$ & $3.100(11.008)$ \\
\hline Total OP.NL/OHER budget & 25.727 & 25.573 & 26.577 & 28.138 \\
\hline
\end{tabular}

aPercent of total OR NL/OHER budget. 
mutations will be induced by the integration of exogenous DNA introduced into the male pronucleus of the fertilized egg. Once such mutations have been recovered, the disrupted regions of DNA are readily analyzable by virtue of the integrated foreign sequences.

Among the mutagenesis studies in progress are several areas that are receiving special emphasis. The extreme sensitivity of the zygote to a unique combination of endpoints is being intensively investigated in cyrogenetic and developmental analyses. Collaborative studies were initiated to explore whether chesicals ean bring about mutations by stimulating insertion of transposable elements. Other areas of emphasis include the basic mecha. nisms underlying correlations between dominant phenotypes (which are highly important for risk considerations) and presumed balance chromosome rearrangements and other aberrations; the use of isolated specific germ-cell types for the detection of potentially transmissible genetic damages; study of adduct locations in chromatin to illuminate the basis for dose-rate effects and for stage-related seasitivities; and the use of X-autosome translocations as tools for studies of gene action, chromosomal synapsis, genome mapping, and the deriva. tion of DNA libraries enricbed for desired chromosomal segments.

Protein engineering, a new initiative in 1985, has made significant strides. Protein engineering utilizes recombinant DNA technology to systematically change protein structure, thereby providiag a powerful tool for elucidating enzyme mechanisms and potentially for altering the properties of enzymes in predictable and desirable fashions. The two major objectives were to establish this Dewly emerging experisse within the Biology Division and to subsequently appiy this expertise to questions concerning the mechanism of action of proteins relevant to DOE missions. Initiated with partial support from ORNL's Laboratory Director's R\&D Fund, this program represents a collaborative effort that involves eight senior staff members of the Molecular Genetia Section (Biology Division) and integrates activities in biochemistry and molecular genetics. Research is focusing on the structure/function cortelations of three proteins: ribulose bisphosphate carboxylase (a determinant of biomass yield), DNA- $\sigma^{6}$-methylguanine methyltransferase (a DNA repair enzyme), and human epidermal growth factor (a polypeptide that regulates cell growth and differentiation).

Ubiquitous among photosynthetic organisms, ribulose bisphosphate carboxylase (Rubiscu) is essential for net conversion of atmospheric $\mathrm{CO}_{2}$ into carbohydrates. Thus, this enzyme is a major cornerstone of living processes and is highly relevant to the production of biomass for energy and to the global $\mathrm{CO}_{2}$ issue (i.e., the greenhouse phenomenon). The enzyme is bifunctional. Although multiple substrate specificities among enzymes are not unusual, the bifunctionality of Rubisco is perbaps unprecedented in that the two reactions catalyzed are the initial steps in competing metabolic pathways - photosynthetic assimilation of $\mathrm{CO}_{2}$ and photorespiration, the latter of which is an energy-wasteful process witbout a knowa function that results in the release of previously fixed $\mathrm{CO}_{2}$. The objectives of site-directed mutagenesis studies are (1) to understand the mechanism of this complex enzyme, especially the roles of specific amino acids and domains in interaction with substrates and in mediating the discrete catalytic steps, and (2) to evaluate the feasibility of improving the carboxylase/oxygenase activity ratio and thereby provide an approach to enhancing biomass yields. A large number of Rubisco mutants have been constructed in which specific amino acids within the catalytic site have been replaced by other amino acids. Characterization of these mutant proteins has provided insights into the precise catalytic roles of the essential amino acids.

DNA- $\sigma^{6}$-methylguanine methyltransferase is an enzyme that repairs mutagenic lesions in DNA caused by a variety of environmental chemicals. Specific structural aiterations have been introduced into this enzyme by site-directed mutagenesis to explain the process of alkyl-group transfer between the DNA and protein. Insights into the regulation of gene expression for this repair enzyme are also being gleaned.

The involvement of extraceilular protein factors in the regulation of DNA replication, specific RNA synthesis, and cell division has long been recog. nized. Several factors have been isclated with the ability to stimulate the growth of cells and the expi:esion of specific genes believed to be involved in the entrance of mammalian cells into and progression through the cell cycle. One of the most 
highly studied among these is epidermal growth factor (EGF), a 6-kDa single polypeptide chain with three internal disulfide bonds, which is known to initiate its action through high-affinity binding to the specific cell surface EGF receptor. In response to EGF, the receptor undergoes autophosphorylation on tyrosine residues by its intrinsic protein kinase activity besides phosphorylation of exogenous substrates. Despite the variety of functions elicted in response to EGF, little is known about the biochemical mechanisms by which EGF activates the receptor's tyrosine kinase activity. stimulates the internalization of the EGF-receptor complex, and eventually stimulates DNA replica. tion and specific RNA synthesis and cell division. The major objective of the research is to identify the amino acid residues in EGF that are recessary for (1) its binding to the EGF receptor, (2) stimulation of the EGF receptor protein binase activity, and (3) stimulation of the growth of quiescent cells.

During the past year, the gene for human EGF was assembled from DNA fragments synthesized in an automated DNA synthesizer and cloned into Escherichia coli to generate the product as a bacteria! secretory protein. The recombinant protein was purified to homogeneity and found to be identical in structure and function to authentic human EGF. Structure-function analysis by site-directed mutagenesis was initiated at several sites of EGF based on its solution structure, the amino acid residues conserved through evolution, and studies with fragments of EGF. The results have shown that tyrosine-37, arginine -41 , and leucine -47 are in regions of the molecule that are critical for its binding to the EGF receptor.

Ongoing work on neutron carcinogenesis, heavy-ion carcinogenesis, and UV carcinogenesis in whole animals and in the in vivo-in vitro model systems will continue. In addition, new studies are planned (depending on the availability of funds) on radon and related high-LET radiations that include (1) alpha-particle activation of oncogenes, (2) gene rearrangement involving mobile gene elements, (3) induction of chromosome aberrations, (4) malignant transformation of tracheal cells, and ( 5 ) determination of the relative biological effectiveness for alpha-particle-induced cancers. Future work will also involve the question of whei. ir specific radiation-induced chr mosome aberrations are carsally related to the induction of myeloid leukemia, mammary cancer, and fibrosarcomas. The pertinent molecular changes that result from the chromosome aberrations will be determined.

During the past year, the information research and analysis efforts bave focused on validation, aralysis, and application of data resources in areas related to the potential health and environmental effects of hazardous substances. Under a multiyear task with the Department of the Army, water quality criteria are being defined for Army-relevant chemicals. To date, three finished reports and four draft reports have been prepared. The data base that was assessed in a study of hexabydro1,3,5-trinitro-1,3,5-triazine (RDX) shows some indication of carcinogenic potential; however, the available data were not sufficient to be more definite. Recommendations were made for additional research to fill in the existing cata gaps. The findings of the report were used to asseas the potential toricity of RDX-contaminated well water in a Nebraska community. The contamination "as assumed to have originated from a nearby Army ammunition plant. An additional study for the Army focused attention on the carcinogenic potential of 2,6-dinitrotoluene (2,6-DNT). It was determined that the reported carcinogenicity of 2,4-dinitrotoluene was in reality due to contamination with the 2,6 isomer.

The evaluation and development of chemical scoring systems is an ongoing task. A scoring system was designed to assist the Environmental Protec. tion Agency (EPA) in identifying chemicals needing further review, testing, or regulatory action. Two EPA reports and two journal articles (the most recent is in draft form) have highlighted this effort. The system was developed for the Office of Toxic Subsiasces and bas been used in modified form for the Coffice of Air and Radiation and the Office of Solid Waste. Current efforts are focused on the Office of Policy, Planning, and Evaluation and their need for a weight-of-evidence ranking system.

The first phase of the EPA Gene-Tox Program has consisted of the evaluation of 72 specific short-term bioassays for mutagenicity and the development of an accompanying data base on the chemical induction of tumors in laboratory animals. The purpose was to select an appropriate battery of tests for determination of mutagenicity and the possible correlation between mutagenicity 
and carcinogenicity. This literature was acquired, initially screened, and made available to the GeneTox work groups by the Environmental Mutagen Information Center and primarily encompassed the period 1969-1979. This work resulted in the formation of an evaluated data base of 2724 unique chemical agents. Updating some assay systems through a portion of 1986 brought the data base to almost $\mathbf{4 0 0 0}$ chemicals. Each of the 37 papers published to date includes carcinogenicity data where available.

The second phase of the EPA Gene-Tox Program, a plan to summarize this information and make recommendations and correlations, is in process but is not complete. Analysis of the sensitivity of specific assays for particular classes of compounds is being conducted. Ten bioassays have been defined as routine. These cross several phylogenetic levels and include both in vivo and in vitro procedures. They include analysis for reverse mutation, direct DNA damage, sex-linked lethal gene mutation, chromosome aberrations, chromosome alterations, and germ cell damage. Coverage of all types of genetic damage can be obtained by using a battery of these tests. The estimated price per test and performance period bas been determined.

\section{Environmental Sciences}

In ORNL's OHER environmental research prograrn. decreased funding is anticipated during the next several years. Research has been consolidated into investigations of integrated watershed processes. Studies designed to increase the understanding of the mechanisms whereby the environment modifies contaminants and how such materials move through and affect the receiving ecosystems are receiving emphasis.

Basic ecological research in aquatic and terrestrial systems in the Southeastern and Appalachian regions is being maintained. Research on landscape systems analysis, focusing on quantification of landscape patterns and on investigation of relationships between pattern statistics and environmental processes continues. Use of remote sensing for regional evaluation of factors sucb as land use, pollution damage, vegetation cover, vegetation productivity, geology, and hydrology and for testing and developing hypotheses concerning landscape dynamics and structure is increasing. The under- standing developed in such studies continues to be valuable input for assessing the potential ecological effects associated with the future development proposed for this region.

Research capabilities related to nuclear technologies were redirected. Emphasis will continue to center on chronic releases and the long-term behavior of the radionuclides in typical Eastern environments. Radio tracers ${ }^{35} \mathrm{~S}$ and ${ }^{7} \mathrm{Be}$ are being used to investigate the biogeocbemical cycling and ecologic phenomena that govern element transport in forest ecosystems. Expertise is being developed in geosciences to conduct research more effectively and to analyze waste management issues.

Continued development in environmental chemistry and efficient utilization of simulation modeling will provide more accurate predictions concerning transport, fate, and ecological effects of organic contaminants. This research provides technology transfer to the site-specific Remedial Action Programs at all Oak Ridge facilities. The extension of this research toward new applications in environmental risk analysis is being pursued.

Research in earth sciences related to energy residues will emphasize geology, hydrology, and environmental chemistry. These areas will continue to emphasize research on contaminant transport in the geosphere. The emphasis will include research on mechanisms of sorption/desorption with host media, with continuing development of analytical capabilities to predict the mobility of contaminants in these systems. Analysis of regional landscapes is emphasizing the development of new mathematical approaches for quantifying spatial patterns in terms of physical and biological attributes.

During the past year, there has been a significant effort to address the potential transport and effects of atmospheric contaminants on aquatic ecosystems. Emphasis has been placed on understanding the interactions between terrestrial and aquatic ecosystems and integrating the appropriate expertise available at the various DOE facilities. ORNL will continue to develop and demonstrate approaches for quantifying ecological response to environmental stress at regional land:cape scales.

During the next five years, Carbon Dioxide Research Program activities will encompass new research in terrestrial/aquatic carbon dynamics 
and global carbon cycle modeling, as well as new responsibilities in carbon cycle research management for DOE. The principal purpose of this program is to provide assistance to the Division of Carbon Dioxide Research in development, management, and research activities. In carrying out this ta: $k$, the program is responsible for monitoring research progress of ORNL subcontracts, DOE contracts, and in-bouse projects; identifying research needs to support global carbon cycle model development: and recommending methods for fulfilling these needs. The monitoring involves preparing and updating multiyear research plans for DOE.

The ORNL staff executes and administers subcontracts to universities and major research institutions for new or continuing research supporting the Carbon Dioxide Research Program, concentrating on model development and oceanic and terrestrial biospheric data acquisition. The ORNL staff prepares technical and topical reports to update research progress, to provide responses to specific questions, and to resolve technical issues. The CDIAC continues to broaden its efforts in support of the international $\mathrm{CO}_{2}$ research community.

\section{Health and Safety Research}

Health and safety research develops new experimental and theoretical methods and improves methods for assessing human health impacts of energy technologies. Activities include studies of interactions of potentially bazardous agents with biological and environmental systems and ensuring a technical capability for characterizing and quan. titatively measuring such agents in various settings. Long-range goals include identification of effective steps toward the amelioration of potential health and environmental risks associated with new and existing technologies. This program consists of studies involving the structures and properties of materials of biological or environmental importance; the physical and chemical mechanisms that govern transport and clsemical transformations of pollutants in the atmosphere, hydrosphere, and biosphere; and the details of direct interactions of harmful agents with biological materials.

In physical and technological programs, emphasis on elucidation of physical mechanisms underlying formation and interactions of hazardous agents associated with various energy technologies is continuing. Particular attention will be given to processes occurring on surfaces of solids and liquids and on the use of state-of-the-art laser techniques for detecting and characterizing a wide variety of chemical species. A major new initiative involves implementation of a picosecond laser program for studies of fast chemical processes including early chemical steps in irradiated biological materials, behavior of radicals in liquids and gases, and nonlinear optical phenomena. A major commitment of capital equipment toward this project was made in FY 1987. A second commitment of similar magnitude will be required in FY 1988.

A growing emphasis will be placed on combined physical, chemical, and biological research directed at iundamental chemical dosimetry and dose concepts that are relevant to human health protection. One focus will be on events occurring at the ultimate target riolecule or cell. Current work has involved studies of the binding of electrophiles, such as toxic metal ions, to basic sites of target RNA and DNA molecules. Research will be expanded to include organic adducts, disiorted conformation, and changes in gene expression. The active ongoing collaboration between the Health and Safety Research and Biology divisions will continue and be expanded to incorporate newly initiated experimental studies that will contribute to OHER's human genome initiative. A newly initiated program uses scanning-tunneling microscopes capable of single-atom resolution. Emphasis will be placed on studies of the structures of biological systems including the human genome.

Research will also include methodologies and devices that can be used for problems relating to hazardous chemical wastes, fugitive emissions, exposure monitoring (including skin biological monitoring), and chemical dosimetry. Existing portable instruments and cost-effective monitoring techniques will become more focused on analyzing workplace samples in ways that reflect the degree of potential hazard to the worker. Clinicalbiological as well as exposure-monitoring techniques will be included. These activities will require concomitant studies of the nature of fugitive emissions vis-à-vis process stream materials and field characterization of hazardous chemical wastes. Parallel research will be conducted to develop dosimetry concepts at both the applied and 
fundamentai ieveis. Several of these projects will be carried out jointly with the Analytical Cbemistry, Biology, and Environmental Sciences divisions.

A continuing research activity is the development of new instruments and measurement techniques to support evaluation of the potential bealth and environmental impacts of developing energy technologies. Results of this research have led to costeffective luminescence techniques for rapid screening of samples containing polynuclear aromatic compounds as well as portable instrumentation for on-site use at operating facilities. The OHERfunded deveiopmental research has resulted in support from other agencies and organizations for applied studies. Transfer of this technology to the commercial sector is an important objective.

An increased effort is being made to wtablish a viable program in risk analysis. Part work has focused on developing methodologies to quantify exposure and the impact of environmental pollutants on human health. These methods have been applied to characterize the risk from direct coal liquefaction facilities, liquid-metal fast breeder reactors, hazardous waste incineration, and extralow-frequency electromagnetic fields. Methodology development in risk analysis is concentrating on low-dose and interspecies extrapolations and pharmacokinetic modeling. Potential growth areas inciude several areas of national concern: hazardous waste management, groundwater pollution, and bealth effects of biotechnology. Success in attracting funding in these areas will depend on our ability to combine the Health and Safety Research Division's diverse areas of expertise to provide new insights into both applied anc' methodological risk analysis issues.

Information research and analysis activities in support of various government agencies (EPA, NIH, $D O D$, and DOE) hove been carried out since the early 1970s. These activities focus on validation, analysis, and application of data resources in research areas related to the potential bealth and environmental effects of hazardous substances. Development of validated health effects data bases is a continuing endeavor. The Hazardous Substances Data Bank now contains more than 4500 records, each consisting of 140 data fields describing specific attributes of specific chemicals. The Gene-Tox Database consists of data validated by 23 expert panels which evaluated 74 short-term bioassays for determining the mutagenic potential of chemical substances. The initial work (including data through 1979) resulted in an evaluated data base of 2724 unique agents, and updating through 1986 brought the total to about 4000 chemicals. The genetic data and expertise developed by this work since 1969 within the Environmental Mutagen Information Center has potential for a strong supporting role in the DOE Human Genome Program. Additionally, the Fossil Energy Safety, Health and Environmental Information Systems provides a framework for integrating many data bases pertaining to various aspects of power plant operations and environmental concerns.

These and many other data resources sn topics such as acid precipitation, remedial actions. environmental teratogens, and environmental carcinogens provide a strong base for the preparation of numerous assessment reports by the scientific staff of the Laboratory. Such resources can also play a major role in risk analysis.

Indoor air quality research is focusing on radon entry and mitigating effectiveness. Our broadbased assessment of this compiex exposure problem has been suppiemented by new studies focused on reduction of dosimetric and risk uncertainties. Such studies may lead to better exposure guidance.

A long-term division activity has been the de in $^{-1}$ ment and evaluation of new -adiopharmaceuticals for diagnostic and therapeutic applications in nuclear medicine. Major emphasis is on the development of agents for the evaluation of heart disease, cerebral blood flow, and regional evalua. tion of tissue metabolism. Tissue-specific agents, such as our recently labeled fatty acids, have prov. en to be valuable additions to the field. Clinical evaluations are currently under way using distributions of radiolabeled agents through our Medical Cooperative Program. New emphasis will be placed on protein labeling activities, development of a rhenium-188 radionuclide generator, and collaborative studies with The University of Tennessee to develop new radiolabeled, tissue-specific agents using positron emission tomography (PET) tech. nology.

The HPRR is expected to resume operation with activities in several areas:

- training nuclear power plant health physics per. sonnel in neutron dosimetry. 
- conducting international dosimetry intercomparison studies.

- developing neutron dosimeters,

- testing criticality alarm monitors.

- supporting neutron radiobiology experiments, and

- testing physical systems (e.g., pumped lasers, neutron effects on materials, and shield effectiveness).

An outstanding feature of the division's research program is the broad interaction between divisional staff members and university professors, postdoctoral fellows, graduate students, and undergraduate students. University relations activities will continue to be a vital component of the division and wili be enhanced as opportunities arise in the future.

\section{Major Foreign Meetings}

To maintain and enhance international collaborations and to share research results, ORNL researchers will seek OHER approval to attend major society meetings and symposia held in foreign countries. We have also developed numerous foreign contacts as a result of the Chernobyl nuclear power station accident. These contacts have increased the foreign travel requirements. A list of majot foreign meetings scheduled for FY 1988 and FY 1989 is included in Table 10. It is anticipated that more than one ORNL researcher will seek approval to participate in these meetings. 


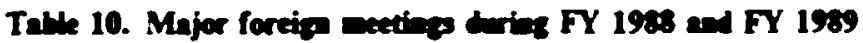

\begin{tabular}{|c|c|c|}
\hline Meeting & Location & Date \\
\hline $\begin{array}{l}\text { Worbshop on Methods for Assessing } \\
\text { the Reliability of Environmental } \\
\text { Transfer Models }\end{array}$ & Athens, Greece & Octcber 1987 \\
\hline $\begin{array}{l}\text { 2nd Wortshop on Radioiodinated } \\
\text { Free Fatty Acids }\end{array}$ & $\begin{array}{l}\text { Amsterdam, } \\
\text { The Netherlands }\end{array}$ & November 1987 \\
\hline $\begin{array}{l}\text { 4th International Symposium on the } \\
\text { Natural Radiation Environment }\end{array}$ & Lisbon, Portugal & December 1987 \\
\hline $\begin{array}{l}\text { 7th International Congrass of } \\
\text { the International Radiation } \\
\text { Protection Association }\end{array}$ & Sydney, Australia & April 1988 \\
\hline $\begin{array}{l}\text { Internstional Coaference on } \\
\text { Radiation Protection } \\
\text { Principles in Nuclear } \\
\text { Enersy }\end{array}$ & Syduey, Australia & April 1988 \\
\hline $\begin{array}{l}\text { 13th International Radiocarbon } \\
\text { Conference }\end{array}$ & Yogoslavia & June 1988 \\
\hline $\begin{array}{l}\text { NATO Wortshop on Biologically } \\
\text { Based Methods for Cancer } \\
\text { Risk Assessment }\end{array}$ & Corfu, Greece & Jupe 1988 \\
\hline $\begin{array}{l}\text { 7th International Symposium } \\
\text { on Radiopharmaceutioal } \\
\text { Chemistry }\end{array}$ & $\begin{array}{l}\text { Groningen, } \\
\text { The Netherlands }\end{array}$ & July 1988 \\
\hline $\begin{array}{l}\text { 4th International Congress } \\
\text { of Cell Biology }\end{array}$ & Montreal, Canada & Auguat 1988 \\
\hline $\begin{array}{l}\text { 4th Internstional Symposium } \\
\text { on Regulated Streams }\end{array}$ & Laughborough, UK & Auguar 1988 \\
\hline $\begin{array}{l}\text { XVI International Congress } \\
\text { of Genetics }\end{array}$ & Toronto, Canada & August 1988 \\
\hline $\begin{array}{l}\text { 9th International Conference on } \\
\text { Gas Discharges }\end{array}$ & Venice, Italy & September 1988 \\
\hline $\begin{array}{l}\text { I4tb L. H. Gray Conference on } \\
\text { Low-Dose Radiation- } \\
\text { Biological Basis of } \\
\text { Risk Ascessment }\end{array}$ & Oxford, UK & September 1988 \\
\hline 10tb Symposium on Mictodocimetry & Rome, Inaly & Summer 1989 \\
\hline $\begin{array}{l}\text { 24tb Congreas of the } \\
\text { International Aseociation } \\
\text { of Theoretical and } \\
\text { Applied Limnology }\end{array}$ & $\begin{array}{l}\text { Munich, Federal } \\
\text { Republic of } \\
\text { Germany }\end{array}$ & August 1989 \\
\hline
\end{tabular}




\section{Work for Non-OHER Organizations}

\section{Other DOE Organizations}

Approximately $58 \%$ of the funds for ORNL's BES Program is provided by organizations other than OHER (Fig. 1). DOE's Assistant Secretary for Environment. Safety, and Health (ASESH) provided about $11 \%$ of the BES funding in FY 1987 , which will increase to about 15\% in FY 1988.

Funding for life swiences research is also received from the Assistant Secretary for Nuclear Energy and the Assistant Sectetary for Conservation and Renewable Energy.

The importance of non-OHER-funded research has increased relative to DOE programs. For example, recently initiated studies on the Y-12 site related to how ecosystems respond to contaminants bave utilized techniques developed during the OHER Synthetic Fueis Program. This area will ircrease it importance over the next five years through applications at other DOE and federal sites.

Non-OHER support is particularly significant for work in the areas of geohydrology, geochemistry, and health risk assessment. The importance of these disciplines, along with environmental engineering, in proper waste management is recognized and sought both by waste research sponsors and waste operations groups. Integration of OHER research with applied waste studies provides contact with the basic research programs and ensures that the most current insights into environmental transporn processes are used in designing and operating waste facilities and remedial actions.

\section{Assistant Secretary for Environment, Safety, and Health}

The Environmen'al Sciences Division is continuing to provide technical support to ASESH's offices of
Nuclear Safety (ONS), Environmental Guidance and Compliance (OEGC), National Environmental Policy Act (NEPA) Project Assistance, and Environmental Audit. In support of ONS, division staff provide analyses and evaluations of proposed radiation protection orders. During the past year, a critical review of the chemical and radiological toxicity of uranium was prepared. In support of OEGC, division staff lead a multidisciplinary team that prepares analyses of regulatory initiatives related to bazardous waste management and other EPA programs. These analyses evaluate the technical approaches used in proposed rules and the implications of new requirements on DOE facilities and operations. The analyses and comments prepared by the ORNL team are used by OEGC in formulating DOE responses to EPA and other regulatory agencies on proposed requirements that might affect the deparment's activities. Technical support to the Office of NEPA Project Assistance consists of providing reviews and analyses of environmental impact statements and environmen. tal assessments prepared for DOE and preparing background materials for use by DOE staff in developing guidance on NEPA compliance issues. This support also provides technical assistance in evaluating environmental analyses related to DOE's high-level nuclear waste repository program.

ORNL is participating in the DOE Environmental Survey as one of three laboratories providing sam. pling and analysis support. This support is provided to the Office of Environmental Audit. In addition. ORNL is responsible for sample traffic routing among the survey laboratories and for providing assistance to DOE for management of data from the survey. The DOE Environmental Survey's aim is to evaluate potential environmental problems at 
approximately 40 DOE sites throughout the United States.

ORNL will continue to assist ASESH's Office of Environmental Analysis in developing environmental assessment methodologies and environmenial. economic, and energy data bases and in analyzing important energy and eavironmental issues such as air quality, acid deposition, and water resource impacts. Assistance is also provided in planning and preparedness for environmental protection and public safety, which includes assisting DOE in implementing its supporting responsibilities to other foderal, state, and local agencies in radiological emergencies. One problem being studied is the development of procedures, equipmeat, and techniques for decontamination and emergency operation in contaminated environments.

ORNL's cooperative work with foreign countries is exemplified by the technical advice and equipment the Laboratory provides to the Junta de Energia Nuclear in Spain for measuring radionuclides in people and in environmental samples such as food products, soil, and air. ORNL's assistance allows for ncreased counting capacity by alpha spectrometry of samples containing ${ }^{239} \mathrm{Pu}$ and by rapid, accurate, and inexpensive techniques of samples containing ${ }^{241} \mathrm{Am}$.

\section{Assirtant Secretary for Noclear Eserzy}

The largest component of this work is the Radiological Survey Activities (RASA) for the Uranium Mill Tailings Remedial Action Program

(UMTRAP). A RASA office has been opened in Grand Junction, Colorado, to assist in UMTRAP. The UMTRAP effort is primarily radiological surveys on private property near inactive mill tailings sites. Advancing state-of-the-art equipment and methodologies are an integral component of UMTRAP. The surveys will be completed by FY 1989.

\section{Assistant Secretary for Conservation and Renewable Energy}

The Environmental Ssiences Division is responsible for the terrestrial production activities for DOE's Biofuels and Municipal Waste Technology Division. The division manages the Short Rotation Woody Crops and Herbaceous Energy Crops programs and supports the necessary in-house research and analyses. The programs are focused on maxjmizing the productivity of terrestrial biomass to be utilized for energy while minimizing costs and environmental effects. Field research is conducted at university, industry, and other federal agency research sites. Economic. environmental, and regional analyses are conducted at ORNL to ensure proper growth and development of each of the program's components.

Environmental technical assistance is provided to the Division of Geothermal and Hydropower Development. A conticuing focts of current research is to providr. Guidance on the resolution of major environmesial constraints to hydropower development.

Health and safety research work involves ana!yzing laboratory and buman data in order to help focus research on the potential bealth effects $c$ ? highvoltage, $60-\mathrm{Hz}$ transmission lines. This area of rusearch is of potential interest to OHER.

Dielectrics research is being carried out for the Division of Electrical Energy Systems of the Office of Energy Storage and Distribution. Researchers are studying the physical properries of dielectric materials, the mechanisms of breakdown of such materials, and the development of superior dielectric materials. This work has been conducted over several years. Five international symposia on gaseous dielectrics have been organized and hosted, and the proceedings have been published. Studies of the toxicity and potential environmental effects of products formed during electrical breakdown of dielectric materials are also carried out. Research is also being conducted to delineate and understand the basic physical mechanisms of dielectric breakdown at an electrode/solid insulator interface. The work focuses on the efferts of microstructures, defects. impurities, and filament formation.

\section{Non-DOE Organizations}

Other federal agencies that provide funding through interagency agreements with DOE include the EPA. the Department of Health and Human Services (HHS), National Oceanic and Atmospheric Administration (NOAA), National Science Foundation (NSF), and the U.S. Army, Navy, and Air Force. Both DOE and non-DOE sponsors benefit from the work done for other agencies because the work is complementary, and all of it is performed in the same general locations in labora. tories where facilities. equipment, and staff are shared. 


\section{Air Force}

Basic studies are being carried out on the interactions of low-energy electrons with solids. Theoretical and experimental studies are being performed on photon emission from irradiated soiids. This work grew out of and is complemen. tary to the basic research in radiation physies that has been carried out in the physical and technolog. ical studies program in OHER over the past 30 years. Development and evaliation of the Defense Priority Model for ranking Department of Defense waste sites continues. Technical support is being provided for environmental assessments and impact statements.

\section{Army}

Efforts for the Army include studying the feasibility of using U.S. Army high-volume hazardous waste streams as supplementary feedstocks in industrial boilers, validating data for the Energy Conservation Investment Program, performing a development study for an Energy Conservation Technical Information and Analysis Center. developing surface-enhanced Raman scattering for chemical detection, performing theoretical and experimental research on photon emission from irradiated solids, and preparing environmental assessments for the demilitarization of chemical agents spread by the Army. Assistance with analysis of environmental matters for the Army Corps of Engineers and the Waterways Experiments Station continues. Possible health and environmental effects of munition wastes have been studied, and munition production wastc disposal methods are being assessed. Work is being done for the Army at the HPRR to address the transmissivity of infrared laser windows in nuclear radiation ervironments.

\section{Departoneat of Health and Human Services}

HHS supports research in carcinogenesis, genetics, and toxicology. HHS funding is expected to remain relatively constant over the next five years. The main branches of HHS that provide support are the National Cancer Institute (NCI); the National Heart, Lung, and Blood Institute (NHLBI); the National Insiitute of Environmental Health Sciences, including the National Toxicology Program (NTP); the National Institute of General Medical Sciences (NIGMS); the Food and Drug Adminis- tration (FDA); and the National Library of Medicine (NLM). Genetic, reproductive, and general toxicology data bases are being developed for the FDA, NLM, and NTP, which are avaiiable rationally as well as in other countries.

For NCI, ORNL is studying the mechanisms of viral-, chemical-, and UV-radiation-induced carcinogenesis; cocarcinogenesis of ionizing (X-1-ays or neutrons) and UV radiation; and DNA repair mechanisms in carcinozenesis. Two organ systems that have been widely studied are the respiratory tract and the skin. Both organs are important interfaces between the body and potentially hazardous agents in the environment. During the next five years, questions about the responses of ecological systems and how they relate to potential human health effects will be addressed.

For NHLBI and NCI, the Nuclear Medicine Program is developing a basic understanding of the chemistry and physiology of cerebrovascular and cardiovascular imaging agents. NIGMS has also sponsored ORNL and UT for a joint, multidisciplinary research project aimed at developing a new generation of fiberoptics-based fluoroimmunosensors to study biological and chemical systems of toxicological interest. This work, in conjunction with OHER-supported efforts, resulted in an I-R 100 award last year.

For the Agency for Toxic Substances and Disease Registry (ATSDR), the Office of Risk Analysis is providing guidance on the performance of health assessment at hazardous waste sites on the Superfund list. Methodologies to predict acute and chronic health effects resulting from exposures to hazardous chemicals are being developed.

\section{Electric Power Research Institute}

Research sponsored by the Electric Power Research Institute (EPRI) addresses critical national issues related to electric power generation. Major efforts in this area are directed at understanding the processes and mechanisms by which atmospheric deposition of energy-related pollutants affects ecosystems.

A major four-year project on the effects of acidic deposition on the nutrient status of forest ecosys. tems, the Integrated Forest Study Program. was initiated in CY 1985. ORNL is the lead organization, with coinvestigators from the State Lniversity 
of New York at Syracuse and at Albany, the University of Pennsylvania, the University of Washington, the National Park Service, and the Norwegian Forest Research Institute. This program involves mineral cycling studies at sites in New York, Washington, North Carolina, Tennessee, and Norway. Mechanistic laboratory and fieid research will be conducted at ORNL and the University of Georgia in support of this fieidoriented project.

Beginning in 1987, a major three-year study on the effects of wet and dry deposition on loblolly pine will be initiated as part of EPRI's research program, Responses of Plants to Interacting Stresses. The ORNL component, which is being conducted in collaboration with the Tennescee Valley Authority (TVA), complements similar research being initiated at universities. ORNL will examine the influence of ozone, soil magnesium level, and acidic precipitation, singly and in combination, on the growth of loblolly pine under field conditions. The focus of the research is the whole-plant physiological processes governing the response of seedlings to stress of natural and anthropogenic origin. The research will be conducted at the Air Pollution Effects Field Research Facility at NERP.

A multiyear project has recently been funded by EPRI to investigate compensation mechanisms and how they may affect important fish populations. This project builds on historic fish population modeling expertise developed in the early days of environmental assessment activities.

\section{Environmental Protection Agency}

ORNL's work for EPA addresses numerous heaith and environmental problems and issues. The research focuses on identifying the effects of pollutants associated with energy-production processes, effluents, and disposal, such as the effects of utility effluents on the environment. During the past year, studies have been initiated to relate the effects of contaminaat releases to ecological responses using ecosystem simulations. In addition, research also addresses the toxicity of leachates of solid wastes, human health hazards from incineration of hazardous chemicals, and the effects of acid precipitation on agricultural systems and forest soils. Analysis of the relationships between atmospheric deposition and surface water chemistry on a regional scale is leading to the development of multivariate statistical moudels io relate deposition watershed characteristics and lake chemistry. Continuing development and refinement of these methods will improve capability to extrapolate from site-specific data to predict the distribution and effects of atmospheric deposition across regions experieacing acidic depssition.

Acid precipitation activities co ntinue to include coordination and administration for assessment purpose, as well as an active participation in the Interagency Task Force on Acid Precipitation. ORNL manages and analyzes data coming from the National Surface Water Survey and the National Soils Survey, major EPA programs providing input to assessments of the acidic deposition problems. Data bases have been developed to examine the relationship between soils characteristics and the delayed-response lakes in the northeastern United States. ORNL has developed data that EPA will use in establishing a modified extraction procedure for designating wastes as hazardous. Continued development of these modified procedures, including toxicological evaluation, will provide the necessary information for establishing this modified standard.

Continuing projects in environmental risk analysis include a focus on methods development and evaluation in marine systems and evaluation of fish population and ecosystem models. Literature reviews and chemical hazard information profiles are prepared for EPA-selected topics and chemicals. Administrative management, coordination. and information support will continue to be provided to the EPA Gene-Tox Program to help evaluate mutagenicity bioassay systems. Interim guidance will be recommended to EPA on the use of genetic bioassays to screen samples of waste. water effluents.

EPA is supporting research at ORNL to evaluate the use of physiologically based pharmacokinetic models in the risk assessment process. The models allow for prediction of the relationships between applied dose and effective dose to target tissue. The chief advantage of physiologically based models is that, by simply changing the physiological parameters, the same model can be used to describe the dynamics of chemical transport and metabolism in mice, rats, and humans. These models are being used to investigate interspecies extrapolation and the extrapolation of dose between routes of administration. 
ORNL is also conducting risk-analysis and epidemiological studies for EPA. Field research on the relationship between cardiovascular disease and hard water and chlorination was completed.

Analysis of data from the full set of communities is under way.

A major collaborative research project to investigate radon entry and mitigation effectiveness is being sponsored by EPA, TVA, and DOE/OHER. This project is investigating seven bouses in New Jersey and eight houses in the Tennessee Valley area. Continuous monitoring of radon, temperature, and differential pressures is being conducted in basements and main floors of the homes. Detailed premitigation measurements are conducted prior to installation of mitigation, such osubslab ventilation. Several months of pre- and postmitigation monitoring is conducted in both warm anc cold weather to evaluate initigation effectiveness.

\section{Nary}

Basic studies are being conducted of the fundamental properties of gases and gas mixtures appropriate for use in diffuse discharge switches for assessment purposes. ORNL is also involved in studies of the properties of high-energy metastable negative ions and the laser-induced formation of molecular ions from excited atoms. Studies are also conducted on interaction of intense electron beams with condensed matter. This work complements and supports OHER studies of negative ion reactions relevant to energy deposition by ionizing radiation. ORNL provides technical support to the Navy on compliance with environmental regula. tions.

Sedimentation processes and heavy metals deposition in the vicinity of the inactive fleet at Pearl Harbor are being determined through dating and analysis of sediment cores.

\section{The National Science Foundation}

NSF continues to support basic ecosystem analysis research that complements OHER work at ORNL. Systems analysis of aquatic and terrestrial ecosystems in both theoretical and empirical studies are contributing to the understanding of forest growth dynamics, food chains, hierarchical organizations. and landscape ecology. A new research project focuses on the ecological processes and interactions that contribute to ecosystem resilience, the ability of an ecosystem to recover from disturbance. This research, which combines ecosystem simulation modeling and system-level experimentation, should provide a direct link between existing theory and empirical results. An improved understanding of ecosystem recovery processes derived from this basic research will benefit the ORNL studies of disturbed aquatic systems near the Oak Ridge facilities that are being conducted in concert with remedial action efforts. Studies addressing linked global element cycles as related to climate and each other emphasize carbon, nitrogen, and phosphorus. A new initiative with NSF is developing; it involves a collaborative effort between ORNL, the Great Smoky Mountains National Park, and UT to address the role of spatial and temporal beterogeneity in ecosystem resiliency.

NSF, in conjunction with DOE, continues to provide support for the National Center for Small Angle Scattering Research. This is a national user-dedicated facility that makes two main instruments available to users: the NSF-constructed, 30-m small-angle neutron-scattering instrument and the DOE-constructed, $10-m$ small-angle $X$ ray-scattering camera. These instruments are intended to provide state-of-the art capability for investigating structures of condensed matter on the scale of tens to hundreds of angstroms. They are used extensively for materials science research, as well as for research in biology, chemistry, polymer science, and diffraction physics. A theoretical program to study nonlinear interactions of intense electron beams in matter is under way.

NSF supports ORNL research to evaluate the scientific bases for assumptions used in the risk assessment process. The major assumptions arise from the necessity to extrapolate experimental results (1) across species from rats or mice to humans, (2) from the high-dose regions to which animals are exposed in the laboratory to the low. dose regions to which humans are exposed in the environment, and (3) across routes of administration. The work is intended for use by federal agencies responsible for regulating human exposure to chemical carcinogens.

\section{L'S. Nuclear Regulatory Commission}

At the request of the Nuclear Regulatory Commission (NRC), modifications were made to codes on 


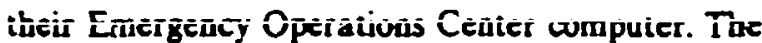
five-volume NRC Severe Reactor Accident Inciden Response Training Manual has been issued. The manual provides NRC personnel with information for guidance in responding to several reactor accidents.

\section{American Petrolean Institute}

American Petroleum Institute (API) supports research at ORNL to evaluate the pharmacokinetics and pharmacodynamics of benzene in humans. The work is intended to provide a better estimate of the risk of developing leukemia following exposure to low doses of benzene.

\section{US. Department of Apriculture}

The U.S. Department of Agriculture Forest Service/EPA Forest Research Cooperatives established to address acid rain issues identified by the National Acid Precipitation Assessment Program (NAPAP) have selected ORNL to (I) evaluate genotypic control of loblolly pine response to ozone and acid rain as part of the southern commercial forest research cooperative and to (2) develop a thorough understanding of the physiological mechanisms governing red spruce response to acid rain as part of the northern spruce research cooperative. In addition, ORNL is providing planning leadership for development of the eastern hardwood cooperative. The southern commerical cooperative, on behalf of all the cooperatives, recently selected ORNL to lead the effort on developing whole-tree exposure methodology and coordinating the efforts with other institutions.

\section{Other Support for Life Sciences Research}

Other agencies that support life sciences research include TVA, the National Aeronauties and Space Administration, the NOAA, the Consumer Product Safety Commission (CPSC), the National Research Council of Canada, the Air Force, the U.S. Park Service, the Federal Energy Regulatory Commission (FERC), and several universities.
Researca for the Pari Service íocuses on regionai analyses of environmental perturbations. ORNL is conducting research on the mechanisms of physiological response of forest tree seedlings to combined stresses of ozone and acid precipitation as a part of the Forest Service/EPA/NAPAP. sponsored Forest Response Program. Controlled exposure and field exposure methodologies developed at ORNL are beirg applied for both the Spruce-fir and Southern Commercial Pine Research Cooperatives of the program. ORNL provides input to environmental impact statements for hydroelectric projects for the FERC and is preparing assessments of multiple hydro development on river basins.

Work is being conducted for the Defense Nuclear Agency to provide better estimates of early radiation mortality and duty incapacitation from exposure to ionizing radiation

The collaborative interaction with Children's Hospital has provided access :o anatomical information that is being used in establishing an anatomical data base for children. This data base will be useful in the revision of the ICRP Reference Man report. Further developmeat of anatomical models for radiation transport calculations will also draw upon this data base.

The Defense Nuclear Agency-supported effort to measure residual ${ }^{\circ} \mathrm{Co}$ activation in Hiroshima steel is designed to address a major unresolved technical issue identified in the DS286 documentation developed under the DOE/OHER-supported Dosimetry for Human Exposure Program.

Two indoor air quality field studies were completed. Approximately $\mathbf{4 0 0}$ homes were monitored for a broad range of indoor air pollutants, including radon, formaldehyde, combustion gases, particulates, organics, and microorganisms. Multiagency support by EPA, CPSC. TVA. EPRI, and other private organizations allowed cost-effective use of limited resources to maximize tbe information obtained. 
This section highlights the major infrastructural barriers, significant issues, concerns, and prablems that could pose constraints on program development or the attainment of major goals and objectives.

\section{Personnel}

The ORNL Biomedical and Environmental Sciences (BES) Program has been restructured around a smaller number of major research clusters and activities, and we are continuing to build around initiatives in areas selected from Laboratory-wide and biomedical and environmental sciences planning activities. Several staff members have been added in key areas, such as Molecular Genetics, consistent with long-range plans and discussions with OHER personnel. The most recent addition to the staff, Dr. Richard Woychik, worked with Dr. P. Leder at Harvard University. A small number of individuals will be added through replacements and normal attrition. However, most of the ORNL staff additions will most likely come through the increased use of distinguished scientists, visiting scientists, and postdoctoral appointees. One Wigner Fellow, Dr. Laura B. Toran, is currently working in the Environmental Sciences Division (ESD) as a hydrologist. Wigner Fellowships are awarded by ORNL on a competitive basis to outstanding scientists who bave recently completed doctorates. An OHER-supported Hollaender Fellow, Dr. Monica Turner, is working in ESD as an ecologist. We have also hired several minority scientists in keeping with out Affirmative Action planning.

\section{Distinguished Scientists}

Dr. David White, the first Distinguished Scientist in the Biomedical and Environmental Sciences Pro- gram, joined ORNL early in 1986. Dr. White has been working with the Environmental Sciences, Biology, and Chemical Technology divisions and has attracted about 20 individuals to work at ORNL in activities telated to his interests. Dr. White is housed in offices and laboratories in the Environmental Sciences and Biology divisions. Among $D_{r}$. White's many interests is the use of biological organisms to alter hazardous wastes.

Dr. Rober Hatcher has been with the Environmental Sciences Division for about 18 months, working in the area of structural geology. Six individuals are now involved in these activities who were not previously associated with ORNL. Dr. David Joy, an elestron microscopist, joined ORNL's Metals and Ceramics Division in 1987. Dr. Joy will also work with ORNL scientists on the microscopy of biological systems.

Interviews and negotiations are ongoing with several other distinguisted scientist candidates. A joint working group has been established with UT at Knoxville to identify potential distinguished scientists in several areas of life sciences research. The distinguished scientist activities are part of the Science Alliance Program with UT at Knoxville. There are now II distinguished scientists at ORNL in the program.

Cost sharing or full suppor from OHER of these individuals is welcome.

\section{Capital Equipment}

The reliance on sophisticated equipment in the biological sciences places a high demand on capital equipment budgets. OHER is encouraged to make its case for an increased capital equipment budget. as recommended by its advisory committee (HERAC review of OHER 5-year plan. 1984) 
The budget level this year was $<5 \%$ of the operating budget, as opposed to the recommended level of 15\%. Modern biology requires a firm commitment to sophisticated instrumentation, and the 4.39 appropriated is grossly inadequate.

\section{Work for Others}

Work for others (WFO) is a major part of ORNL's integrated biomedical and life sciences program. As noted last year, we were pleased that OHER took the initiative to form a committee to investigate WFO activities and make recommenda. tions to OHER. However, the findings of this committee were ner st transmitted to the contractor laboratories.

Major programs of national prominence such as acid deposition are heavily dependent on funding from agencies other than DOE Major supporters include EPA, EPRI, and some of the other participants of the National Acid Precipitation Assessmeni Program (NAPAP), to which DOE belongs. NAPAP was established by law in 1980 and will terminate in a few years. We still feel the need for assistance from and joint planning with OHER to ensure that major activities in this important area do not disappear after the termination of NAPAP. This issue requires top OHER nanagement attention.

ORNL is continuing to work closely with the private sector in keeping with the goals and aspirations of DOE. Work for EPRI is an example of an important part of the integrated acid deposition program. Work in this area should be considered as a special category of WFO.

It has been suggested that OHER explore the possibility of developing arrangements (memoranda of understanding, blanket work orders, or basic ordering agreements) with organizations such as EPRI, the Gas Research Institute, and pertaps NSF. ORNL is particularly pleased that DOE is now forming joint working groups with individuals in NSF. The areas of interest identified were biotechnology, molecular biology, and the human genome. The purpose of these agreements would be to facilitate arrangements for conducting rese. . $c$ ch with these organizations. However, the plan for OHER to interact with NSF staff (Dr. Kingsbury) apparently has not been implemented.

\section{Construction}

A critical problem requiring immediate resolution has been the aging of the energy-inefficient facilities used by the Biology Division at the Y-12 site. In addition to the marginal service and utility capacities of the buildings, the cost of utilities was consuming almost $25 \%$ of the total research operating budget. This high cost of conducting research was adversely affecting ORNL's competitiveness in basic biological research and placed the future of this program in jeopardy. In FY 1987, the Biology Division staff began an interim program of reducing costs by eliminating fasilities and consolidating re :-arch activities. Biological research projects formerly located in the largest building (9207) were moved into two smaller buildings nearby. The long-range plan is to move the major research components of the Biology Division frem the $Y-12$ Plant to specially designed biological research facilities located in the Life Sciences complex at ORNL. It is quite clear that the only long-term solution is the construction of these new facilities. Leasing of facilities is not permitted.

Conceptual design has been completed for the proposed Molecular Genetics Laboratory as an FY 1990 line-item construction project (Table 11). The proposed laboratory will provide the resources required for advanced-level molecular genetics research. The building will be of cost-effective modular design, with one-time engineering and design costs, and additions will be modular units of the same design.

Because DOE/OHER's established genetics research program investigates the genetic effects of energy-related physical agents and chemicals. it is essential that ORNL have new laboratory and animal space designed specifically for handling hazardous chemicals safely, with an air supply system that can achieve the required high number of air exchanges per hour to meet the requirements for experimental animal quarters.

The obvious programmatic advantage to relocating the Biology Division in the existing Life Sciences complex at ORNL is that the close proximity to the Biomediral and Environmental Sciences divisions would provide an opportunity to share resources and thus enhance collaborative research effors. Many essential facilities for modern biological research (e.g. structural biology) are located 
Table 11. Proposed line-iten cosatraction projects

for Oak Ridge National Leboratory's Biomedical

an Enviromental Sciences Progens.

\begin{tabular}{cccc}
\hline Project & $\begin{array}{c}\text { Estimatod } \\
\text { Cost (SM) }\end{array}$ & FY & Comment \\
\hline $\begin{array}{c}\text { Upgrade air supply } \\
\text { system. Part I. } \\
\text { Bldg. 9210 }\end{array}$ & 2.8 & 1990 & $\begin{array}{l}\text { DOE approved CDR } 11 / 83 \\
\text { CDR updated 12/85 }\end{array}$ \\
$\begin{array}{c}\text { Molecular Genetics } \\
\text { Laboratory }\end{array}$ & 9.9 & 1990 & CDR completed 1/87 \\
$\begin{array}{c}\text { Upgrade air supply } \\
\text { system. Part II. } \\
\text { Bldg. 9210 }\end{array}$ & 3.8 & 1992 & $\begin{array}{l}\text { No approval to prepars } \\
\text { CDR }\end{array}$ \\
\hline
\end{tabular}

- Conceptual Design Report.

at ORNL. These facilities include the National Center for Small-Angle Scattering Research (NCSASR) and the Bioprocessing Research Facility.

\section{Operating Budget}

We strongly recommend more joint planning between OHER and its contractor laboratories. Several years ago, OHER developed plans for three-year budgets with the intent of making annual revisions to account for the realities of the federal budget. Unfortunately, these plans were never implemented. It is imperative that OHER work closely with its constituencies to fcimulate joint R\&D plans, including budgets.

\section{Health Physies Research Reactor}

The Health Physics Research Reactor (HPRR) is still shut down and, therefore, is not avallable for use by the Biology and Health and Safety Research divisions or other users. It is tmportant that the HPRR be made available for research in radiation biology and radiation dosimetry. We strongly encourage OHER to develop a plan to protect unique or rare radiation facilities at several of its contractor laboratories. 


\section{Resource Quantitation}

\section{Staff and Publications}

The total Biomedical a'd Environmental Sciences (BES) Program staff at ORNL approached 600 at the end of FY 1987. About half of the total professional staff holds $\mathrm{Ph}$.D.s, two individuais are M.D.s, two individuals are D.V.M.s, and the remainder have M.S. or B.S. degrees. In addition, many of the professional staff members hold university appointments.

ORNL's research programs provide opportunities for graduate as well as undergraduate students to work with researchers. The visiting scientists pro- gram is highly successful. Increasing emphasis is being placed on both the periodic and longer-term appointments of visiting scientists and students to offset the reduction in professional staff that occurred between 1981 and 1983. Table 12 shows the staff composition of the ORNL BES program.

The professional staff continues to maintain an excellent publication record using a variety of publication media: scientific journals, books and book chapters, and ORNL reports (Trimble et al. 1987). Table 13 provides numbers and types of publications for the OHER program.

Table 12. Oak Ridge National Laboratory Biomedical and Enviromenental Sciesces research staff (full-time equivileats)

\begin{tabular}{|c|c|c|c|c|c|c|}
\hline & \multicolumn{2}{|c|}{ FY 1986} & \multicolumn{2}{|c|}{ FY 1987} & \multicolumn{2}{|c|}{$\begin{array}{l}\text { FY } 1988 \\
\text { estimated }\end{array}$} \\
\hline & OHER & Total & OHER & Total & OHER & Total \\
\hline Professional (scientific) & 79 & 210 & $78^{\circ}$ & 202 & 77 & 248 \\
\hline Postdortorates & 16 & 26 & 20 & 37 & 20 & 40 \\
\hline Technicians & 50 & 168 & 54 & 194 & 51 & 134 \\
\hline Animal care & 35 & 43 & 32 & 41 & 29 & 37 \\
\hline Total direct personnel & 180 & 447 & 184 & 474 & 177 & 459 \\
\hline Professional (administrative) & 9 & 17 & 5.5 & 14 & 5.5 & 17 \\
\hline Clerical, administrative suppon & 33 & 90 & 30 & 92 & 31 & 127 \\
\hline Maintenance $^{b}$ & $s$ & 8 & 2 & 4 & 2 & 3 \\
\hline Total indirect personnel & 47 & 115 & 37.5 & 110 & 38.5 & 147 \\
\hline$V_{\text {isiting scientists }}^{c}$ & 34 & 83 & 36 & 57 & 36 & 69 \\
\hline Graduate students & 58 & 118 & 57 & 114 & 48 & 100 \\
\hline Undergraduates & 13 & 50 & 19 & 62 & 19 & 57 \\
\hline
\end{tabular}

'FY 1987: 71 Ph.D.. 2 M.D., 2 D.V.M., 33 M.S. 18 B.S.

"In laboratory overhead.

Tncludes both resident and periodic 
50 Biomedical and Environmental Sciences Program at ORNL

Talle 13. Office of Health and Enviromental Researchsported pubication

\begin{tabular}{lccc}
\hline & CY 1985 & CY 1986 & CY 1587 \\
\hline Journal articles & 166 & 185 & 121 \\
Proceedings & 12 & 38 & 12 \\
Books, chaprers & 35 & 16 & 9 \\
Reports & 40 & 29 & 25 \\
Meeting presentations & 303 & 358 & 369 \\
\hline
\end{tabular}

1987 figures may be incomplete.

\section{User Facility Statistics}

User facility statistics for the Bioprocessing

Research Facility, HPRR, and NERP are given in Table 14.

\section{Meetings Organized}

BES staff members Dr. C. W. Gehrs, Dr. P. J. Walsh, and Dr. W. M. Generoso are organizing an international symposium, "Bioindicators: Exposure and Effects," to be held March 20-23, 1988, in
Knorville, Tennescee. Organisms live in an esuironment containing a myriad of potentially harmful materials and integrate these into a realistic dose. This symposium is designed to identify various molecular, biochemical, and ecological indicators that enable quantification of dose and determination of risk to human and other organisms living in various environments. Biologists, ecologists, epidemiologists, medical researchers, and regulators from around the world will participate in the symposium. Five formal sessions are planned: (1) molecular epidemiology. (2) ecological indicators of human health, (3) biological indicators of environmental health, ( $($ ) biological mechanisms. and (5) forecasting buman and environmental health. For more information on the symposium, contact Dr. C. W. Gehrs, Oak Ridge National Laboratory, Environmental Sciences Division, P.O. Box X, Oak Ridge, Tennessee 37831.

Dr. R. H. Ritchie of the Health and Safety Research Division is organizing an international symposium, "i lth Werner Brandt Workshop on Penetration Phenomena," to be beld in Oak Ridge,

Table 14. User faclity date for FY 1987

\begin{tabular}{|c|c|c|c|}
\hline Uset affiliation & $\begin{array}{l}\text { Bioprocessing } \\
\text { Research Facility }\end{array}$ & $\begin{array}{l}\text { Health Physics } \\
\text { Research Reactor }\end{array}$ & $\begin{array}{l}\text { Oak Ridge National Environ- } \\
\text { mental Research Parke }\end{array}$ \\
\hline \multicolumn{4}{|l|}{ Participants } \\
\hline University & 3 & 7 & 43 \\
\hline Industry & 1 & 5 & 8 \\
\hline $\begin{array}{l}\text { U.S. Government } \\
\text { Laboratories }\end{array}$ & 0 & 0 & 7 \\
\hline DOE Laboratories & 0 & 14 & 0 \\
\hline ORNL & 1 & 8 & 51 \\
\hline Coreign & 4 & 0 & 6 \\
\hline Others & 0 & 0 & 15 \\
\hline Total & 9 & 34 & 130 \\
\hline \multicolumn{4}{|l|}{ User days } \\
\hline University & 105 & 14 & 1319 \\
\hline Industry & 90 & 8 & 767 \\
\hline U.S. Govemment & 0 & 0 & 185 \\
\hline DOE Laboratories & 0 & 28 & 0 \\
\hline ORNL & 30 & 57 & $22 ? 7$ \\
\hline Foreign & 115 & 0 & 94 \\
\hline Others & 0 & 0 & $\$ 23$ \\
\hline Total & 340 & 107 & 5165 \\
\hline
\end{tabular}

Data do not include 2022 school studenes ( 1011 user days) who participated in the Ecological Study Center's environmental rescarch activities. 
Tennessee, on April 14-15, 1988. This workshop will include various topics in penetration phenomena, with emphasis on inelastic effects in STM and STEM, vicinage and wake effects, convoy eiectrons, and track structure.

Drs. M. W. England and J. E. Turner of the Health and Safety Research Division, together with Dr. T. W. Schultz of The University of Tennessec, are organizing an international workshop "QSAR 88." This is the third international workshop on Quantitative Structure-Activity Relationships in Environmental Toxicology and will be held in Knoxville Tennessee, on May 22-26, 1988. Information on this workshop can be obtained from Dr. M. W. England, Oak Ridge National Laboratory, Health and Safety Research Division, P.O. Box X, Oak Ridge, Tennessee 37831-6123.

Drs. R. A. Popp, R. J. Preston, W. K. Yang, J. L. Epler, and E. M. Rinchik are organizing the Biology Division's Fortieth Anniversary research conference, "Transposable Elements in Mutagenesis and Regulation of Gene Expression." The conference, which is being dedicated to $D r$. Alexander Hollaender, will be held April 11-14, 1988, in Gatlinburg, Tennessee. The program is designed to present studies of specific genes and gene regulatory functions related to mutagenesis, gene expression, and neoplastic processes.

Meetings organized by ORNL BES staff during FY 1987 are listed below.

\section{Environmental Sciences Division \\ Interastional Confereace on Heary Metals in the Enviroament, New Orleans, Louisiana, Sep- tember 1987. Chairman: S. E. Lindberg.}

Short Rotation Woody Crops Program Annual Curtractors' Meeting, Oak Ridge, Tennessee, Augi'st 1987. Chairman: J. W. Ranney.

Herbaceous Energy Crops Program Anoual Subcontractors' Rerien, Oak Ridge, Tennessee, August 1987. Chairman: J. H. Cushman.

UEA 2ad Research Coordination Meeting on Mignation and Biological Transport of Rndioneclides from Stallow Land Burial, September 1987. Chairman: N. H. Cutshall.

Land Use and Carbon Dioxide Workshop, May 1987. Chairman: M. P. Farrell.

Ocean Carbon Cycle Workshop, May 1987. Chairman: M. P. Farrell.

Positive Feedback and Carbon Dioxide Worksbop, June 1987. Chairman: M. P. Farrell.

Global $\mathrm{CO}_{2}$ Modeling Workshop, July 1987. Chairman: M. P. Farrell.

Transport of Coatamimats in the Subsurface: Role of Organic and Inorganic Colloidal Particles, Manteo. North Carolina, October 1986. Chairman: J. F. McCathy.

\section{Health and Safety Research Dirision}

10th Werner Brandt Workshop on Penetration Phesomena, Alicante, Spai-, January 1987. Organizers: R. H. Ritchie and Alberto GrasMarti.

Carcioogen Risk Ascessment, Washington, D.C., April 1987. Organizer: C. C. Travis.

Fifth Intermational Symposium on Gaseous Dielectrics, Knoxviile, Tennessec, May 1987. Organizer. L. G. Christophorou.

The Liquid State and Its Electrical Properties, NATO ASI, Sintra, Portugal, July 1987. Codirector: L. G. Christophorou.

13th Personnel Dosimetry Intercomparison Study, Oak Ridge. Tennessee, July 1987. Organizer: C. S. Sims. 
D. E. Reichle, 1987. Environmental Sciences Division Annual Progress Report for Period Ending September 30, 1986. ORNL-6327, Oak Ridge National Laboratory, Oak Ridge, Tennessee, $190 \mathrm{pp}$.

Griesemer, R. A., 1987. Biology Division Progress Repori for the Period of October l. 1985-September 30, 1986, ORNL-6353, Oak Ridge National Laboratory. Oak Ridge. Tennessee, 212 pp.

Walsh, P. J., 1987. Health and Safety Research Division Progress Report for the Period October 1. 1985-March 31. 1987. ORNL-6389, Oak Ridge National Laboratory, Oak Ridge; Tennessee, 158 pp.

Postma, H., J. R. Merriman. F. R. Mynatt, C. R. Richmond, M. W. Rosenthal, D. B. Trauger, R. S. Wiltshire, A. Zucker, M. L. Sollen- berget, T. D. Anderson, J. R. Engel, L. L. Horton, C. A. Johnson, R. E. Pudelek, and J. E. Swift, 1987. Oak Ridge National Laboratory Institutional Plan FY 1988-FY 1993, ORNL/PPA-87/2, Oak Ridge National Labotatory, Oak Ridge. Tennessee, 169 pp.

Richmond, C. R., and J. L. Trimble, 1987. Biomedical and Environmental Sciences Programs at the Oak Ridge National Laboratory. Oak Ridge National Laboratory, Oak Ridge. Tennessec, $81 \mathrm{pp}$.

Trimble, J. L., G. R. Carter, W. C. Carter, J. R. Ellis, and V. S. Norman, 1987. Biomedical and Environmental Sciences Program Publications 1986. ORNL-6397, Oak Ridge National Laboratory, Oak Ridge. Tennessee. $65 \mathrm{pp}$. 


\section{Appendix A: Research Highlights}

The following ORNL research highlights for FY 1987 are included in this Appendix:

1. Colloidal material is important in contaminant transport in the subsurface environment;

2. Isotopic studies of sulfur dynamics in forest trees;

3. ${ }^{238} \mathrm{Pu}$, a tracer for river-ocean exchange processes;

4. Discovery of two new mechanisms of chemical mutagenesis;

5. Laser-based fiberoptics fuoroimmunosensor (FIS) for chemical and biological monitoring:

6. Crystal laser monitor,

7. Scanning-tunneling microscopy; and

8. Unlocking the structure-function secrets of $\mathrm{CO}_{2}$-fixation enzyme. 


\section{Coiloidal Material is Important in Contaminant Transport in the Subsurface Environment}

Research at ORNL sponsored by the Subsurface Transport Program has made significant progress in explaining the role of colloids in contaminant transport. The research focuses on the role of colloidal organic mactomolecules (COM) in enhancing the mobility of hydrophobic organic contaminants such as polynuclear aromatic hydrocarbons and polychloricated biphenyls. Laboratory studies have described the chemical and structural properties of COM that affect the binding of the contaminants to COM - with the goal of predicting the amount of contaminant that measures the transport of COM in aatural subsurface systems. Field studies measure the transport of COM in different subsurface environments to determine whether organic mactomolecules that bind the contaminants are mobile in groundwater and are potentially capable of cotransporting the contam. inants. This research will permit the role of COM in mobilizing organic contaminants to be incorporated in computer models and will significantly improve our capabilities to predict the transpon of energy-related wastes in groundwater.

Principal investigator: Dr. J. F. McCarthy

Environmental Sciences Division

Oak Ridge National Laboratory

615/576-6606 (FTS: 626-6606)

Caption for figure on the following page:

Natural organic matter in the colloidal size range can sorb environmental contaminants and enhance their transport in subsurface systems. However, organic colloids vary in their capacity for binding contaminants. The affinity of organic colloids from different surface and groundwaters for sorbing hydrophobic organic contaminants (such as polycyclic aromatic hydrocarbons) is directly related to the aromatic content of the colloidal material. The aromatic content is estimated spectrophotometrically from the absorption of $270 \mathrm{~nm}$. This easily measured parameter increases capabilities to predict the mobility of contaminants in subsurface quaifers. (ORNL.PHOTO (372-87) 


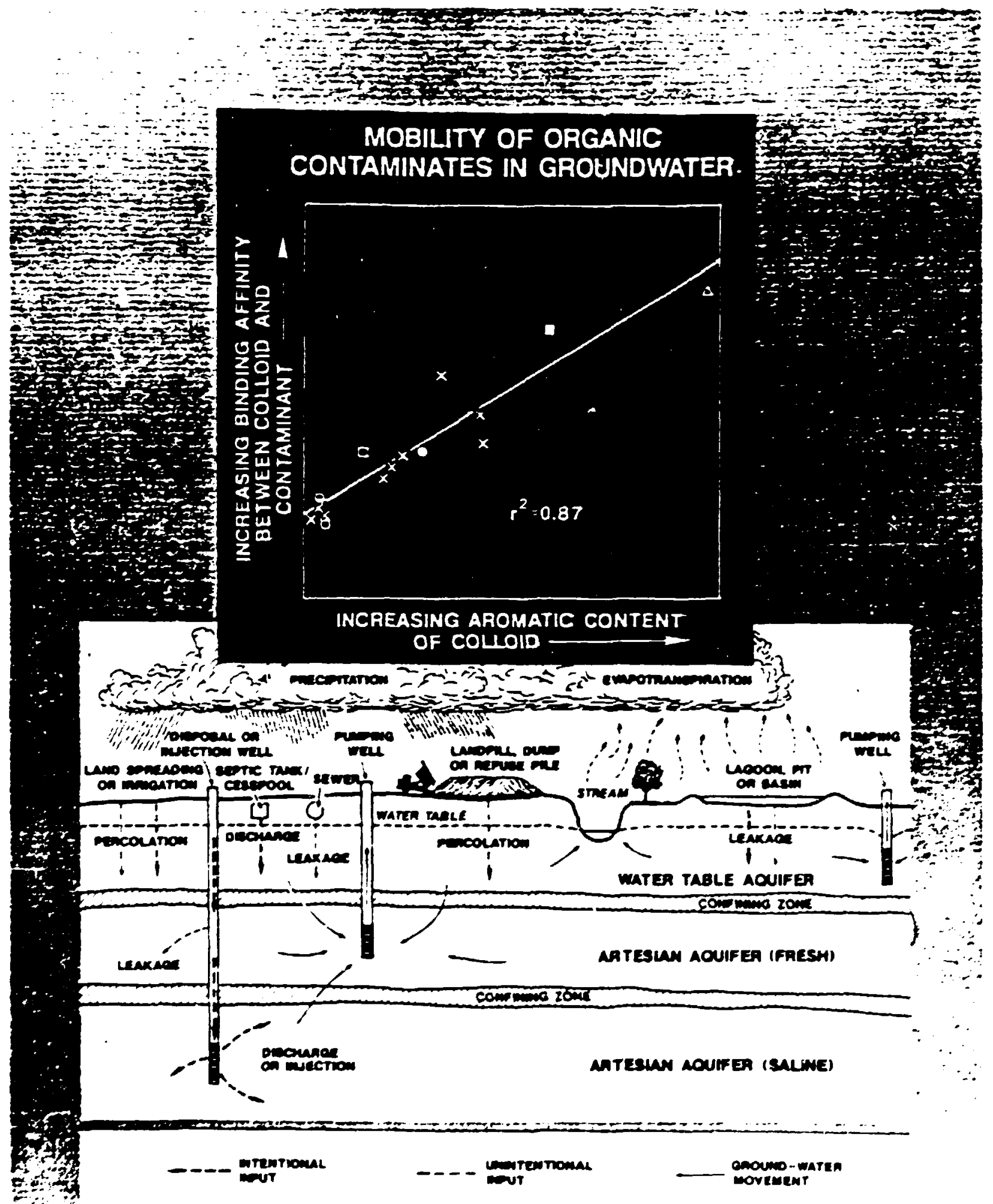




\section{Isotopic Studies of Sulfur Dynamics in Forest Trees}

The atmospheric deposition of sulfur (S) to Walker Branch watershed, near Oak Ridge, Tennessee, far exceeds the total annual $S$ requirement of the watershed forest. Geochemical factors are important in the watershed's retention of atmospheric inputs of $S$, but little is known about how forest trees cope with $S$ in excess of their nutritional demands. Sulfur-35 (a short-lived radioisotope) has been used in small amounts to reveal the cycling (e.g., leaf fall, translocation, and rainfall leaching), storage, and biogenic emission of $S$ by trees. These isotopic studies indicate little aboveground storage of $S$ in tree wood; instead. $S$ is translocated to roots, where some is lost to the soil through root death, and $S$ is recycled back to the atmosphere by means of foliar emissions of volatile $S$ compounds. Models of $\mathbf{S}$ cycling in forests do not normally account for these $\mathbf{S}$ dynamics in trees.

Although dry deposition (gases and particies) of $\mathbf{S}$ from the atmosphere is a major contributor of $\mathbf{S}$ to the watershed, dry-deposition measurements are difficult to obtain because of the complexity of the forest canopy. It was determined that leaching of $S$ from tree leaves by rainfall is a minor component of the $\mathbf{S}$ measured in throughfall (rainfall passing through the forest trees to the ground), and therefore, dry deposition is the major component of the $\mathbf{S}$ found in net throughfall (throughfall minus the contribution of incident rainfall). The significance of this finding is that during the growing season, when foliage is present, the amount of dry deposition to this forest can be estimated from sulfate in net throughfall. In addition to techniques using surrogate surfaces, throughfall measurement is a promising technique for estimating dry deposition of $S$ to other forests impacted by $S$ pollution because the tree canopy is the surface onto which deposition occurs.

Principal investigator: Mr. C. T. Garten, Jr.

Environmental Sciences Division

Oak Ridge National Laboratory

615/574-7355 (FTS: 624-7355)

Caption for figure on the following page:

Scientists sample foliage and stems in addition to litter and soil to determine ${ }^{35} S$ concentrations in these components. The data from the samples are used to determine the relative contributions of sulfur to the forest floor from atmospheric deposition and element recycling. (ORNL-PHOTO 4670-88) 
OANL-PHOTO 4670-88

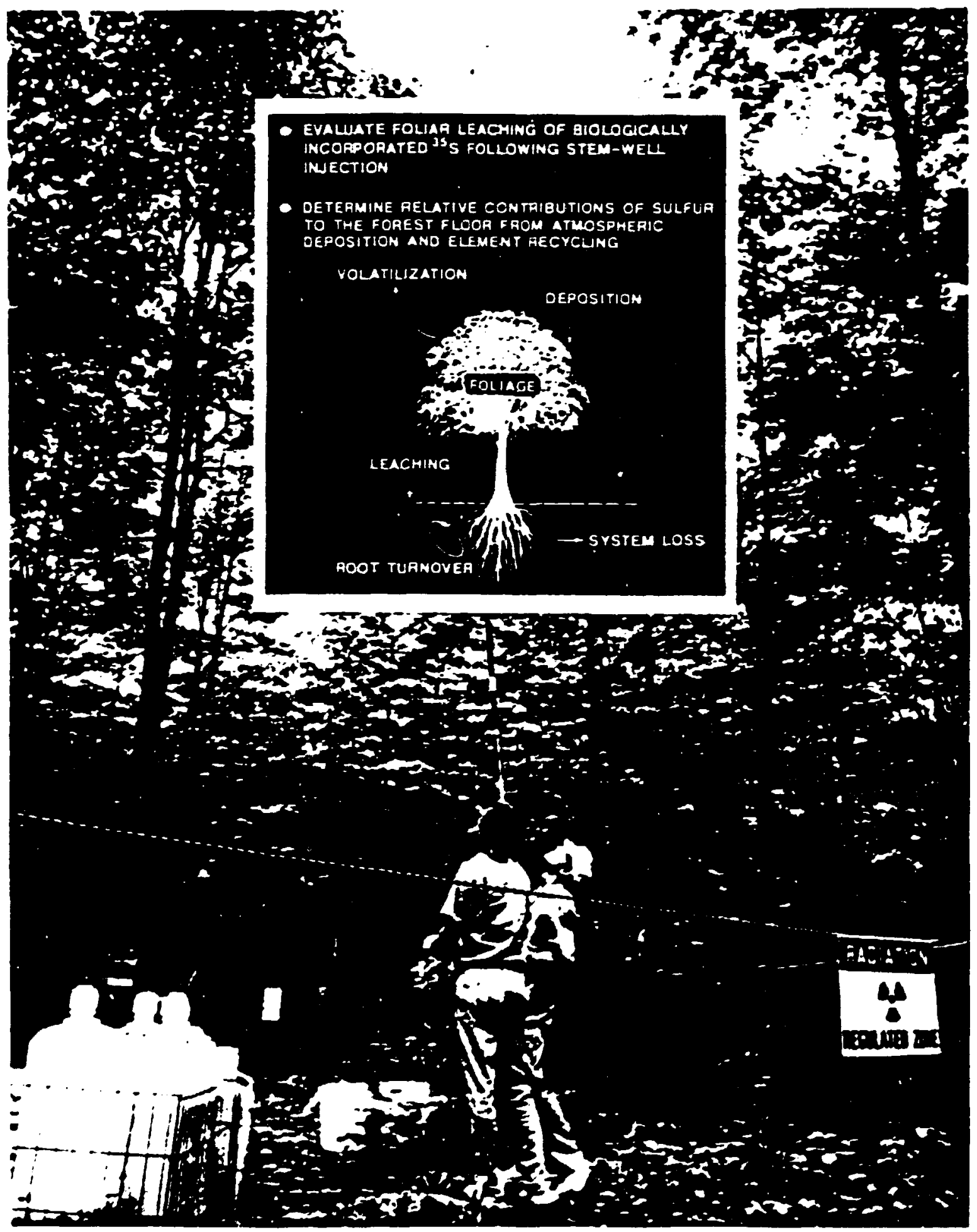




\section{${ }^{23 \hat{8}} \mathrm{Pu}$, a Tracer for River-Ocean Exchange Processes}

Plutonium-238 from the Savannah River Plant labels riverborne particles and provides a unique opportunity for tracing river-ocean exchange processes. Results indicate that inputs of plutonium from oceanic sources greatly exceed inputs from riverborne or drainage-basin sources as far upstream as $30 \mathrm{~km}$ in the Savannah River estuary, which is near the landward limit of seawater penetration. Because river-estuarine areas serve as effective traps for fine particles and associated substances, this landward transport from marine sources has important implications concerning the disposal of chemically reactive substances in oceanic waters off submergent coastlines. In addition, these results provide a rationale for the elevated plutonium and excess lead-210 concentrations and inventories that often occur in fine-grained estuarine and coastal sediments.

Principal investigator: Dr. C. R. Olsen

Environmental Sciences Division

Oak Ridge National Laboratory

615/576-0505 (FTS: 626-0505)

Caption for figure on the following page:

Large-volume water samples are collected for the extraction and measurement of naturally occurring and man-made radionuclides. The distribution of these radionuclides, including ${ }^{7} \mathrm{Be},{ }^{60} \mathrm{Co}{ }^{134} \mathrm{Cs}$, ${ }^{137} \mathrm{Cs}$, ${ }^{210} \mathrm{~Pb},{ }^{222} \mathrm{Rn},{ }^{226} \mathrm{Ra},{ }^{238} \mathrm{Pu}$, and ${ }^{239.240} \mathrm{Pu}$ are used to quantify transport and accumulation processes in rivers, reservoirs, estuaries, and coastal waters. (ORNL-PHOTO 0592-87) 


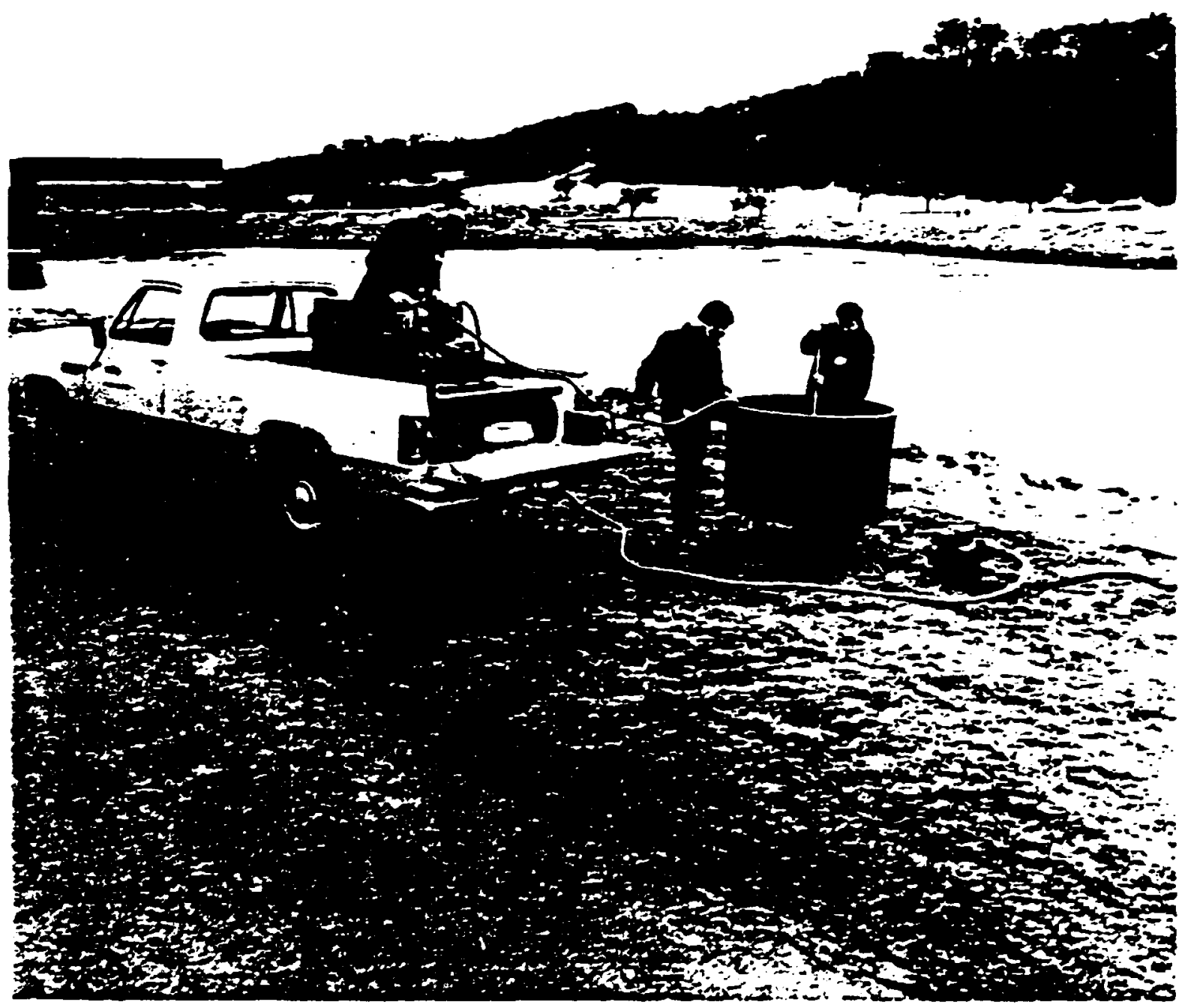




\section{Discovery of Two New Mechanisms of Chemical Mutagenesis}

DNA may not be the molecular target for certain induced genetic effects; and the outcome of chemical treatment at a certain germ-cell stage may be radically different from the types of outcomes reported earlier. These are the findings of two separate studies with ethylene oxide (EtO), but similar results have since been observed for certain other chemicals as well.

For years, the dogma has been that the target for chemically induced genetic effects is DNA. Biology Division investigators nuw show that in near-mature male reproductive cells of the mouse, the target may, in fact, be protamine, the predominant protein associated with the chromosomal DNA in these cells. The investigators measured alkylations in the sperm of mice that had been exposed by inhalation to very low levels of ${ }^{3} \mathrm{H}$-labeled EtO. The stage-related pattern of sperm protamine alkylation paralleled that for cerain heritable effects; by contrast, very little alkylation was found in the DNA.

When EtO is administered to mice shortly aftet sperm has entered the egg (early zygote stage), almost one-third of the resulting offspring die in the latter part of pregnancy-many of them being malformeo in a variety of ways. By contrast, all previous work with radiation administered to zygotes had shown an all-or-none effect, namely, very early embryonic death but normality of survivors. In the past, congenital anomalies following radiation or chemical exposure have been generated only by treatment during the period of major organogenesis (i.e., later in development) and have been stage specific, rather than highly varied, as now reported for EtO-exposed zygotes.

Principal investigators: Drs. W. M. Generoso and G. A. Sega

Biology Division

Oak Ridge National Laboratory

615/574-0861 (FTS: 624-0861)

615/574-0848 (FTS: 624-0848)

Caption for figure on the following page:

EtO alkylation in sperm heads recovered from the vasa deferentia of mice over a two-week period following inhalation exposure $(0-0)$. DNA was purified from remaining portions of the vas sperm samples except for the 14-d and 16-d time points where epididymal sperm DNA was used. The EtO binding in the sperm DNA over the two-week period was then determined as alkylation per deoxynucleotide $(\mathrm{dN})(\square-\square)$. All results were normalized to $1 \mathrm{ppm} / \mathrm{h}$ of EtO exposure. Er:or bars represent $\pm I S D$. 


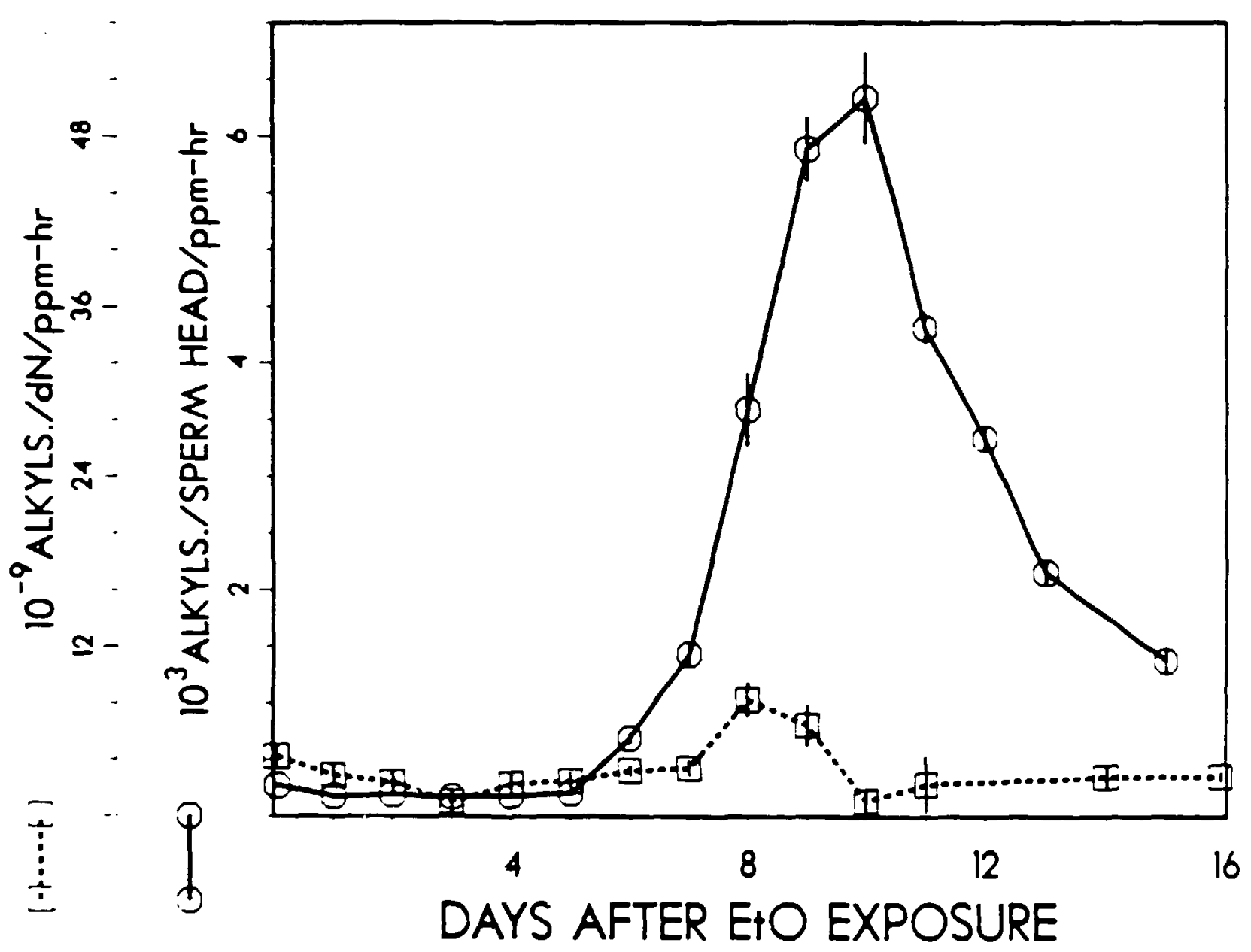




\section{Laser-Based Fiberoptics Fluoroimmunosensor (FIS) for Chemical and Biological Monitoring}

Recent developments in fluorescence instrumentation, biotechnology, and fiberoptics research have opened new possibilities for the development of sensitive and selective tools to measure human exposure to hazardous environmental chemicals and important biological compounds. Researchers in the Health and Safety Research Division have recently developed an instrument integrating fiberoptics, laser technology, antibody development, and immunofluorescence spectroscopy for use in the detection of trace amounts of carcinogenic compounds and their metabolites in complex samples.

The device is a unique fluorimmunosensor (FIS) that derives its analytical selectivity through the specificity of antibody-antigen reactions. Antibodies are immobilized at the terminus of a fiberoptical within the FIS, thus allowing both in vitro and in vivo fluorescence assays. High sensitivity is provided by laser excitation through a tiberoptic waveguide to the sensing and where antibodies are attached. Targeted antigens in biological samp's or in complex environmental mixtures attached to the antibodies are excited by the laser radiation, and then fluorescence is detected by a sensitive optical technique.

The FIS is a device with wide-ranging applications to chemical, biological, and environmental monitoring. Not only fluorescent but weakly fluorescent or nonfluorescent species can be monitored by fluorotagging methods. The feasibility of the FIS has recently been demonstrated by the detection of femtomole amounts of benzo(a)pyrene, a potent carcinogenic precursor frequently found in environmental and biological samples. Another positive feature of this FIS device is its ability to use minute amounts of sample (microliters), which should make it suitable for clinical analyses of human body fluids. The FIS was a recipient of an I-R 100 Award in 1987.

Principal investigator: Dr. T. Vo-Dinh

Health and Safety Research Division

Oak Ridge National Laboratory

615/624-6308

Caption for figure on the following page:

Researchers from Oak Ridge National Laboratory and The University of Tennessee are developing an antibody-based fluoroimmunosensor (FIS) for detecting femtomoles of carcinogens and related biological compounds in minute amounts of body fluids ( $\cdot \cdot R$ 100 Award winner in 1987). (Left to right: T. Vo-Dinh, M. J. Sepaniak, G. D. Griffin, K. R. Ambrose, and B. J. Tromberg.) (ORNLPHOTO 10100-87) 
ORNL-PHOTO 10100-87

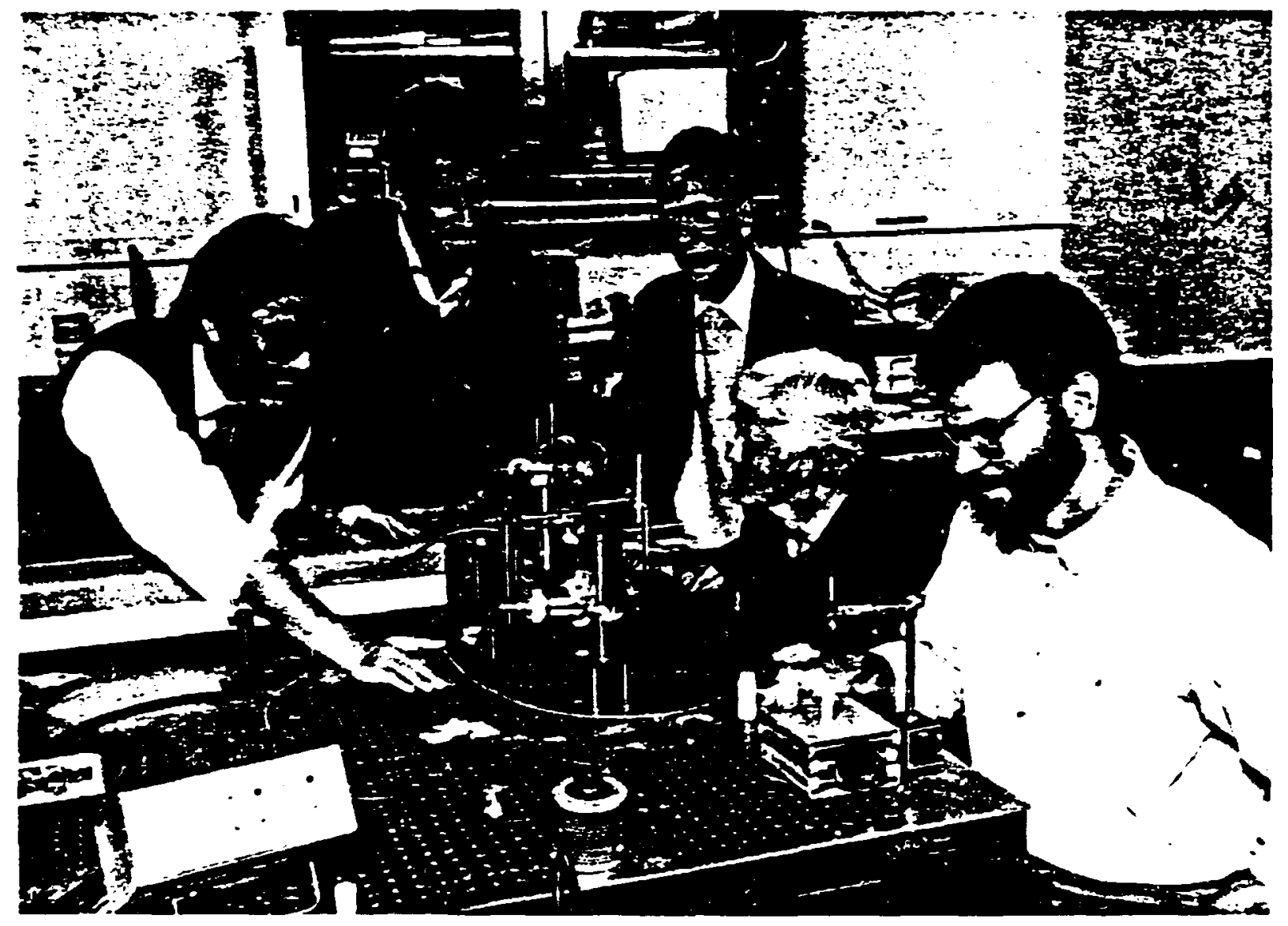




\section{Crystal Laser Monitor}

Ultraviolet lasers have found many important applications in science and industry. Because an ultraviolet laser beam is not visible to the human eye, the characteristies of the beam are not readily determined. But in most applications, it is important to know the size, shape, divergence, and the energy distribution of a laser beam. At ORNL, a simple and inexpensive uitraviolet laser beam monitor has been developed, for which an I·R 100 Award was granted in 1987. The monitor consists of an alkali balide crystal such as sodium chloride, potassium chloride, or cesium bromide doped with a material such as th.llium or excess alkali metal. When such a crystal is put in an ultraviolet laser beam, the resulting two-photon absorptions produce color centers in the transparent crystal. Thus, a three-dimensional color pattern develops in the crystal corresponding to the spatial and energy distribution of the ultraviolet laser beam to which the crystal was exposed. Once an ultraviolet laser beam has produced a colored intensity profile in the crystal, the crystal may be removed from the laser beam and viewed from all angles.

The three-dimensional profile of an ultraviolet laser beam will persist over long periods of time, or it can be erased to allow the monitor to be used again because heating or exposing the crystal to bright visible light removes all of the color centers. Thus, the monitor may be used and erased an indefinite number of times.

Principal investigator: Dr. C. H. Chen

Health and Safety Research Division

Oak Ridge National Laboratory

615/574-5895 (FTS: 624-5895)

Caption for figure on the foliowing page:

C. H. (Winston) Chen (center) holds a sample alkali halide crystal as he and other developers. Steven Kramer (left), and Michael McCann (right), stand behind a laser beam that is monitored by the rectangular crystal in the foreground. The Crystal Laser Monitor was a 1987 I•R 100 Award recipient. (ORNL-PHOTO 0786-85) 
OANL-PHOTO OO86-85

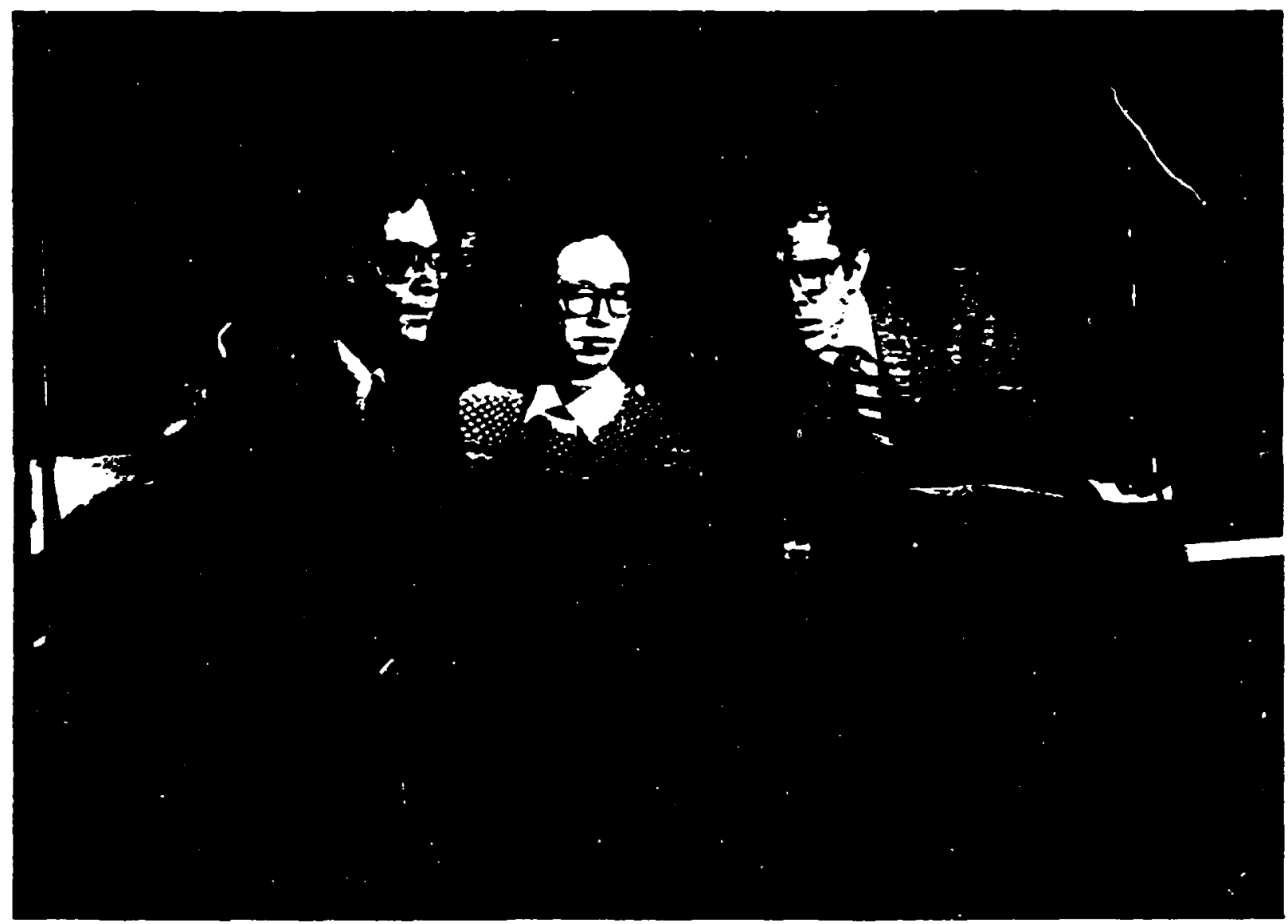




\section{Scanning-Tunneling Microscopy}

The recent invention of scanning-tunneling microscopy (STM) by the Nobel Laureates of 1986 , $G$. Binnig and $H$. Rohrer, permits resolution of the electronic distribution of individual atoms. The ORNL STM facility bas four electron STMs, three of which we constructed during the past two years. One of these operates in ultrahigh vacuum and has been used to obtain micrographs of atomic positions at the surfaces of several materials. It is currently being used to investigate the possibility of chemical identification of single clusters of nanometer size.

Three of our STMs operate in a fluid environment, which has enabled us to image arrays of carbon atoms. Biciagical applications are particularly well suited to these instruments, and we are currently obtaining contours of the tobacco-mosaic virus on gold substrates. We have also obtained mictographs that show the positions of long-chain hydrocarbon monomers on highly oriented pyrolytic graphite. Universities and other ORNL divisions have asked us to study a variety of samples in the STM facility, and much of the ensuing work bas been successful.

A unique photon STM invented in the ORNL Liquid and Submicron Physics Group may permit optical and ultraviolet imaging of a wide variety of samples that cannot be viewed by any other form of electron microscopy. It is expected that this instrument will exreed the resolution of ordinary optical microscopes by more than a factor of five in the sample plane and by a factor of fifty normal to the surface.

Principal investigator: Dr. T. L. Ferrell

Health and Safety Research Division

Oak Ridge National Laboratory

615/574-6214 (FTS: 624-6214)

Caption for figure on the following page:

Scanning-tunneling microscope image of tohacco-mosaic virus. The virus lies uncoated on a flat gold surface and was scanned in air. The dimensions of the virus are $250 \mathrm{~nm}$ long by $18 \mathrm{~nm}$ high. The protein cell siructure can be seen as ribs separated by only $2.4 \mathrm{~nm}$. This photograph represents ihe first complete STM image of a virus. (ORNL-PHOTO 0261-88) 


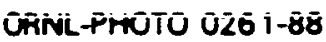

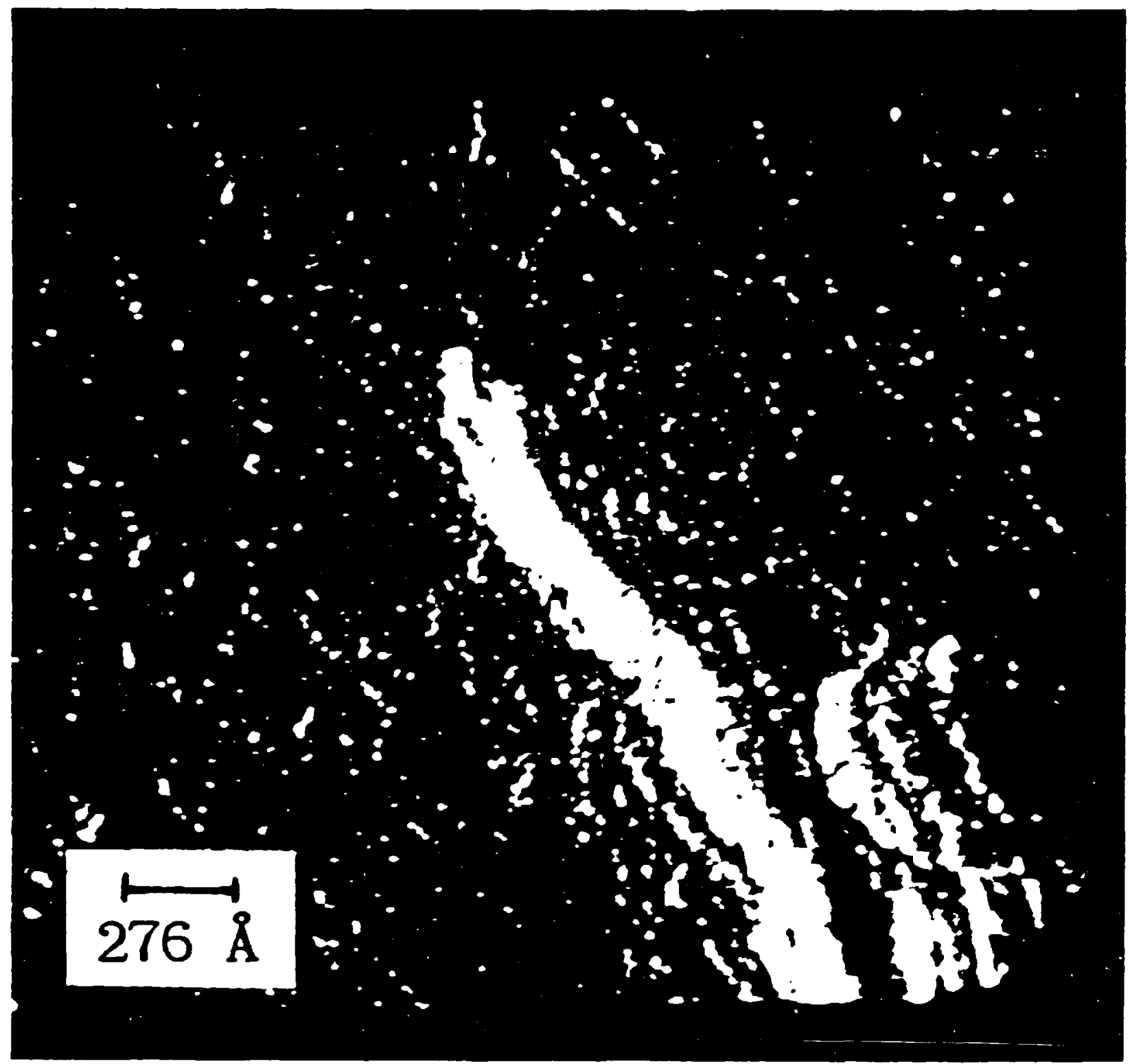




\section{Unlocking the Structure-Function Secrets of $\mathrm{CO}_{2}$-Fixation Enzyme}

Tne carbon di ide- $\left(\mathrm{CO}_{2}\right)$ fuxation enzyme is a cornerstone of life in that it enables photosynthetic organisms to cuuvert atmospheric $\mathrm{CO}_{2}$ into carbohydrates. Like many proteins, the $\mathrm{CO}_{2}$-fixation enzyme contains multiple, identical catalytic subunits (polypeptide chains). When the subunits of a protein are chemically and structurally identical, a fundamental question arises as to why biological activity is not exhibited by monomers but rather requires subunit-subunit association. One possibility is that catalytic sites are created by association of subunits. This postulate has been tested directly by protein engineering of the $\mathrm{CO}_{2}$-fixation enzyme.

Varied data have identified two amino acids that participate in catalysis and, hence, must be in spatial proximity. However, these two amino acids, glutamic acid at position $\mathbf{4 8}$ and lysine at position 166, are far apart on the linear polypeptide chain. Thus, their spatial proximity could be due to folding of individual subunits to generate an independent catalytic site within each subunit or could be due to interaction between subunits whereby position $\mathbf{4 8}$ on one subunit is adjacent to position 166 on another subunit. Catalytically inactive mutants result when other amino acids are placed at position 48 or 166 by protein engineering. However, when hydrids of these catalytically inactive mutants are formed by their coexpression from separate plasmids introduced into bacterial cells, enzyme activity is restor.d. Thus, the catalytic site must be created by subunit-subunit interaction, thereby explaining the absence of a monomeric form of this enzyme in nature. This finding is pertinent to ongoing structure/function correlation studies of the $\mathrm{CO}_{2}$-fixation enzyme, with the ultimate goal of designing a superior enzyme and hence a superior plant for enhanced yields of biomass.

Principal investigator: Dr. F. C. Hartman

Ṡology Division

Oak Ridge National Laboratory

615/574-0959 (FTS: 624-0959) 


\section{Appendix B: OHER-Supported Publications}

\section{OHER-Supported Publications for CY 1987}

A list of OHER-supported publications from ORNL's Biomedical and Environmental Sciences Program for FY 1987 follows. This list of 230 publications includes 164 refereed journal articles. 25 reports and/or documents, and 41 proceedings and/or book chapters. Because the list is compiled for the calendar year, the list may not be complete for 1986. The list is organized by ORNL division as follows: (1) Analytical Chemistry. (2) Biology, (3) Central Management Offices, (4) Chemical Technology, (5) Chemistry, (6) Computing and Telecommunications, (7) Energy, (8) Engineering Physics and Mathematics, (9) Environmental Sci.ences, and (10) Health and Safety Research. A complete list of ORNL's Biomedical and Environmental Sciences Program publications for CY 1986 was compiled in Trimble et al. 1987.

\section{Analytical Chemistry Division}

Buchanan, M. V., Rubin, I. B., Wise, M. B., and Glish, G. L., Formation of $M+14$ Anions from Fluorene: Negative Ion CI Studies U'sing GC/MS, MS/MS and FTMS," Biomed. Environ Mass Spectrom. 14, 395-99 (1987)

Buchanan, M. V. Rubia, I. B., Wise, M. B., and Glish, G. L., Formation of M + 14 Anions from Fluorene: Necative Ion CI Studies Using GC/MS, MS/MS and FTMS," Biomed. Environ. Mass Spectrom. 14. 395-99 (1987)
York, March 1986, Vol. 3, Am. Chem. Soc. 1986

Burton, D. E. Sepaniak, M. J., and Maskarinec, M. P., "The Effect of Injection Procedures on Efficiency in Micellar Electrokinetic Capillary Chromatography," Chromatographia 21, 583-86 (1986)

Griest, W. H., Tomkins, B. A., Reagan, R. R., and Russell, J. W., "Comparison of Selected Four- to Six-Ring Polycyclic Aromatic Hydrocarbon Dermal Tumorigens in Coal-Derived Liquids and Solids," Fuel 66, 408-11 (1987)

Ma, C. Y., Ho, C. -H., Caton, J. E., Griest, W. H., and Guerin, M. R., "Isolation and Identification of Benzoquinolines in Natural and Synthetic Crude Oils," Fuel 66, 612-17 (1987)

Sepaniak, M. J., Burton, D. E., and Maskarinec, M. P., "Micellar Electrokinetic Capillary Chromatograpy," pp. 142-51 in Ordered Media in Chemical Separations, Proceedings of the 191st Meeting of the American Chem:cal Society. New York, April 13-18, 1986. Am. Chem. Soc. Symp. Ser. 342, 1987

Wise, M. B., “Ultra-High-Resolution Dauginter Ion Tandem Mass Spectra Using a 
B-2 Biomedical and Environmental Sciences Program at ORNL

Differentially Pumped Dual Cell Fourier

Transform Mass Spectrometer," Anal. Chem.

59, 2289-93 (1987)

Wise M. B., Buchanan, M. V., Parks, S. K, and Hass, J. W, III, "Multimode Ionization Cell for Gas Chromatographic Detection," Rev. Sci. Instrum. 57, 3075-80 (1986)

\section{Biology Division}

Allison, D. P., Daw, C. S., and Rorvik, M. C., -Th: Construction and Operation of a Simple Inexpensive Slam Freezing Device for Electron Microscopy," J. Microsc. 147, 103-8 (1987)

Arnaise, S, Boeuf, H., Buisson, J. P, Cantat, N, Demerseman, P, Einhorn, J., Lamotte, G., Lemelin, M., Brimer, P. A., Perdue, S. W., Hsie, A. W, Royer, R, Kelly, F, and Hofung, M., “Mutagenicity Testing. Genotoxic Activities of 2-Nitronaphthofurans and Related Molecules," Mutagenesis 1, 217-29 (1986)

Asbley, T., and Russell, L B., "A New Type of Nonhomologous Synapsis in $T(X ; 4) ! R$ ! Translocation Male Mice," Cytogenet. Cell Genet. 43, 194-200 (1986)

Avner, P., Amaud, D., Amar, L., Cambrou, J., Winking, H., and Russell, L. B., "Characterization of a Panel of Somatic Cell Hybrids for the Regional Mapping of the Mouse X Chromosome," Proc. Nall. Acad. Sci. USA 84. 5330-34 (1987)

Bielanski, A., Schneider, U., Pawlyshyn, V., and Mapletoft, R. J., “Factors Affecting Survival of Deep Frozen Bovine Embryos In Vitro: The Effect of Freezing Container and Method of Removing Cryoprotectant," Theriogenology 25, 429-37 (1986)
Boulden, A. M., Foote, R. S, Fleming, G. S., and Mitra, S., "Purification and Some Properties of Human DNA- $0^{6}$-Methylguanine Methyltransferase," J. Biosci. 11, 215-24 (1987)

Cadilla, C. L, Robersor, A. E, Harp, J. M. Olins, A. L, and Olins, D. E., “Subfractionation of Soluble Macronuclear Chromatin and Enrichment of Specific Genes as Chromatin from Euplotes eurystomus," Nucleic Acids Res. 14, 8501-12 (1986)

Cook, J. S., "Spark" vs "Soup:z(cq A Scoop for "Soup," News Physiol. Sci. 1, 206-8 (1936)

Cook, J. S., Shaffer, C., and Cragoe, E. J., Jr., "Inhibition by Amiloride Analogues of $\mathrm{Na}^{+}$-Dependent Hexose Uptake in LLC-PK $1 / \mathrm{Cl}_{4}$ Cells," Am. J. Physiol. 253 (Cell Physiol. 22), C199-C204 (1987)

Dawson, W. D., and Cook, J. S., "Parallel Changes in Amino Acid Transport and Protein Kinase C Localization in LLC.PK 1 Cells Treated with TPA or Diradylglycerols," $J$. Cell. Physiol. 132, 104-10 (1987)

Flanagan, J. M., and Jacobson, K. B., -Effect of Zinc Ions on tRNA Structures: 1.

Reversed-Phase Chromatography," J.

Chromatogr. 387, 139-54 (1987)

Fry, R. J. M., "Neutron Effects in Humans: Protection Considerations," presented at Int. Neutron Therapy Workshop on Brachy vs Beam Therapy, Lexington, Ky., April 21-24, 1985, Nucl. Sci. Appl. 2, 397-407 (1986)

Fry, R. J. M., "Radiation Effects in Space," Adv. Space Res. 6, 261-68 (1986)

Fr;, R. J. M., and Fry, S. A., "Ionizing Radiation: Late Somatic Effects in Humans," pp. 
2422-23 in Encyclopedia of Materials Science and Engineering. Pergamon, Oxford, 1986

Fry, R. J. M., Storer, J. B., and Burns, F. J., "Radiation Induction of Cancer of the Skin," presented at Workshop on Radiation Damage to Skin: Fundamental and Practical Aspects, Paris, Oct. 9-11, 1985, Br. J. Radiol. 59 (Suppl. 19), 58-60 (1986)

Goad, M. E. P., Tryke, A. Fo and Witschi, H. P., “Acute Respiratory Failure Induced by Bleomycin and Hyperoxia: Pulmonary Edema, Cell Kinetics, and Morphology," Toxicol. Appl. Pharmacol. 90, 10-22 (1987)

Goad, M. E. P., Tryka, A. F, and Witschi, H. P., "Surfactant Alterations Following Acute Bleomycin and Hyperijaia-Induced Lung Damage," Toxicol. Le!!. 82, 173-78 (1986)

Hanson, W. R., Fry, R. J. M., Sallese, A. R., Frischer, H., Ahmad, T., and Ainsworth, E. J., -Comparison of Intestine and Bone Marrow Radiosensitivity of the $B A L B / C$ and the C57BL/6 Mouse Strains and Their B6CF $_{1}$ Offspring," Radiat. Res. 110, 340-52 (1987)

Hartman, F. C., Larimer, F. W., Mural, R. J.

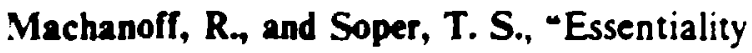
of Glu-48 of Ribulose Bisphosphate Carboxylase/Oxygenase as Demonstrated by Site-Directed Mutagenesis," Biochem. Biophys. Res. Commun. 145, 1158-63 (1987)

Hartman, F. C., Soper, T. S., Niyogi, S. K., Mural, R. J., Foote, R. S., Mitra, S., Lee, E. H., Machanoff, R., and Larimer, F. W., -Function of Lys-166 of R. rubrum Ribulosebisphosphate Carboxylase/Oxygenase as Examined by Site-Directed Mutagenesis," $J$. Biol. Chem. 262, 3496-501 (1987)
Hellwig, R. J., and Niyogi, S. K., "A Review of Protein Factors and Nucleoprotein Complexes Involved in Specific Transcription by Eukaryotic RNA Polymerase II," pp. 107-10 in Chemistry and Biology of Pteridines. Proceedings of the 8th International Symposium on Pteridines and Folic Acid Derivatives, Montreal, Canada, June 14-2l, 1986. Walter De Gruyter and Co., Berlin and New York, 1986

Helman, R. G., Hall, J. W., and Kao, J. Y., "Acute Dermal Toxicity: In Vivo and In Vitro Comparisons in Mice," Fundam. Appl. Toxicol. 7, 94-100 (1986)

Jacobson, K. B., "Post-Translational Regulation of Two Enzymes, Tryptophan Oxygenase and Sepiapterin Synthase, in Drosophila," presented at Symposium, pp. 3-13 in Recent Progress of Molecular Biology and Genetic Engineering of Korea, Proceedings of the Ist Conference on Molecular Biology \& Genetic Engineering, Seoul, October 16-17, 1986 . Institution for Molecular Biology \& Genetics, Seoul National University, Korea, 1986

Jacobson, K. B., and Ferre, J., "Use of C18 Silica Cartridges to Purify and Characterize Pterins," pp. 107-10 in Chemistry and Biology of Pteridines, Proceedings of the $8 \mathrm{th}$ International Symposium on Pteridines and Folic Acid Derivatives, Montreal, Canada, June 14-21, 1986, Walter de Gruyter and Co., Berlin and New York, 1986

Jamisoly C. Son and Adler, H. l., "Mutations in Escherichia coli That Effect Sensitivity to Oxyzen," J. Bacteriol. 169, 5087-94 (1987)

Kao, J., and Hall, J., "Skin Absorption and Cutaneous First Pass Metabolism of Topical Steroids: In Vitro Studies with Mouse Skin in 
Organ Culture," J. Pharmacol. Exp. Ther. 241, 482-87 (1987)

Kennel, S. Jo, Hotchkiss, J. A, Rorvik, M. C, Allison, D. P. and Foote, L. J., “Rat Monoclonal Antibodies to Mouse Lung Components for Analysis of Fibrosis," Exp. Mol. Pathol. 47, 110-24 (1987)

Kuemmerle, N. B, Cr'ang, L. -Y, Koh, C. K. Boone, L. R., and Yang, W. K., “Characterization of Two Solitary Long Terminal Repeats of Murine Leukemia Virus Type That Are Conserved in the Chromosome of Laboratory Inbred Mouse Strains," Virology 160, 379-88 ( 1987)

Last, J. A., Warrea, D. Lo, Pecquet-Goad, E, and Witschi, H. P., "Modification by Ozone of Lung Tumor Development in Mice," J. Natl. Cancer Inst. 78, 149-54 (1987)

Lee, E. H. Soper, T. S., Mural, R. J. Stringer, C. D., and Hartman, F. C., “An Intersubunit Interaction at the Active Site of D-Ribulose-1,5-bisphosphate Carboxylase/Oxygenase as Revealed by Cross-Linking and Site-Directed Mutagenesis," Biochemistry 26, 4599-604 (1987)

Lee, E. H. Stringer, C. D., and Hartman, F. C., "Distance Between Two Active-Site Lysines of Ribulose Bisphosphate Carboxylase from Rhodospirillum rubrum," Proc. Natl. Acad. Sci. 83, 9383-87 (1986)

Ley, R. D., Applegate, L. A, Stuart, T. D, and Fry, R. J. M., "UV Radiation-Induced Sk . Tumors in Monodelphis domestica," Pnotodermatology 4, 144-47 (1987)

Lindenschmidt, R. C., Tryka, A. F., and Witschi, H. P., "Modification of Gastrointestinal
Tumor Development in Rats by Dietary Butylated Hydroxytoluene," Fundam. Appl. Toxicol. 8, 474-81 (1987)

Mann, R. C., "On Multiparameter Data Analysis in Flow Cytometry," Cytometry 8, 184-89 (1987)

Mann, R. C., Mansfield, B. K, and Selkirk, J. K., "Methods for Computer Analysis and Comparison of Two-Dimensional Protein Patterns Obtained by Electrophoresis," presented at NATO Advanced Study Institute on Pattern Recognition, Spa, Belgium, June 9-20, 1986, pp. 529-37 in Pattern Recognition Theory and Applications, Springer-Verlag, Berlin, 1987

Merrick, B. A, and Selkirk, J. K., "Separation of Glucuronide, Sulfate and Glutathione Conjugates of Benzo( a)pyrene by HPLC," pp. 561-77 in Polynuclear Aromatic Hydrocarbons, Proceedings of the 9th International Symposium on Chemistry, Characterization and Carcinogenesis, Columbus, Ohio, October 30-November 1, 1984, Battelle Press, Columbus, Ohio, 1986

Miller, A. B., Bruce, W. R., Fry, R. J. M., and Hoffman, D., "Symposium: Carcinogenesis," presented at Symp. on Carcinogenesis, Toronto, Sept. 22, 1986, Annales of the Royal College of Physicians and Surgeons of Canada, 20, 262-64 (1987)

Niyogi, S. K., Soper, T. S., Foote, R. S., Larimer, F. W, MuraL, R. J., Mitra, S., Lee, E. H., Machanoff, R., and Hartman, F. C., - Site-Directed Mutagenesis to Determine Essential Residues of Ribulose-Bisphosphate Carboxylase of Rhodospirillum rubrum," $J$. Biosci. 11, 203-14 (1987)

Oakberg, E. F., Gosslee, D. G., Huckins, C., and Cummings, C. C., "Do Spermatogonia! 
Stem Ceiis Have a Circadian Khythm?" Ceii and Tissue Kinet. 19, 367-75 (1986)

Popp, R. A., D'Surney, S. J., and Wamrzynixk, C. J., -Changes in Expression of Murine Alpha- and Beta-Globin Genes During Development," presented at 5th Hemoglobin Switching Conf., Warrenton, Va., Sept. 30-Oct. 1, 1986, pp. 81-89 in Progress in Clinical and Biological Research. Developmental Control of Globin Gene Expression. Vol. 251, Alan R. Liss, Inc., New York, 1987

Preston, R. J., Dean, B. J., Galloway, S., Holden, H., McFee, A. F., and Shelby, M., -Mammalian In Vivo Cytogenetic Assays. Analysis of Chromosome Aberrations in Bone Martow Cells," Mutat. Res. 189, 157-65 (1987)

Preston, R. J., San Sebastian, J. R., and McFee, A. F., "The In Vitro Human Lymphocyte Assay for Assessing the Clastogenicity of Chemical Agents," Mutat. Res. 189, 175-83 (1987)

Rothrock, R., Lee, K. -L., Isham, K. R., Johnson, A. C., and Kenney, F. T., “Different Mechanisms $C$ ontrol Developmental Activation of Transcription of Genes Subject to Identical Hormonal Regulation in Adult Liver," Biochem. Biophys. Res. Commun. 144, 1182-87 (1987)

Roy, D., and Mitra, S., "Preliminary Studies on Molecular Characterization of the Two New Pseudomonas Species Capable of Utilizing Chloroaromatic Compounds," presented at Symposium, pp. 275-81 in Proceedings of the 8th Symposium on Biotechnology for Fuels and Chemicals, Garlinburg, Tennessee, May 13-16, 1986. Biotechnology and Bioengineering Symposium 17. John Wiley, 1987
Kusseiī, i. $\bar{B}_{n}$ and Hunsicker, $\bar{P} . \bar{K}$., -Study of the Base Analog 6-Mercaptopurine in the Mouse Specific-Locus Test," Mutat. Res. 176, 47-52 (1987)

Russell, W. L., "Ionizing Radiation: Genetic Effects in Humans," pp. 2421-22 in Encyclopedia of Materials Science and Engineering, Pergamon, 1986

Schneider, $U_{\text {, }}$ and Mazur, P., -Relative Influence of Unfrozen Fraction and Salt Concentration on the Survival of Slowly Frozen Eight-Cell Mouse Embryos, " Cryobiology 24. $17-41$ (1987)

Sega, G. A., and Owens, J. G., "Binding of Ethylene Oxide in Spermiogenic Germ Cell Stages of the Mouse After Low-Level Inhalation Exposure," Environ. Mol. Mutagen. 10, 119-27 (1987)

Sendelbach, L. E., and Witschi. $\dot{H}$. P., “Bronchoalveolar Lavage in Rats and Mice Following Beryllium Sulfate Inhalation," Toxicol. Appl. Pharmacol. 90, 322-29 (1987)

Sendelbach, L. E., and Witschi, H. P., “Protection by Parenteral Iron Administration Against the Inhalation Toxicity of Beryllium Sulfate," Toxicol. Lett. 35, 321-25 (1987)

Siracusa, L. D., Russell, L. B., Eicher, E. M., Corrow, D., Copeland, N. G., and Jenkins, Y. A., "Genetic Organization of the Agouti Region of the Mouse," Genetics 117, 93-100 (1987)

Siracusa, L. D., Russell, L. B., Jenkins, N. A., and Copeland, N. G., "Allelic Variation Within the EMV-15 Locus Defines Cellular Sequences Closely Linked to the Agouti Locus on Mouse Chromosome 2." Genetics $117,85-92$ (1987) 
Snow, E T, and Mirte, S., "Do Carcinogea: Modified Deoxynucleotide Procursors Contribute to Cellular Mutagenesis?" Cancer Invest. 5. 119-25 (1987)

Stankorski, L F, Jr., Tindall, K. R, and Hsie, A. W., "Quantitative and Molecular Analyses of Ethyl Methanesulfonate- and ICR-191-Induced Mutation in AS52 Cells," Mutat. Res. 160, 133-47 (1986)

Stevens, A., and Maupin, M. K., “A 5' $\geqslant 3$ ' Exoribonuclease of Saccharomyces cerevisiae: Size and Novel Substrate Specificity, "Arch. Biochem. Biophys. 252, 339-347 (1987)

Stevens, A., and Maupin, M. K., "A S' $\geqslant 3$ ' Exoribonuclease of Human Placental Nuclei: Purification and Substrate Specificity," Nucleic Acids Res. 15, 695-708 (1987)

Thiessen, K. M., and Lalley, P. A., “New Gene Assignments and Syntenic Groups in the Baboon (Papio papio)," Cytogenet. Cell Genet. 42, 19-23 (1986)

Thiessen, K. M., and Lalley, P. A., “Gene Assignments and Syntenic Groups in the Sacred Baboon (Papio hamadryas)," Cytogenet. Cell Genet. 44, 82-88 (1987)

Ullrich, R. L., Jernigan, M. C., Satterfield, L. C., and Bowles, N. D., "Radiation Carcinogenesis: Time-Dose Relationships, "Radiat. Res. 111, 179-84 (1987)

Ullrich, R. L, and Preston, R. J., “Myeloid Leukemia in Male RFM Mice Following Irradiation with Fission Spectrum Neutrons or Gamma Rays," Padiat. Res. 109, 165-70 (1987)

Wawrzyniak, C. J., and Popp, R. A., “Expression of the Two Adult Beta-Globin Genes in

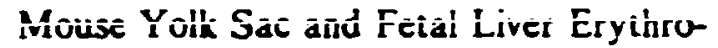
cytes," Dev. Biol. 119, 299-301 (1987)

Witschi, H. P, Godirey, G, Frome, E, and Lindenschmidt, R. C., "Pulmonary Toxicity of Cytostatic Drugs: Cell Kinetics," Fundam. Appl. Toxicol. 8, 253-62 (1987)

Witschi, H. P., Smith, L H, Frome, E. Lm Pequet-Goad, M. E, Griest, W. H., Ho, C. th, and Guerin, M. R., "Skin Tumorigenic Potential of Crude and Refined Coal Liquids and Analogous Petroleum Products," Fundam. Appl. Toxicol. 9, 297-303 (1987)

Witschi, H. P., Smith, L. H., Goad, M. E., Guerin, M. R., Griest, W. H., and Ho, C. -H., - Comparative Toxicity of Crude and Refined Coal Liquids and Analogous Petroleum Products. 1. Chronic Dermal Toxicity in Mice," pp. 144-46 in preprint of American Chemical Society Symposium on Chemical Basis for Toxicological Response in Synthetic Fuel Liquids, New York, April 13-18, 1986. Vol. 3. Am. Chem. Soc., 1986

Yim, J. J., Yoon, J., Park, Y. S., Grell, E. H., and Jacobson, K. B., “Mechanism of Suppression in Drosophila: Regulation of Tryptophan Oxygenase by the su(s) ${ }^{+}$Allele," Biochem. Genet. 25. 359-74 (1987)

\section{Central Management Offices}

Richmond, C. R., and Trimble. J. L., Biomedical and Environmental Sciences Pro. gram, ORNL/M-304, Oak Ridge Nationa! Laboratory, February, 1987

Trimble, J. L., Carter, G. R., Carter, W. C., Ellis, J. R., and Norman, V. S., Biomedical and Environmental Sciences Program Publications 1986. ORNL-6397, Oak Ridge National Laboratory, June 1987 


\section{Chemical Technology Division}

Burtis, C. A., -Advanced Technology and Its Impact on the Clinical Laboratory," Clin. Chem. 33, 352-57 (1987)

Burtis, C. A, Johnson, W. F, and W'alker, W. A., "Development of a Simple Device for Processing Whole Blood Samples into Measured Aliquots of Plasma," presented at 18th Annu. Oak Ridge Conf. Advanced Analytical Concepts for the Clinical Laboratory, Knoxville, Tenn., Apr. 17-18, 1986, Clin Chem. 32, 1642-47 (1986)

\section{Chemistry Dirision}

Baes, C. F., Jr., and Killough, G. G., "Chemical and Biological Processes in $\mathrm{CO}_{2}$-Ocean Models," presented at ORNL 6th Life Sciences Symp. Global Carbon Cycle, pp. 329-47 in The Changing Carbon Cycle: $A$ Global Analysis, Proceedings of the 6 th ORNL Life Sciences Symposium, Knoxville, Tennessee. October 31-Hovember 2, 1983. Springer-Verlag, 1986

\section{Computing and Telecommunications Division}

Ryman, J. C., Cristy, M., Eckerman, K. F., Davis, J. L., Tang, J. S., and Kert, G. D., “A Code System To Compute Radiation Dose in Human Phantoms," presented at Winter Meet. A m. Nucl. Soc., Washington, D.C., Nov. 16-20, 1986, Trans. Am. Nucl. Soc. 53, 37-38 (1986)

\section{Energy Division}

Darmstadter, J., Ayres, L. W., Ayres, R. U., Clark, W. C., Crosson, P., Graedel, T. E.,
MeGill, R., Richards, J. F., and Tarr, J. A., Impacts of World Development on Selected Characteristics of the Atmosphere: An Integrative Approach, i'olume 2. Appendices, ORNL/Sub/86-22033/1/V2, Oak Ridge National Laboratory, September 1987

\section{Engineering Physics and Mathematics Division}

Broadhead, B. L., Lillie, R. A., Pace, J. V, III, and Cacuci, D. G.,

-Sensitivity/Uncertainty Analysis for the Hiroshima Dosimetry Reevaluation Effort," presented at Conf., p. 149 in Proceedings of the American Nuclear Society Topical Conference on Theory and Practices in Radiation Protection and Shielding. Knoxville, Tennessee, April 22-24, 1987, Vol. 1, Am. Nucl. Soc., 1987

Gosslee, D. G., Sampie Size and Power Calculations for Tests on Potential Mutagens, ORNL/TM-10251, Oak Ridge National Laborataory, January 1987

Hall, M. C. G., “Application of Adjoint Sensitivity Theory to an Atmospheric General Circulation Model," J. Atmos. Sci. 43, 2644-51 (1986)

Lillie, R. A., Broadhead, B. L., Pace, J. V., III, and Cacuci, D. G.,

"Sensitivity/Uncertainty Analysis for the Nagasaki Dosimetry Reevaluation Effort." presented at Conf., pp. 139-48 in Proceedings of the American Nuclear Society Topical Conference on Theory and Practices in Radi. ation Protection and Shielding. Knoxville. Tennessee, April 22-24, 1987, Vol. 1, Arr. Nucl. Soc., 1987

Schmoyer, R. L., "Convex Sets in MinimumDistance Estimation, "Commun. Stat.-The'sr. Methods 15, 3625-35 (1986) 
Schmoyer, R. L., “Dose-Response Analysis Under Unimodality of Response-to-Dose," pp. 125-52 in Proceedings of the Conference on Advances in Order-Restricted Inference. Iowa City, Iowa, Seprember 11-!3, 1985.

Springer-Verlag, 1986

\section{Environmental Sciences Division}

Adnms, S. M. and DeAngelis, D. L., "Indirect Effects of Early Bass-Shad Interactions on Predator Population Structure and Food Web Dynamics," pp. 103-17 in Predation, University Press of New England, Hanover, N.H., 1987

Blaylock, B. G., Frank, M. L, Hoffman, F. O. and DeAngelis, D. L., "Behavior of Technetium in Freshwater Environments," presented at Seminar, pp. 79-89 in Technetium in the Environment, Proceedings of the Scientific Seminar on Behavior of Techinetium in the Environment, Cadarache, France, October 23-26, 1984, Elsevier, London, 1986

Blaylock, B. G., Hoffman, F. O, and Frank, M. L., "Tritium in the Aquatic Environment," presented at Workshop on Environmental and Human Risks of Tritium, Karlsruhe, Federal Republic of Germany, Feb 17-19, 1986, Radiat. Prot. Dosim. 16, 65-71 (1986)

Bondietti, E. A., and Brantley, J. N., "Characteristics of Chernobyl Radioactivity in Tennessee USA," Nalure 32, 313-14 (1986)

Bondietti, E. A., and Garten, C. T., Jr., -Transfer of $1-131$ and Tc-95m from Pasture to Goat Milk," presented at Seminar, pp. 339-47 in Technetium in the Environment, Proceedings of the Scientific Seminar on Behavior of Technetium in the Environment,
Cadarache, France, October 23-26, 1984. Elsevier, London, 1986

Bondietti, E. A., Papastefanou, $C_{\text {., }}$ and Rangarajan, C., “Aerodynamic Size Associations of Natural Radioactivity with Ambient Aerosols," pp. 171-91 in Radon and Its Decay Products: Occurrence, Properties, and Health Effects, Proceedings of the 191st Meeting of the American Chemical Society. New York, April 13-18, 1986, Am. Chem. Soc. Symp. Ser. 331, 1987

Broecker, W. S, and Peng, T. -H., “Carbon Cycle: 1995, Glacial to Interglacial Changes in the Operation of the Global Carbon Cycle," Radiocarbon 28, 309-27 (1986)

Broecker, W. S., and Peng, T. -H., -The Role of $\mathrm{CaCO}_{3}$ Compensation in the Glacial to Interglacial Atmospheric $\mathrm{CO}_{2}$ Change," Global Biogeochem. Cycle 1, 15-29 (1987)

Broecker, W. S., Peng, T. -H., and Ostlund, G., "The Distribution of Bomb Tritium in the Ocean," J. Geophys. Res. 91, 14331-44

(1986)

Bruce, R. R, and Luxmoore, R. J., “Water Retention: Field Methods," pp. 663-86 in Methods of Soil Analysis. Part I. Am. Soc. Agron., Madison, Wis., 1986

Casey, W. H., Bursey, C., and Olsen, C. R., - Chemical Controls on Ecology in a Coastal Wetland," EOS Trans. Am. Geophys. Union 67, 1305, 1310-11 (1986)

Coutant, C. C., "Thermal Preference: When Does an Asset Become a Liability?" Environ. Biol. Fishes 18, 161-72 (1987)

Dale, V. H., and Gardner, R. H., "Assessing Regional Impacts of Frowth Declines Using a 
Forest Succession Model," J. Environ.

Manage. 24, 83-93 (1987)

Edmonds, J. A. and Reilly, J. M.; (Ed.) Boden, T. A., and Reynolds, R. E, The IEA/CRAU Long-Term Global Energy- $\mathrm{CO}_{2}$ Model: Personal Computer Version A84PC, ORNL/CDIC-16, Oak Ridge National Laboratory, December 1986

Gardner, R. H., Milne, B. T., Turner, M. G., and O'Neill, R. V., "Neutral Models for the Analysis of Broad-Scale Landscape Pattern," Landscape Ecol. 1, 19-28 (1987)

Garten, C. T., Jr., Tucker, C. S., and Scott, T. G., -Plant Uptake of Neptunium-237 and Technetium-99 Under Field Conditions," $J$. Envirom Radioact. 4, 91-99 (1986)

Hoffman, 5. O., Gardner, R. H., and Bartell, S. M., "The Significance of Environmental Exposure Pathways for Technetium," presented at Seminar, pp. 359-76 in Technetium in the Environment, Proceedings of the Scie:-ifific Seminar on Behavior of Technetium in the Environment. Cadarache. France, October 23-26, 1984, Elsevier, London, 1986

Huston, M. A., and DeAngelis, D. L., "Size Bimodality in Monospecific Pop ulations: A Critical Review of Potential Mechanisms," Am. Nar. 129, 678-707 (1987)

Johnston, J. W., Jr., Striner, D. S., and Abner, C. H., "Design and Performance of an Exposure System for Measuring the Response of Crops to Acid Rain Gaseous Pollutants in the Field," J. Air Pollut. Control Assoc. 36, 894-99 (1986)

Kienast, F., "Radiodensitometric Tree-Ring Analysis Along Altitudinal Gradients: Some
Aiternative Procedures for De:ecting Site, Climatic, and Potential $\mathrm{CO}_{2}$ Effects on Tree Growth," pp. 452-62 in Proceedings of the International Symposium on Ecological Aspects of Tree-Ring Analysis, Palisades, New York, August 17-21, 1986, CONF. 8608144, Oak Ridge National Laboratory, 1986

King, A. W, and DeAngelis, D. L, Information for Seasonal Models of Carbon Fluxes in Agroecosysiems, ORNL/TM-9935, Oak Ridge National Laboratory, April 1987

Lindberg, S. E., "Emission and Deposition of Atmospheric Mercury Varor," presented at United Nations int. Coracil of Scientific Unions, Report 0. H.ogeochemical Cycling, Toronto, Sept. 2-7, 1984, pp. 89-106 in Lead, Mercury, Cadmium and Arsenic in the Environment, Vol. 31, Wiley, 1987

Lindberg, S. E., "Group Repor:: Mercury," pp. 17-33 in Lead, Mercury. Cadmium and Arsenic in the Environment. Vol. 21, Wiley, 1987

Lindberg, S. E., "Atmospheric Deposition and Element Cycling Research : : Walker Branch Watershed, Tennessee," pp. 114-15 in Waldschaden Forest Decline-German and U.S. American Research into Causes. Kernforschungsanlage (KFA) Juelich. Federal Republic of Germany, 1986

Lindberg, S. E., Davidson, C. I., Rondietti, E. A., Graustein, W. C., Livingston, R., Lovett, G., and Peters, J., "Surface Analysis Methods," pp. 31-48 in Proceedings of the Workshop on Dry Deposition .Measurement. Harper's Ferry. West Virginia, May 25-27. 1986. NOAA/ATDD, Oak Ridge. Tenn.. 1986 
B-10 Biomedical and Environmental Sciences Program at URNL

Lorett, G. M., and Lindberg, S. E., "Dry Deposition of Nitrate to a Deciduous Forest," Biogeochemistry 1, 137-48 (1986)

Luxmoore, R. J., Norby, R. J., and O'Neill, E. G., "Seedling Tree Responses to Nutrient Stress Under Atmospheric $\mathrm{CO}_{2}$ Enrichment," presented at 18 th IUFRO World Congress, pp. 178-83 in Proceedings of the 18th IUFRO World Congress Division 2. Ljubljana. Yugoslavia, September 8-!2, 1986, Vol. 1, IUFRO Secretariat, Vienna, 1986

Mann, L. K., "Changes in Soil Carbon Storage After Cultivation," Soil Sci. 142. 279-88 (1986)

Mattice, J. S. and Wright, L. L, "Aspects of Growth of Corbicula fluminea," Am. Malacol. Bull., Spec. Ed. 2, 167-78 (198ó)

Norby, R. J., O'Neill, E. G., H rod, W. G., and Luxmoore, R. J., "Carbon Allccation, Root Exudation, and Mycorrhizal Colonization of Pinus echinata Seedlings UnJer $\mathrm{CO}_{2}$ Enrichment," Tree Physiol. 3, 203-in (1987)

Norby, R. J., Pastor, J. and Meiillo, J. M., -Carbon-Nitrogen Interactions in $\mathrm{CO}_{2}$ Enriched White Oak: Physiological and Long-Term Perspectives," Tree Physiol. 2, 233-4l (1986)

Norby, R. J., Taylor, G. E. Jr., McLeughlin, S. B., and Gunderson, C. A., "Drought Sensitivity of Red Spruce Seedlings Afferted by Precipitation Chemistry," pp. 34-4l in Proceedings of the 9 th North American Forest Biology Workshop. Stillwater. Oklahoma, June 15-18, 1986, Soc. Am. For., 1986

Pastor, J., and Post, W. M., -Influence of Climate. Soil Moisture, and Succession on
Forest Carbon and Nitrogen Cycles," Biogeochemistry 1, 3-27 (1986)

Peng, T. -H., - The Role of the Ocean in the Atmospheric $\mathrm{CO}_{2}$ Problem," Sci. Mon. 18, 615-21 (1986)

Peng, T. -H., and Freyer, H. D., "Revised Estimates of Atmospheric $\mathrm{CO}_{2}$ Variations Based on the Tree-Ring ${ }^{13} \mathrm{C}$ Record," pp. 151-59 in The Changing Carbon Cycle: $A$ Global Analysis, Proceedings of the $6 \mathrm{th}$ ORNL Life Sciences Symposium. Knuxville. Tennessee, October 31-November 2, 1983. Springer-Verlag, New York, 1986

Shugart, L. R, McCarthy, J. F, Jimenez, B., and Danieks, J., "Analysis of Adduct Formation in the Bluegill Sunfish (Lepomis macrochirus) Between Benzo[a]pyrer.e and DNA of the Liver and Hemoglobin of the Erythrocyte," Aquat. Toxicol. 9, 319-25 (1987)

Singh, B. R. and Johnson, D. W., "Sulfate Content and Adsorption in Soils of Two Forest Watersheds in Southern Norway," Water Air Soil Pollut. 31, 847-56 (1986)

Solomon. A. M., "Comparison of Taxon Calibrations, Modern Analogue Techniques, and Forest-Stand Simulation Models for the Quantitative P.econstruction of Past Vegeta. tion: A Critıque," Earth Surf. Processes Landforms 11, 681-85 (1986)

Southworth, G. R., -Movement of Radiotracer Metal Cations Through a Forest Soil Column," Environ. Int. 13, 197-201 (1997)

Southworth, G. R., Watson, K. W., and Keller, J. L., "Comparison of Models That Describe the Transport of Organic Compounds in Macroporous Soil," Environ. Toxicol. Chem. 6. 251-57 (1987) 
Stewart, A. J., “Responses of Stream Algae to Grazing Minnows and Nutrients: A Field Test for Interactions," Oecologia 72, 1-7 (198i)

Stewart, A. J., and Wetzeh, R. G., "Cryptophytes and Other Microflagellates as Couplers in Planktonic Community Dynamics," Arch. Hydrobiol. 106, 1-19 (1986)

Takemoto, B. K., Shriner, D. S, and Johnston, J. W, Jr., "Physiological Responses of Soybean (Glycine max L. Merr) to Simulated Acid Rain and Ambient Ozone in the Field," Water Air Soil Pollut. 33, 373-84 (1987)

Tripathi, V. S., “An Algorithm and a FORTRAN Program (CHEMEQUIL-2) for Calculation of Complex Equilibria," Talanta 33, 10i 5-20 (1986)

Tripathi, V. S, Yeh, G. T., and Siegel, M. D., "A Benchmark in Portable FORTRAN: Speeds of CPU and In-Memory DataTransfer Operations for Hydrogenchemical Models," Comput. Geosci. 13, 405-08 (1987)

Health and Safety Research Division

Alak, A. M., and Vo-Dinh, T., "SurfaceEnhanced Raman Spectrometry of Organophosphorous Chemical Agents," Anal. Chem. 59, 2149-53 (1987)

Ambrose, K. R, Butler, T. A., Callahan, A. P, and Ferren, L A., In Vivo Toxicity of Arsenic Trioxide for Human Cells in Diffusion Chambers, ORNL/TM-10231, Oak Ridge National Laboratory, December 1986

Ambrose, K. R., Uwen, B. A., Coodman, M. M., and Knapp, F. F., Jr., "Evaluation of the Metabolism in Rat Heares of Two New Radioiodinated 3-Methyl-Branched Fatty
Acid Myocardial Imaging Agents," Eur. J. Nucl. Med. 12, 486-91 (1987)

Arakswa, E T. "Experimental Studies of Transition Radiation and Optical Bremsstrablung," pp. $31-42$ in Proceedings of the Werner Brandt Workshop on Penetration Phenomena: Photon Emission from Irradiated Solids, Oak Ridge. Tennessee, April 15-16, 1985, CONF-850484, Oak Ridge National Laboratory, 1986

Arakawa, E. T., Emerson, L. C., Juan, S. I., Ashley, J. C., and Williams, M. W., "The Optical Properties of Adenine from 1.8 to 80 eV," Photochem. Photobiol. 44, 349-53 (1986)

Blazewicz, P. R., Payne, M. G., Garrett, W. R, and Miller, J. C., "Laser-Induced ThirdHarmonic Generation in Forbidden Regions," Phys. Rev. A 34, 5171-74 (1986)

Blazewicz, P. R., Stockdale, J. A. D., Miller, J. C., Efthimiopoulos, T, and Fotakis, C., -Four-Photon Excitation of Even-Parity Rydberg States in Krypton and Xenon," Phys. Rev. A 35, 1092-98 (1987)

Blazewicz, P. R., Tang, X, Compton, R. N., and Stockdale, J. A. D., "Photoelectron Angular Distributions from Resonantly Enhanced Multiphoton Ionization of Xenon via $t^{\prime}$ : $6 s[3 / 2]_{1}^{0}$ and $6 s^{\circ}[1 / 2]_{1}^{0}$ States: Experiment and Theory," J. Opt. Soc. Am. B 4. 770-74 (1987)

Bloemer, M. J., Mantovani, J. G., Goudonnet, J. P , James, D. R., Warmack, R. J., and Ferrell. 1. L., "Observation of Driven SurfacePlasmon Modes in Metal Particulates Above Tunnel Junctions," Phys. Rev. B 35. 5947-54 (1987) 


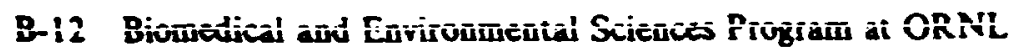

Bolch, W. E., Turner, J. E. and Hamm, R. N., An Algorithm for Unfolding Neutron Dose and Dose Equivalent from Digitized Recoil-Particle Tracks, ORNL/TM-10168, Oak Ridge National Laboratory, October 1986.

Bolch, W. E., Turner, J. E, Hamm, R. N. Hurst, G. S, and Wright, H. A., "A Method of Obtaining Neutron Dose and Dose Equivalent from Digital Measurements and Analysis of Recoil-Particle Tracks," Health Phys. 53, 241-53 (1987)

Buncick, M. C., Warmack, R. J., and Ferrell, T. L., "Optical Absorbance of Silver Ellipsoidal Particles," J. Opt. Soc. Am. B 4, 927-33 (1987)

Callcott, T. A., Tsang, K. Lo, Zhang, C. Hon Ederer, D. Lo, and Arakawa, E. T., "A HighEfficiency Soft X-Ray Emission Spectrometer for Use with Synchrotron Radiation Excit:tion," Rev. Sci. Instrum. 57, 2680-90 (1986)

Chen, C. H., and McCann, M. P., "Threshold of F-Center Formation of Alkali Halide Crystals by Two-Phuton Absorption," Opt. Commun. 60, 296-97 (1986)

Chen, C. H., McCann, M. P., and Wang, J. C., -Room-Temperature Two-Photon Induced Luminescence in Pure CsI," Solid State Commun. 61, 559-62 (1987)

Christophoroc, L. G., Hunter, S. R., Carter, J. G., and Spyron, S. M., "Effects of Temperature on Dissociative and Nondissociative Electron Attachment," pp. 303-8 in Proceedings of the Joint Symposium on Swarm Studies and Inelastic Electron Molecule Collisions. Tahoe City, California, July 19-23, 1989. Springer-Verlag, New York, 1986.
Christophorom, L. G, Hunter, S. R., Pineaduwage, L. A. Carter, J. G., Christodoolides, A. An and Spyrom, S. M., "Optically Enhanced Electron Attachment," Prys. Rev. Letr. 58, 1316-19 (1987)

Cristy, M., and Eckerman, K. F., Specific Absorbed Fractions of Energy at Various Ages from Internal Photon Sources. $I$. Methods, ORNL/TM-8381/V1, Oak Ridge National Laboratory, April 1987

Cristy, M, and Eckerman, K. F., Specific Absorbed Fractions of Energy at Various Ages from Internal Photon Sources. II. OneYear-Old, ORNL/TM-8381/V2, Oak Ridge National Laboratory, April 1987

Cristy, M., and Eckerman, K. F., Specific Absorbed Fractions of Energy at Various Ages from Internal Photon Sources. III. Five-Year-Old, ORNL/TM-8381/V3, Oak Ridge National Laboratory, April 1987

Cristy, M., and Eckerman, K. F., Specific Absorbed Fractions of Energy at Various Ages from Internal Photon Sources. IV. TenYear-Old, ORNL/TM-8381/V4, Oak Ridge National Laboratory, April 1987

Cristy, M., and Eckerman, K. F., Specific Absorbed Fractions of Energy at Various Ages from Internal Phoron Sources. $V$. Fifteen-Year-Old Male and Adult Female. ORNL/TM.8381/V5, Oak Ridge National Laboratory, April 1987

Cristy, M., and Eckerman, K. F., Specific Absorbed Fractions of Energy at Various Ages from Internal Photon Sources. VI. Newborn, ORNL/TM-8381/V6. Oak Ridge National Laboratory, April 1987

Cristy, M., and Eckerman, K. F., Specific Absorbed Fractions of Energy at Various 
Ages from Internal Photon Sources. VII. Adult Male, ORNL/TM-8381/V7, Oak Ridge National Laboratory, April 1987

Datskos, P. G. and Christophoron, L. G., -Variation of the Electron Attachment to n- $\mathrm{C}_{4} \mathrm{~F}_{10}$ with Temperature," J. Chem. Phys. 86, 1982-90 (1987)

Dodhy, A., Stockdale, J. A. D., Compton, R. N., Tang, $X_{\text {., Lambropoulos, }} \mathrm{P}_{\text {, and Lyras, }}$ A., Two-Photon Resonant Three-Photon Ionization of the $\mathrm{nd}^{2} \mathrm{D}$ States of Cesium, Rubidium, and Sodium: Photoelectron Angular Distributions," Phys. Rev. A 35, 2878-91 (1987)

Dodezak, R., Schmoliner, R, Angelberger, P., Knapp, F. F., Jr, and Goodman, M. M., "Structurally Modified Fatty Acids-Clinical Potential as Tracers of Metabolism," Eur. J. Nucl. Med. 12, S45-S48 (1986)

Echenique, P. M., Gras-Marti, A., Manson, J. R., and Ritchie, R. H., "The Image Potential for a Tunneling Electron," Phys. Rev. B 35, 7357-64 (1987)

Eckerman, K. F.; (ed.) Leggett, R. W., and Warten, B. P., Age-Specific Models for Evaluating Dose and Risk from Internal Exposures to Radionuclides. Report of Current Work of the Metabolism and Dosimetry Research Group. July l. 1985-June 30, 1987, ORNL/TM-10080. Oak Ridge National Laboratcry, September 1987

Eklued, P. C., Hoffman, D. M., Delong, L. E., Arakaw2, E. T., Smith, J. L., and Fisk, Z., "Optical Properies of $\mathrm{UBe}_{13}, \mathrm{CeBe}_{13}$, and ThBe $13, "$ Phys. Rev. B 35, 4250-57 (1987)

Faidas, H., and Christophorou, L. G., “Multiphoton Ionization of Fluoranthene in
Tetramethylsilane," J. Chem. Phys. 86, 2505-9 (1987)

Ferrell, W. R, Payne, M. G, and Garrett, W. R., Determination of Optical Constants in Noble Gases Through Multiphoton Ionization Measurements," Phys. Rev. A 35, 5020-31 (1987)

Ferrell, W. R, Payne, M. G, and Garrett, W. R., "Resonance Broadening and Shifting of Spectral Lines in Xenon and Krypton," Phys. Rev. A 36, 81-89 (1987)

Fung, K. W, Matthews, T. G., Tromberg, B. J., and Hawthorne, A. R., "Impact of Indoor Environmental Parameters on Formaldehyde Concentrations in Unoccupied Research Houses," J. Air Pollut. Control Assoc. 36, 1244-49 (1986)

Garreth, W. R., Headerson, S. D., and Payne, M. G., "Observation of Laser-induced Collisional Energy Transfer in Xe-Ar Mixtures," J. Opt. Soc. Am. B 4, 133-37 (1987)

Garreth, W. R., Henderson, S. D., and Payne, M. G., "Two-Color Interference Effect Involving Three-Photon Excitation and Four-Wave Mixing Prucesses," Phys. Rev. A 34, 3463-65 (1986)

Garrett, W. R., Henderson, S. D., and Payne. M. G., "Multiphoton Ionization Spectra and Tunable Fifth Harmonic Production Near Five-Photon Resonances in Xe and Ar," Phys. Rev. A 35, 5032-37 (1987)

Goudonnet, J. P., Inagaki, T., Arakawz, E. T., and Ferrell, T. L., Angular and Polarization Dependence of Surface-Enhanced Raman Scattering in Attenuated-Total-Reflection Geometry." Phys. Rev. B 36. 917-21 (1987) 
B-14 Biomedical and Environmental Sciences Program at ORNL

Hawthorne, A. R., and Matthews, T. G., - Models for Estimating Organic Emissions from Building Materials: Formaldehyde Example," Atmos. Environ 21, 419-24 (1986)

Holton, G. A, Travis, C. Ca Etrier, E Lo Cook, S. C., O'Donnell, F. R., Hetrick, D. Man

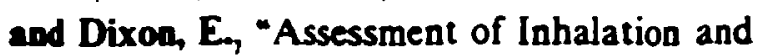
Ingestion Population Exposures from Incinerated Hazardous Wastes," Environ. Int. 12. 533-40 (1986)

Hunter, S. R., Evaluation of a Digital Optical Ionizing Radiation Particle Track Detector, ORNL/TM-10421, Oak Ridge National Laboratory, June 1987

Hunter, S. R., Carter, J. G, and Christophoron, L G., "Electron Attachment and Ionization Processes in $C F_{4}, C_{2} F_{6}, C_{3} F_{8}$, and n- $\mathrm{C}_{4} \mathrm{~F}_{10}, "$ J. Chem. Phys. 86, 693-703 (1987)

Inagaki, T., Goudonnet, J. P., Royer, $P_{\text {, a a }}$ Arakawa, E. T., "Optical Properties of Silver Island Films in the Attenuated-TotalReflection Geometry," Appl. Opt. 25, 3635-39 (1986)

Judish, J. P., and Wunderlich, R. K., “Measurement of the Diffusion Coefficient of $\mathrm{Li}$ in Argon," J, Phys. B: At. Mol. Phys. 20. 2317-25 (1987)

Khare, B. No, Sagan, Co, Ogino, H., Nagy, B. Er, C., Schram, K. H., and Arakawa, E. T.. "Amino Acids Derived from Titan Tholins," Icarus 68, 176-84 (1986)

Klots, C. E., "Temperatures of Evaporating Ciusters." Valure 327, 222-23 (1987)

Klots, C. E., "The Evaporative Ensemble," $Z$. Phys. D. Aloms, Mol. Clusters 5, 83-89 (1987)
Klots, C. E., "On the Energy Dependence of Unimolecular Rate Constants," $J$. Phys.

Chem. 90, 6063 (1986)

Klots, C. E, "Enthalpy Conversion in SonicNozzle Expansions," Chem. Phys. Lett. 137. 353-54 (1987)

Kmapp, F. F, Jr, Ambrose, K. R, and Goodman, M. M., "New Radioiodinated MethylBranched Fatty Acids for Cardiac Studies," presented at Symp. Assessment of Myocardial Metabolism by Cardiac Imaging, Vienna, Oct. 26, 1985, Eur. J. Nucl. Med. 12. S39-S44 (1986)

Kmapp, F. F, Jr, Ambrose, K. R, Goodman, M. M., and Srivastava, P. C., Nuclear Medicine Progress Report for Quarter Ending March 31, 1986, ORNL/TM-10082, Oak Ridge National Laboratory, October 1986

Knapp, F. F, Jr, Ambrose, K. R., Goodman, M. M., and Srivastara, P. C., Nuclear Medi. cine Progress Report for Quarter Ending June 30, 1986, ORNL/TM-10238, Oak Ridge National Laboratory, December 1986

Knapp, F. F., Jr., Ambrose, K. R., Goodman, M. M., and Srivastava, P. C., Vuclear Medi. cine Progress Report for Quarter Ending Septermber 30, 1986, ORNL/TM-10294, Oak Ridge National Laboratory, February 1987

Knapp, F. F., Jr, Ambrose, K. R., Goodman. M. M., and Srivastara, P. C., Nuclear Medicine Progress Report for Quarter Ending December 31. 1986, ORNL/TM-10377. Oak Ridge National Laboratory, June 1987

Knapp, F. F., Jr., Ambrose, K. R., and Srivastava, P. C., Vuclear Medicine Progress Report for Quarter Ending March 31. 1987. ORNL/TM-10441. Oak Ridge National Laboratory. August 1987 
Knapp, F. F, Jr, Goodman, M. M., Ambrose, K. R., Som, P., Brill, A. B., Yamamoto, K, Kubota, K, Yonekura, Y, Dodezak, R. Angelberger, $P_{\text {, and }}$ Schmoliner, $R_{\text {., - The }}$ Development of Radioiodinated-MethylBranched Fatty Acids for Evaluation of Myocardial Disease by Single Photon Techniques," pp. 159-202 in Noninvasive Imaging of Cardiac Metabolism, Martinus Nijhoff Medical Publ., Amsterdam, 1987

Kmapp, F. F, Jr, and Srivastava, P. C., -Potential New Approaches for the Development of Brain Imaging Agents for SinglePhoton Applications," pp. 71-74 in Proceedings of the Workshop on Amphetamines and pH-Shift Agents for Brain Imaging, Basic Research and Clinical Results, Bonn. Federal Republic of Germany, October 12-13. 1984. Walter de Gruyton and Co., Berlin and New York. 1986

Krale, T. J., Compton, R. N. Alton, G. D, Thompson, J. S., and Pezg, D. J., "Autodetachment Spectroscopy of Metastable Negative Ions," Nucl. Instrum. Methods Phys. Res. B 24/25, 325-28 (1987)

Leggett, R. W., and Eckerman, K. F., “A Method for Estimating the Systemic Burden of Plutonium from Urinalyses," Health Phys. 52, 337-46 (1987)

Lehmann, B. E., Loosli, H. H, Oeschger, $H_{n}$ Rauber, D. Hurst, G. S., Allman, S. L., Chen, C. H., Kramer, S. D., Thonnard, N. and Willis, R. D., "Laser Resonance Ionization Mass Spectrometry for Krypton-81 Analysis," Radiocarbon 28, 223-28 (1986)

Martin, C., Arakawa, E. T., Callcott, T. A., and Warmack, R. J., -Attenuation Lengths of Low-Energy Electrons in Free-Stanu'ing Cur. bon Films," J. Electron Spectrosc. Relat. Phenom. 42, 171-75 (1987)
Matthews, T. G., “Environmental Chamber Test Methodology for Characterizing Organic Vapors from Solid Emission Sources," presented at EPA Symp. Characterization of Contarninant Emissions from Indoor Sources, Research Triangle Park, N.C., May 13-15, 1985, Atmos. Environ 21, 321-29 (1987)

McCann, M. P., Chen, C. H, and Kramer, S. D., "Ultraviolet Laser Beam Monitor Using Alkali Halide Crystals," Opt. Eng. 25, i 177-78 (1986)

MeCann, M. P., Chen, C. H, and Payne, M. G., Energy Level Determination Using TwoPhoton (Vacuum Ultraviolet and Visible) Resonance Spectroscopy," Appl. Spectrosc. 41, 399-401 (1987)

MeCann, M. P., Chen, C. H., and Payne, M. G., "Vacuum Ultraviolet Generation and Use in Two-Photon Resonance Spectroscopy," Chem. Phys. Lett. 138, 250-56 (1987)

Miller, J. C., "Multiphoton Ionization of JetCooled lodine," J. Phys. Chem. 91, 2589-92 (1987)

Miller, J. C., -Multiphoton Spectroscopy of $\mathrm{X}$-NO $\left(\mathrm{X}=\mathrm{Kr}, \mathrm{Xe}, \mathrm{CH}_{4}\right)$ van der Waals Molecules," J. Chem. Phys. 86, 3166-71 (1987)

Oyan, R., and Sims, C. S., -Radiation Dose from HPRR Gamma Rays," Radiat. Prot. Dosim. 16, 213-17 (1986)

Paype, M. G., -Vacuum Ultraviolet Light Generation Applications to Resonance Ionization Spectroscopy," pp. 59-66 om Proceedings of the 3rd International Symposium on Resonance Ionization and Its Applications. Swansea. Wales. September 7-12. 1986. Inst. Phys. Conf. Ser. 84. 1987 
Proctor, M. J., Stockdale, J. A. D. Efthimioponlos, T., and Fotakis, C., *ThirdHarmonic Generation and Ionization Processes in Kr," Chem. Phys. Letr. 137, 223-25 (1987)

Reske, S. N, Knapp, F. F., Jr., and Winkler, C., Metabolic Imaging of the Myocardium with Radioiodinated Aromatic Free Fatty Acids. I. Experimental Basis," Am. J. Phys. iol. Imaging 1, 214-29 (1986)

Royer, P., Goudounet, J. P., Warmack, R. J, and Ferrell, T. L., "Substrate Effects on Surface-Plasmon Spectra in Metal-Island Films," Phys. Rev. B 35, 3753-59 (1987)

Russell, B. K., Mantorani, J. Ga, Anderson, V. E, Warmack, R. J., and Ferrell, T. L., - Experimental Test of the Mie Theory for Microlithographically Produced Silver Spheres," Phys. Rev. B 35, 2151-54 (1987)

Sims, C. S., “New Personnel Dosimeter Performance Test Programs in the United States," pp. 183-88 in Personnel Radiation Dosimetry, IAEA-TECDOC-402, Vienna, 1987

Sims, C. S., $\$ 1986$ Reference Neutron Dosimetry for the Health Physics Research Reactor," Radiat. Prot. Dosim. 15, 41-44 (1986)

Sims, C. S., and Ragan, G. E., Health Physics Research Reactor Reference Dosimetry, ORNL-6240, Oak Ridge National Laboratory. June 1987

Siskel, R. L., Sims, C. S., and Swaja, R., “A Comparative Study of Three Types of Civil Defense High-Range Pocket Dosimeters," Trans. Am. Nucl. Soc. 54, 304 (1987)
Sols, F., and Ritchie, R. H., -Self-Energy of an Electron in a Gap Between Two Metais and Near a Metallic Slab," Phys. Rev. B 35 , 9314-17 (1987)

Sols, F, and Ritchie, R. H., "The Interaction Between an Electron and the Polarization Modes of a Metal-Insulator Interface," Solid State Commun 63, 245-49 (1987)

Stockdale, J. A. D., "Dissociation of Internally Excited UF 6 Ions in Collision with Aigon Atoms," Chem. Phys. Lett. 137, 399-402 (1987)

Stockdale, J. A. D, Efthimiopoulos, T, Fotakis, C, and Blazewicz, P. R.. *Multiphoton Ionization of Krypton and Xenon: $A n$ Investigation of the Autoionizing Region Between $P_{1 / 2}$ and $P_{3 / 2}$ Thresholds," pp. 236-38 in High Intensily Laser Processes. Vol. 664, Proc. Photo-Opt. Instrum. Eng. Inst. Symp., Quebec City, June 2-6. 1986. Soc. Photo-Opt. Instrum. Eng., Bellingham. Wash., 1986

Sung, C. C, Mo, K., and Ritchie, R. H., "Dynamical Corrections to the Binding Energy of a Solvated Electron," Chem. Phys. Letl. 136, 9-12 (1987)

Suter, G. W, Kallir, A. J., Wild, L. P., and Vo-Dinh, T., "Hydrogen-Bonding Properties of a Room-Temperature Phosphorescence Cellulose Substrate,"J. Phys. Chem. 90. 494!-45 (1986)

Suter, G. W. Kallir, A. J., Wild, C. P, and Vo-Dinh, T., -The External Heavy-Effect in Room Temperature Phosphorescence Spec. troscopy," Anal. Chem. 59. 1644-46 (1987)

Swaja. R. E., and Oyan, R., -Uncertainties Associated with Using Quick-Sort Techniques 
To Estimate Neutron Doses Following Criticality Accidents," Health Phys. 50, 28-29 (1986)

Swaja, R. E, and Scofield, P. A., "Factors Affecting the Gamma Response of TLD-700 Chips in Mixed-Radiation Fields," Radiat. Prot. Manage. 3, 44-52 (1986)

Swaja, R. E, Weng, P. S., Sims, C. S., and Yeh, S. H., Summary and Analysis of 1986 Personnel Dosimetry Intercomparison Study, ORNL-6378, Oak Ridge National Laboratory, April 1987

Travis, C. C., Holton, G. A., Etmier, E. L, Cook, S. C, O'Donnell, F. R., Hetrick, D. M., and Dixon, E., "Potential Health Risk of Hazardous Waste Incineration," J. Hazardous Mater. 14, 309-20 (1987)

Uziel, M., Ward, R. J., and Vo-Dinh, T., -Synchronous Fluorescence Measurement of BaP Metabolites in Human and Animal Urine," Anal. Lett. 20, 761-76 (1987)

Varma, M., Varma, R. S, Kabalka, G. W, Srivastava, P. C., and Knapp, F. F., Jr., "The Tosylation of Alcohols," J. Org. Chem. 51, 2386-88 (1986)

Vo-Dinh, T., "Characterization of Surface Contaminants by Luminescence Using Ultraviolet Excitation," pp. 103-22 in Treatise on Clear Surface Technology. Vol. 1, Plenum, 1987

Vo-Dinh, T., and Alak, A., "Enhanced RoomTemperature Phosphorescence of Anthracene on Cyclodextrin-Treated Filter Paper," Appl. Spectrosc. 41, 963-66 (1987)

Vo-Dinh, T., Suter, G. W., Kallir, A. J., and Wild, U. P. "Fluorescence Line-Narrowing
Spectrometry of Polycyclic Compounds on Filter Paper Substrates," Anal. Chem. 58, 3135-39 (1986)

Vo-Dinh, T., and Uziel, M., "Laser-Induced Room-Temperature Phosphorescence Detection of Benzo(a)pyrene-DNA Adducts," Anal. Chem. 59, 1093-95 (1987)

Vo-Dinh, T., Uziel, M., and Morrison, A. L, -Surface-Enhanced Raman Analysis of Benzo[a]pyrene-DNA Adducts of SilverCoated Cellulose Substrates," Appl. Spectrosc. 41, 605-10 (1987)

Walsh, P. J., Health and Safety Research Division Progress Report for the Period October 1. 1985-March 31, 1987, ORNL. 6389. Oak Ridge National Laboratory, September 1987

Warmack, R. J., Ferrell, T. L., and Little, J. W., "Radiative Decay of Surface Plasmons," pp. 71-78 in Proceedings of the Werner Brandt Workshop on Penetration Phenomena: Photon Emission from Irradiated Solids, Oak Ridge, Tennessee, April I5-16. 1985. CONF-850484, Oak Ridge National Laboratory, 1986

Williams, L. R., and Leggetr, R. W., "The Distribution of Intracellular Alkali Metals in Refereice Man," Phys. Med. Biol. 32. 173-90 (1987)

Wunderlich, R., Payne, M. G., and Garrett. W. R., "RIS and Competing Processes in High Concentration Atomic Vapors," presented at Symp., pp. 269-74 in Proceedings of the 3rd International Symposium on Resonance lonization Spectroscopy and Its Applications. Swansea. Wales. September 7-12, 1986. Inst. Phys. Conf. Ser. 84. 1987 